CARLOS JOSÉ TEIXEIRA DE TOLEDO

\title{
DESENHO JURÍDICO-INSTITUCIONAL DE POLÍTICAS PÚBLICAS: A CARREIRA DOCENTE COMO ELEMENTO ESTRUTURAL DA EDUCAÇÃO BÁSICA
}

Tese de Doutorado

Orientadora: Professora Associada Dra. Maria Paula Dallari Bucci

UNIVERSIDADE DE SÃO PAULO

FACULDADE DE DIREITO

São Paulo - SP

2019 
CARLOS JOSÉ TEIXEIRA DE TOLEDO

\section{DESENHO JURÍDICO-INSTITUCIONAL DE POLÍTICAS PÚBLICAS: A CARREIRA DOCENTE COMO ELEMENTO ESTRUTURAL DA EDUCAÇÃO BÁSICA}

Tese apresentada à Banca Examinadora do Programa de PósGraduação em Direito, da Faculdade de Direito da Universidade de São Paulo, como exigência parcial para obtenção do título de Doutor em Direito, na área de concentração Direito do Estad.

Orientadora: Professora Associada Dra. Maria Paula Dallari Bucci

UNIVERSIDADE DE SÃO PAULO

FACULDADE DE DIREITO

São Paulo - SP

2019 
Autorizo a reprodução e divulgação total ou parcial deste trabalho, por qualquer meio convencional ou eletrônico, para fins de estudo e pesquisa, desde que citada a fonte.

Catalogação na Publicação

Serviço de Biblioteca e Documentação

Faculdade de Filosofia, Letras e Ciências Humanas da Universidade de São Paulo

$\mathrm{T} 647 \mathrm{~d}$

Toledo, Carlos José Teixeira de

DESENHO JURIDICO-INSTITUCIONAL DE POLÍTICAS

PÚBLICAS: A CARREIRA DOCENTE COMO ELEMENTO ESTRUTURAL

DA EDUCAÇÃO BÁSICA / Carlos José Teixeira de Toledo

; orientadora Maria Paula Dallari Bucci. - São Paulo, 2019.

$296 \mathrm{f}$

Tese (Doutorado) - Programa de Pós-Graduação Humanidades, Direitos e Outras Legitimidades da Universidade de São Paulo. Área de concentração: Humanidades, Direitos e Outras Legitimidades.

1. Teoria do Estado. 2. Políticas públicas. 3. Direito público. 4. Política educacional. 5. Política de recursos humanos. I. Bucci, Maria Paula Dallari orient. II. Título. 
Nome: TOLEDO, Carlos José Teixeira de

Título: Desenho jurídico-institucional de políticas públicas: a carreira docente como elemento estrutural da educação básica.

Tese apresentada à Banca Examinadora do Programa de PósGraduação em Direito, da Faculdade de Direito da Universidade de São Paulo, como exigência parcial para obtenção do título de Doutor em Direito, na área de concentração Direito do Estado, sob a orientação da Orientadora: Professora Associada Dra. Maria Paula Dallari Bucci

Aprovado em:

Banca Examinadora:

$\operatorname{Prof}(\mathrm{a}) . \operatorname{Dr}(\mathrm{a})$.

Instituição:

Julgamento:

$\operatorname{Prof}(\mathrm{a}) . \operatorname{Dr}(\mathrm{a})$.

Instituição:

Julgamento:

Prof(a). Dr(a).

Instituição:

Julgamento:

$\operatorname{Prof}(a) . \operatorname{Dr}(a)$.

Instituição:

Julgamento:

Prof(a). Dr(a).

Instituição:

Julgamento: 
A Norma, mãe e educadora (in memoriam).

E a Luísa, luz dos meus dias. 


\section{AGRADECIMENTOS}

"Na curva perigosa dos cinquenta / derrapei neste amor", diz o famoso verso drummondiano. No meu caso, deu-se o mesmo, mas se tratava de amor antigo, que estava há mais de vinte anos como brasa dormida, mas que foi reavivado graças ao apoio de pessoas generosas que me cercam. $\mathrm{O}$ amor ao conhecimento é o liame que compartilhamos e que se torna uma chama mais brilhante, à medida que a escuridão cresce lá fora.

À Professora Maria Paula Dallari Bucci, minha gratidão pela acolhida dada a um filho pródigo, que retorna à sua Alma Mater. Ao ler sua obra Direito Administrativo e Políticas Públicas, antes mesmo de conhecê-la, percebi que havia um olhar novo na Academia, percepção que se reforçou ao estudar seu Fundamentos para uma Teoria Jurídicas das Políticas Públicas. Sem sua orientação dedicada e os ensinamentos colhidos ao longo desses anos de convívio, este trabalho não teria sido ultimado. Agradeço-lhe sobretudo a paciência com um orientando que, pelas circunstâncias de vida, nem sempre foi capaz de atender aos compromissos acadêmicos.

Agradeço também aos demais mestres que contribuíram para a minha formação ao longo destes três anos. Aos professores Fernando Menezes, Nina Stocco Ranieri, Vitor Rhein Schirato, Jens Peter Schneider, Marcos Augusto Perez, José Maurício Conti, Rodrigo Pagani de Souza, Conrado Hübner Mendes, Murilo Gaspardo, Ronaldo Porto Macedo Jr. e Wagner Pralon Mancuso, meu reconhecimento pelo saber compartilhado, no exercício da mais nobre das profissões.

Um agradecimento especial a Patrícia Ulson Pizarro Werner, exemplo de vida acadêmica e profissional e estimadíssima amiga. Sem seu generoso auxílio e constante estímulo, sequer teria ousado o reingresso nas fileiras escolares.

Outros amigos foram especialmente importantes, pela disposição de contribuir com sugestões, bibliografia, questionamentos ou simplesmente com a escuta paciente. Rendo minha admiração a Marcello Garcia, Antonio Roberto Sanches Júnior, Paulo Sena Martins e Paulo Cesar Vaz Guimarães, amigos cuja honestidade intelectual serviu de valiosa bússola nesse trajeto.

$\mathrm{Na}$ minha trajetória docente, encontrei gestores acadêmicos genuinamente vocacionados e que generosamente me estimularam a prosseguir nos estudos: meu reconhecimento a Carlos Eduardo de Abreu Boucault, Márcia Walquíria Batista dos Santos e Fernando Herren Aguillar.

Meu reconhecimento também a todos os colegas do Programa de Pós-Graduação da Faculdade de Direito, que dividiram comigo as inquietações típicas da vida estudantil. Deixo de nominá-los, por muito numerosos, mas registro aqui o prazer da camaradagem acadêmica, na Casa onde mora a amizade e a alegria. 
Esse trabalho também não seria possível sem o estímulo institucional da Procuradoria Geral do Estado, por meio de seu Centro de Estudos e de seus programas de auxílio ao aperfeiçoamento dos Procuradores do Estado. À bibliotecária Hercília Maria de Oliveira Matos, agradeço a ajuda sempre competente na busca de material bibliográfico, para enriquecimento do trabalho.

Outro tipo de estímulo, mais aprazível, possibilitou períodos de ócio produtivo para a pesquisa: registro meu agradecimento à família Correali, pela hospitalidade recorrente e pela amizade constante.

Sem tranquilidade doméstica, nenhum trabalho intelectual é possível. Minha gratidão a Maria Helena Batista, zeloso anjo da guarda que acompanhou minha mãe até seu último dia e que agora olha por meu pai, com igual dedicação.

Minha gratidão eterna a Carlos Maria de Toledo, meu pai, que me ensinou o sentido da Justiça e me fez compreender o valor inestimável do conhecimento, único patrimônio realmente duradouro.

Por último, minha homenagem a minha mulher, Maria Elena Roman de Oliveira Toledo, mãe e educadora admirável. Seu exemplo de dedicação ao magistério sempre foi uma inspiração para mim. Sem seu afeto e paciência, essa jornada não teria chegado ao seu termo. 
[...] é tempo de reconhecer que não há empreendimento maior e mais indeclinável para uma democracia - mesmo uma simples democracia política que não seja uma burla ou uma fraude grosseira - que educar toda uma nação, ou todo o povo para ser efetivamente a nação.

ANÍSIO TEIXEIRA, 1953. 
TOLEDO, Carlos José Teixeira de. Desenho jurídico-institucional de políticas públicas: a carreira docente como elemento estrutural da educação básica. Tese (Doutorado em Direito). Programa de Pós-graduação da Faculdade de Direito da Universidade de São Paulo, São Paulo, 2019.

\section{RESUMO}

Dentre os múltiplos entraves à melhoria do ensino nas escolas públicas do país, um dos fatores mais persistentes é a desvalorização da profissão docente, tendência que, com raras exceções geográficas e temporais, perpassa toda a história nacional. Adotando de forma combinada as ferramentas de análise de políticas públicas e da ciência jurídica, nossa tese busca compreender a trajetória do magistério público, por meio do estudo das políticas docentes, de suas formulações legislativas e de seu contexto histórico. A partir de tal compreensão histórica, é possível entender as características institucionais do Estado Brasileiro e quais os fatores que dificultam o cumprimento dos comandos constitucionais voltados à valorização docente, especialmente os contidos nos incisos V (planos de carreira e remuneração) e VIII (piso salarial nacional profissional) do art. 206 do Texto Constitucional. Atualmente, o Plano Nacional de Educação de 2014 estabelece metas concretas nesse sentido - Metas 17 e 18 - todavia seriamente comprometidas em sua realização. $\mathrm{O}$ avanço nessas metas, conforme pudemos constatar, passa por uma compreensão da dinâmica federativa e dos obstáculos jurídicos, políticos e financeiros existentes para o estabelecimento de uma política nacional voltada à valorização da carreira docente. Dadas as evidências sobre a insuficiência das políticas regulatórias e indutivas já praticadas e o irrealismo de propostas de cunho excessivamente centralizador, concluímos pela necessidade de favorecer soluções que reforcem o regime de colaboração entre os entes da federação, mediante atuação indutiva e coordenadora da União, Somente por meio de políticas pactuadas e pela efetiva implantação de um Sistema Nacional de Educação as desigualdades horizontais e verticais presentes na federação brasileira podem ser superadas, inclusive no que tange às discrepâncias relativas ao regime de carreira e remuneração do magistério público.

Palavras-chave: Política docente. Educação. Carreira do magistério. Política educacional. 
TOLEDO, Carlos José Teixeira de. Legal-institutional design of public policies: the teaching career as a structural element of basic education. Tese (Doutorado em Direito). Programa de Pós-graduação da Faculdade de Direito da Universidade de São Paulo, São Paulo, 2019.

\begin{abstract}
Among the many obstacles to the improvement of education in public schools in Brazil, one of the most persistent is the devaluation of the teacher as a professional. That tendency, with rare geographic and temporal exceptions, runs throughout national history. By adopting the analysis of public policies and legal science, this thesis seeks to understand the trajectory of the teaching profession in public schools. The study of policies, considering its legislative formulations and historical context, makes it possible to understand the institutional characteristics of the Brazilian State, and which factors make it difficult to comply with the constitutional commands aimed at the valorization of that activity. This regards especially those contained in sections $\mathrm{V}$ (career plans and remuneration) and VIII (salary national professional floor) of art. 206 of the Constitution. Currently, the National Education Plan of 2014 sets concrete goals in this sense, mainly in what comes to Goals 17 and 18 . However, they were deeply compromised in their accomplishment. The progress in this area involves an understanding of federative dynamics and legal, political and financial obstacles to the establishment of a national policy aimed at enhancing the teaching career. Evidence points that there is an insufficiency of the regulatory and inductive policies already practiced and an unrealism of proposals which promote an over centralization. Therefore, it is possible to conclude that there is a need to favor solutions that reinforce the system of collaboration between the entities of the federation, through an inductive and coordinative action of the Union, including collaborative arrangements and interfederative consortia. Only through agreed policies and by the effective implementation of a National Education System it is possible to overcome the horizontal and vertical inequalities presented in the Brazilian federation - including those related to the discrepancies in the career and remuneration of the public teachers.
\end{abstract}

Keywords: Teacher policy. Education. Teacher career. Educational policy. 


\section{LISTA DE SIGLAS}

ABE Associação Brasileira de Educação

ABESC Associação Brasileira de Escolas Superiores Católicas

ADC Ação Declaratória de Constitucionalidade

ADCT Ato das Disposições Constitucionais Transitórias

ADE Arranjos de Desenvolvimento da Educação

ADI Ação Direta de Inconstitucionalidade

AECB Associação de Educação Católica do Brasil

ANDE Associação Nacional de Educação

ANDES Sindicato Nacional dos Docentes das Instituições de Ensino Superior

ANDIFES Associação Nacional dos Dirigentes das Instituições Federais de Ensino

Superior

ANPAE Associação Nacional de Política e Administração da Educação

ANPED Associação Nacional de Pós-Graduação e Pesquisa em Educação

BID Banco Interamericano de Desenvolvimento

CAPES Coordenação de Aperfeiçoamento de Pessoal de Nível Superior

CAQ Custo-Aluno-Qualidade

CAQi Custo-Aluno-Qualidade Inicial

CCJC Comissão de Constituição e Justiça e de Cidadania

CE Comissão de Educação

CEAB Centro de Estudos Afro-Brasileiros

CEAC Centro de Estudos e Acompanhamento da Constituinte

CEB Câmara de Educação Básica

CEC Comissão de Educação e Cultura

CEDES Centro de Estudos, Educação e Sociedade

CEE/SP Conselho Estadual de Educação de São Paulo

CEETEPS Centro Estadual de Educação Tecnológica Paula Souza

CEFAM Centros de Formação e Aperfeiçoamento do Magistério

CENPEC Centro de Estudos e Pesquisas em Educação, Cultura e Ação Comunitária

CEPAL Comissão Econômica para a América Latina

CF/88 Constituição Federal de 1988

CFE Conselho Federal de Educação

CFT Comissão de Finanças e Tributação

CGT Confederação Geral dos Trabalhadores

CNE Conselho Nacional de Educação

CNEC Campanha Nacional de Escolas da Comunidade

CNM Confederação Nacional dos Municípios

CNTE Confederação Nacional dos Trabalhadores em Educação

CONAE Conferência Nacional de Educação

CONFAZ Conselho Nacional de Política Fazendária

CONSED Conselho Nacional de Secretários de Educação

CONTEE Confederação Nacional dos Trabalhadores em Estabelecimentos de Ensino

CPB Confederação dos Professores do Brasil

CRUB Conselho de Reitores das Universidades Brasileiras de Ensino Superior no

Estado de São Paulo

CTI Centro de Trabalho Indigenista

CUT Central Única dos Trabalhadores 


\begin{tabular}{|c|c|}
\hline DRU & Desvinculação de Receitas da União \\
\hline EC & Emenda à Constituição \\
\hline EM & Exposição de motivos \\
\hline ENAP & Escola Nacional de Administração Pública \\
\hline ENEM & Exame Nacional do Ensino Médio \\
\hline FASUBRA & Federação das Associações dos Servidores das Universidades Brasileiras \\
\hline FBAPEF & Federação Brasileira de Associações de Professores de Educação Física \\
\hline FINEDUCA & Associação Nacional de Pesquisa em Financiamento da Educação \\
\hline FITEE & Federação Interestadual dos Trabalhadores em Estabelecimentos de Ensino \\
\hline FNCEE & Fórum Nacional dos Conselhos Estaduais de Educação \\
\hline FNE & Fórum Nacional de Educação \\
\hline FUNDAP & Fundação do Desenvolvimento Administrativo \\
\hline FUNDEB & Fundo de Manutenção e Desenvolvimento da Educação Básica \\
\hline FUNDEF & $\begin{array}{l}\text { Fundo de Manutenção e Desenvolvimento do Ensino Fundamental e de } \\
\text { Valorização do Magistério }\end{array}$ \\
\hline FUVEST & Fundação Universitária para o Vestibular \\
\hline IBGE & Instituto Brasileiro de Estatística e Geografia \\
\hline ICMS & Imposto sobre Circulação de Mercadoria e Serviços \\
\hline IDEB & Índice de Desenvolvimento da Educação Básica \\
\hline INEP & Instituto Nacional de Estudos e Pesquisas Educacionais Anísio Teixeira \\
\hline IPEA & Instituto de Pesquisa Econômica Aplicada \\
\hline IPI & Imposto sobre produtos industrializados \\
\hline ISS & Imposto sobre serviços \\
\hline LDB & Lei de Diretrizes e Bases da Educação Nacional \\
\hline MDE & Manutenção e Desenvolvimento do Ensino \\
\hline MEC & Ministério da Educação \\
\hline MIEIB & Movimento Interfóruns de Educação Infantil do Brasil \\
\hline MP & Medida provisória \\
\hline MUNIC & Pesquisa de Informações Básicas Municipais \\
\hline $\mathrm{OCB}$ & Organização das Cooperativas Brasileiras \\
\hline OCDE & Organização para a Cooperação e o Desenvolvimento Econômico \\
\hline ONU & Organização das Nações Unidas \\
\hline PAR & Plano de Ações Articuladas \\
\hline PARFOR & Plano Nacional de Formação de Professores da Educação Básica \\
\hline PDE & Plano de Desenvolvimento de Educação \\
\hline PEC & Projeto de Emenda à Constituição \\
\hline PIB & Produto interno bruto \\
\hline PISA & $\begin{array}{l}\text { Programme for International Student Assessment (Programa Internacional de } \\
\text { Avaliação de Alunos) }\end{array}$ \\
\hline PL & Projeto de lei \\
\hline PLC & $\begin{array}{l}\text { Projeto de lei da Câmara dos Deputados (tal como identificado no sistema do } \\
\text { Senado Federal) }\end{array}$ \\
\hline PLP & Projeto de lei complementar \\
\hline PNAD & Pesquisa Nacional por Amostra de Domicílios \\
\hline PNE & Plano Nacional de Educação \\
\hline PORD & Pesquisa Observatório da Remuneração Docente \\
\hline PROIFES & $\begin{array}{l}\text { Federação de Sindicatos de Professores de Instituições Federais de Ensino } \\
\text { Superior }\end{array}$ \\
\hline PROUNI & Programa Universidade para Todos \\
\hline PSPN & Piso Salarial Profissional Nacional do Magistério \\
\hline
\end{tabular}




$\begin{array}{ll}\text { RAIS } & \text { Relação Anual de Informações Sociais } \\ \text { RE } & \text { Recurso Extraordinário } \\ \text { REsp } & \text { Recurso Especial } \\ \text { SAEB } & \text { Sistema Nacional de Avaliação da Educação Básica } \\ \text { SASE } & \text { Secretaria de Articulação com os Sistemas de Ensino } \\ \text { SBPC } & \text { Sociedade Brasileira para o Progresso da Ciência } \\ \text { SEAF } & \text { Sociedade de Estudos e Atividades Filosóficas } \\ \text { SETEC } & \text { Secretaria de Educação Profissional e Tecnológica } \\ \text { STF } & \text { Supremo Tribunal Federal } \\ \text { STJ } & \text { Superior Tribunal de Justiça } \\ \text { TCE } & \text { Territórios de Cooperação Educacional } \\ \text { TPE } & \text { Todos pela Educação } \\ \text { UBES } & \text { União Brasileira dos Estudantes Secundaristas } \\ \text { UDEMO } & \text { União dos Diretores de Escolas do Magistério Oficial de São Paulo } \\ \text { UFG } & \text { Universidade Federal de Goiás } \\ \text { UFMG } & \text { Universidade Federal de Minas Gerais } \\ \text { UFPR } & \text { Universidade Federal do Paraná } \\ \text { UNCME } & \text { União Nacional dos Conselhos Municipais de Educação } \\ \text { UNDIME } & \text { União Nacional dos Dirigentes Municipais de Educação } \\ \text { UNE } & \text { União Nacional dos Estudantes } \\ \text { UNESCO } & \text { Organização das Nações Unidas para a Educação, a Ciência e a Cultura } \\ \text { UNI } & \text { União das Nações Indígenas } \\ \text { UNICAMP } & \text { Universidade Estadual de Campinas } \\ \text { UNICEF } & \text { Fundo das Nações Unidas para a Infância } \\ \text { USP } & \text { Universidade de São Paulo } \\ \text { VAA } & \text { Valor Anual por Aluno }\end{array}$




\section{LISTA DE TABELAS}

Tabela 1 - Cumprimento da Lei do PSPN pelos Municípios

Tabela 2 - Progressão do reajuste do PSPN

Tabela 3- Escala de vencimentos Professor Educação Básica I - Estado de São

Paulo

Tabela 4 - Projeção sobre participação da União na MDE após a EC nº 95/2016

Tabela 5 - Resumo do Cálculo do CAQ_PNE nas escolas típicas para o sistema de 235 ensino regular 


\section{LISTA DE ILUSTRAÇÕES}

Gráfico 1- Ranking relativo ao prestígio da atividade docente

Figura 1- Quadro conceitual da atividade docente

Figura 2 - Mapa conceitual sobre a noção do desenvolvimento profissional

Quadro 1 - Ensino público e particular: remuneração média mensal dos professores do ensino médio de primeiro grau e número de salários médios (índice) por nível de instrução, segundo região e local de residência - 1982

Quadro 2-Comparativo dos projetos da LDB

Quadro 3 - Comparativo dos projetos sobre o PSPN

Quadro 4 - Principais modelos decisionais

Gráfico 2 - Evolução do IDEB

Gráfico 3 - Evolução do vencimento docente inicial nas redes estaduais (2006-2014)

Gráfico 4 - Evolução da Meta nº 18 do PNE (2014-2017)

Quadro 5 - Grade de análise: modelos de repartição de competências 


\section{SUMÁRIO}

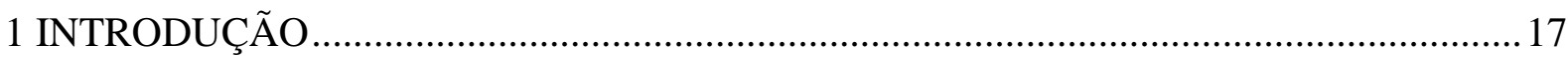

2 A POLÍTICA DE CARREIRA DOCENTE COMO OBJETO DE PESQUISA ....................21

2.1 CONCEITOS RELEVANTES PARA A PESQUISA: POLÍTICAS PÚBLICAS, ARRANJOS INSTITUCIONAIS, POLÍTICAS EDUCACIONAIS E POLÍTICAS DE

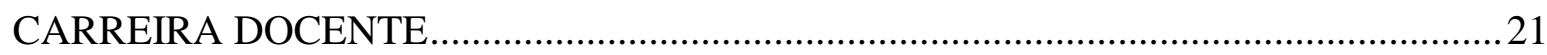

2.2 ENTENDENDO MELHOR AS POLÍTICAS DE CARREIRA DOCENTE ...................25

2.3 A SITUAÇÃO DA CARREIRA DOCENTE NO BRASIL COMO PROBLEMA DE

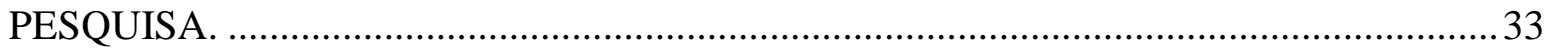

2.4 EMBASAMENTO TEÓRICO E METODOLÓGICO DA PESQUISA...........................38

3 POLÍTICAS EDUCACIONAIS E POLÍTICAS DE CARREIRA DOCENTE:

TRAJETÓRIA HISTÓRICA 43

3.1 O SISTEMA DE ENSINO E O REGIME DA DOCÊNCIA NO PERÍODO IMPERIAL

3.2 A PRIMEIRA REPÚBLICA: DESCENTRALIZAÇÃO E REFORMAS (1889 - 1920)

3.3 DÉCADA DE VINTE: ENTUSIASMO EDUCACIONAL E OTIMISMO

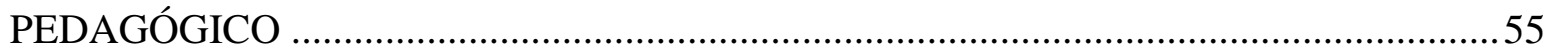

3.4 A REVOLUÇÃO DE 30 E O IMPULSO REFORMISTA ……………………..........59

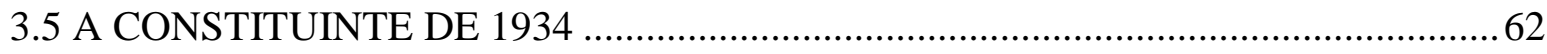

3.6 A REFORMA DAS CARREIRAS PÚBLICAS - 1936 ..............................................66

3.7 O ESTADO NOVO E A MODERNIZAÇÃO AUTORITÁRIA …………………….......68

3.8 O ENTREATO DEMOCRÁTICO E A PRIMEIRA LEI DE DIRETRIZES E BASES DA

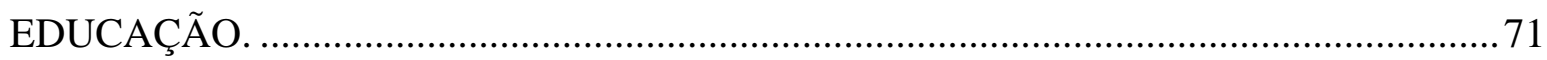

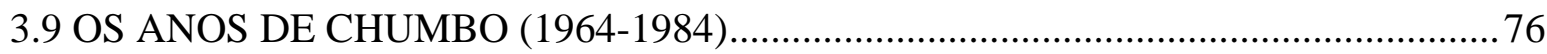

3.10 DESAFIOS DA REDEMOCRATIZAÇÃO: A CONSTITUINTE DE 1987-1988 ......81

3.11 TRAJETÓRIA HISTÓRICA DAS POLÍTICAS EDUCACIONAIS E DAS POLÍTICAS DOCENTES: CONCLUSÕES PRELIMINARES ..........................................91

4 A CARREIRA DOCENTE NA ORDEM CONSTITUCIONAL DE 1988 ............................99

4.1 O CONTEXTO DA NOVA ORDEM CONSTITUCIONAL ……………………….......99

4.2 REFORMAS CONSTITUCIONAIS E SEUS IMPACTOS NO REGIME JURÍDICO DO MAGISTÉRIO E NA DOCÊNCIA DA EDUCAÇÃO BÁSICA ……………………........101

4.3 AS LEIS NACIONAIS CONFORMADORAS DO REGIME JURÍDICO DA

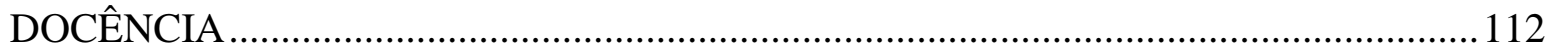

4.3.1 A Lei de Diretrizes e Bases da Educação - 1996 ............................................................112 
4.3.2 Os Fundos de financiamento da educação e seu impacto no custeio da atividade docente

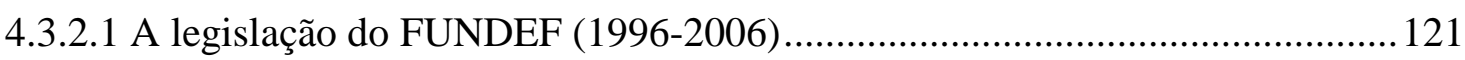

4.3.2.2 A legislação do FUNDEB (2007-2020) ..................................................... 131

4.3.3 A Lei do Piso Salarial Nacional dos Professores - Lei $n^{\circ}$ 11.738/2008 ....................... 136

4.3.3.1 O contencioso judicial sobre a Lei do Piso Salarial Profissional Nacional dos

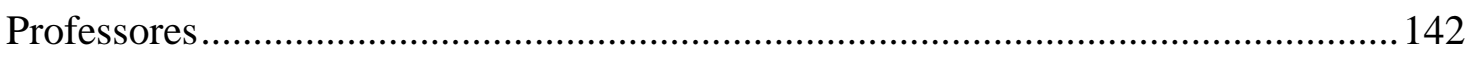

5 A CARREIRA DOCENTE NOS PLANOS EDUCACIONAIS ...................................... 155

5.1 O PLANEJAMENTO DAS POLÍTICAS PÚBLICAS ............................................ 155

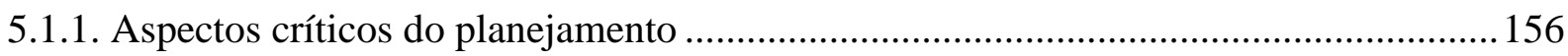

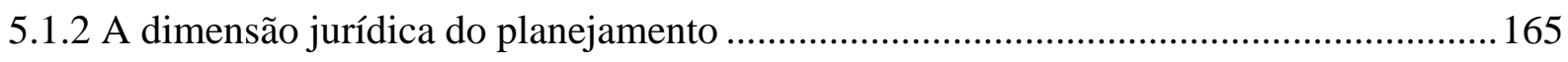

5.2 O PLANEJAMENTO NO ÂMBITO EDUCACIONAL ............................................ 174

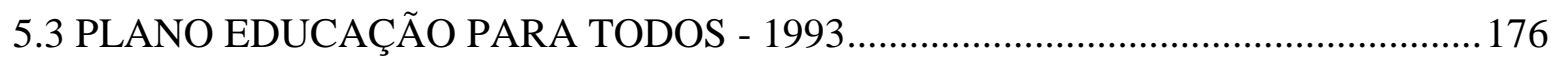

5.4 PLANO NACIONAL DE EDUCAÇÃO - PNE/2001 - LEI N 10.172/2001 .............. 180

5.5 PLANO DE DESENVOLVIMENTO DA EDUCAÇÃO - PDE................................ 185

5.6 PLANO NACIONAL DE EDUCAÇÃO - PNE/2014 - LEI N 13.005/2014.............. 194

6 A CONSTRUÇÃO DE UMA POLÍTICA NACIONAL DE CARREIRA DOCENTE:

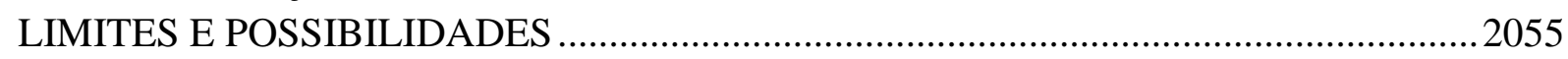

6.1 POLÍTICA NACIONAL DE CARREIRA DOCENTE: ENTRE TENTATIVAS E

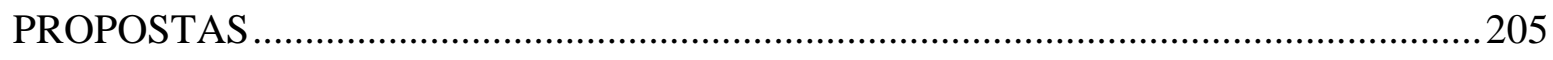

6.2 ANÁLISE DAS PROPOSTAS E INICIATIVAS VOLTADAS À VALORIZAÇÃO DA

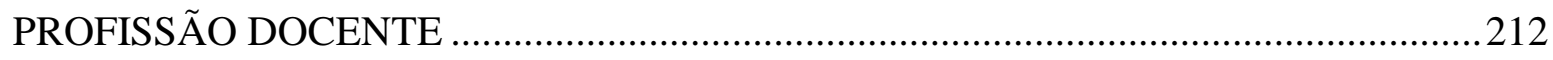

6.3 LIMITAÇÕES INSTITUCIONAIS PARA A CONSTITUIÇÃO DE UMA POLÍTICA

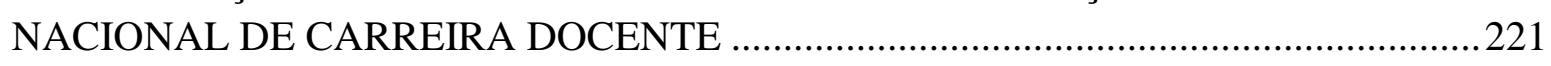

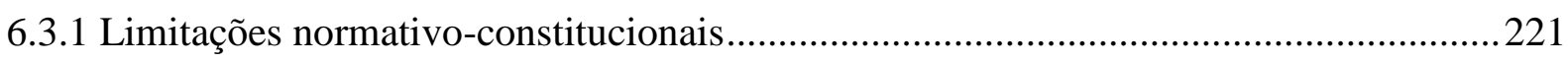

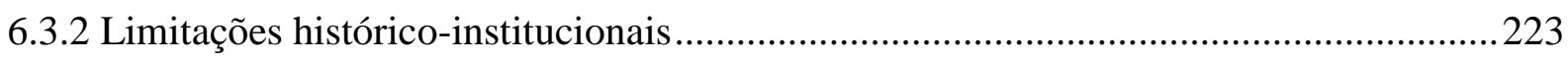

6.3.3 Limitações relativas ao financiamento das políticas educacionais...............................227

6.4 O ESTABELECIMENTO DE UM SISTEMA NACIONAL DE EDUCAÇÃO COMO ELEMENTO VIABILIZADOR DE UMA POLÍTICA NACIONAL DE CARREIRA

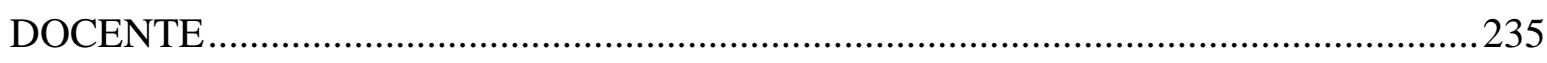

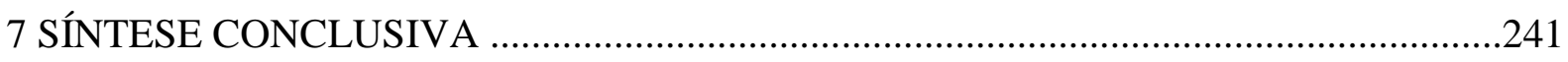

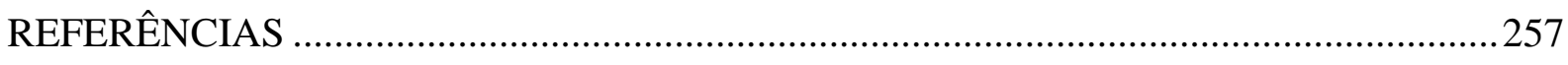





\section{INTRODUÇÃO}

Cento e noventa e um anos completos nos separam da pioneira lei nacional de educação - Lei de 15 de outubro de 1827 -, diploma que propunha a universalização do ensino e estabelecia regras básicas de arregimentação e remuneração dos professores.

Passados quase duzentos anos, é certo que o Estado Brasileiro ainda não conseguiu desempenhar a contento a tarefa a que se atribuiu desde sua gênese, não obstante a educação figure como direito fundamental, reconhecido nos arts. $6^{\circ}$ e 205 da Constituição Federal $(\mathrm{CF} / 88)$ vigente.

Dentre as possíveis causas da insuficiência do serviço de educação oficial, não será injusto alinhar a dificuldade de estabelecer políticas consistentes de valorização dos profissionais do magistério da educação básica, o que leva à repetida afirmação, já integrada no senso comum, do desvalor dessa profissão em nossa sociedade.

Prova dessa afirmação é a divulgação de recentíssimo estudo internacional, o Global Teacher Status Index 2018 (DOLTON et al., 2018), que propõe um ranking relacionado ao prestígio da atividade docente em 35 países. Às vezes, a imagem é mais eloquente do que as palavras, por essa razão, melhor do que descrever, é ilustrar:

Gráfico 1- Ranking relativo ao prestígio da atividade docente

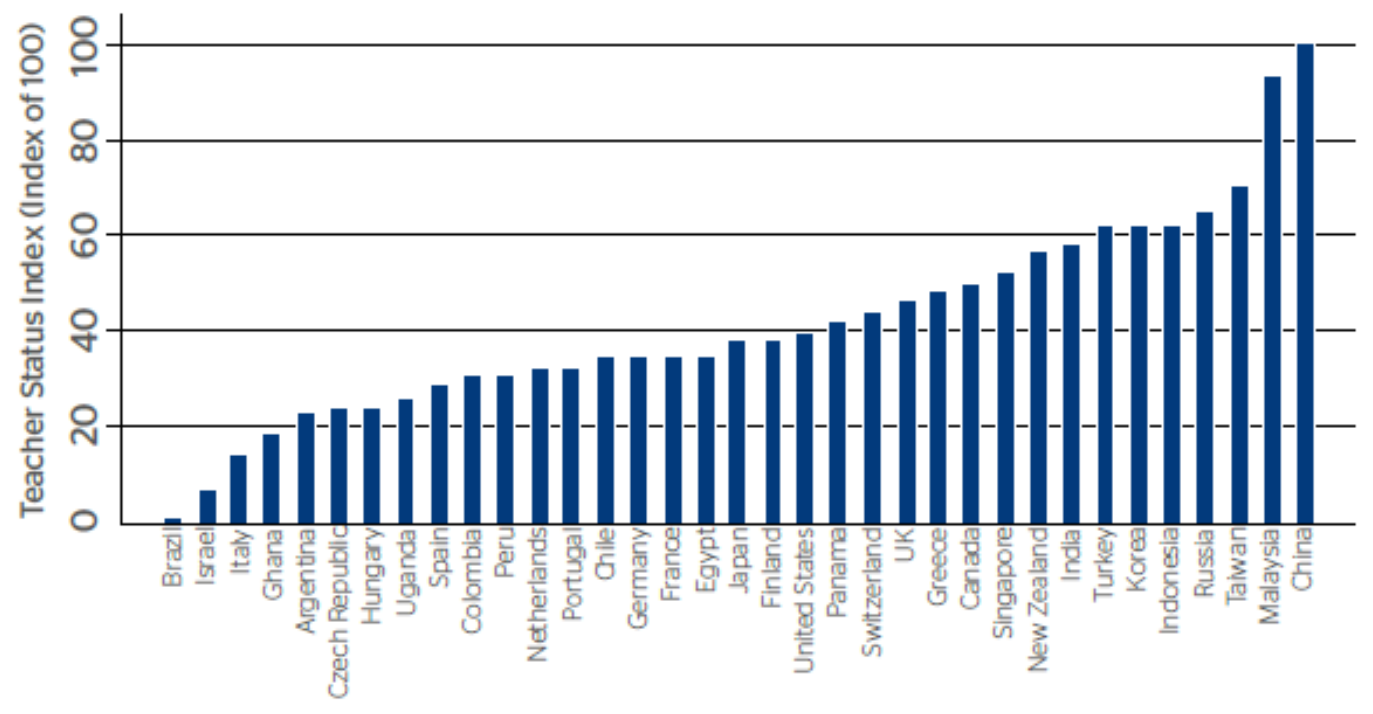

35 survey countries indexed on a relative scale 1-100

Fonte: DOLTON et al., 2018. 
Não é de hoje o quadro de desprestígio. A preocupação em revertê-lo levou à inclusão, no texto da Constituição vigente, de disposições dedicadas especialmente à valorização da carreira docente, determinando o estabelecimento de planos de carreira para o magistério em todas as unidades da federação (art. 206, inciso V) e a fixação de um piso salarial nacional para os professores e demais profissionais da educação (art. 206, inciso VIII). Ou seja, o Constituinte impôs como subsistema da política educacional do país, uma política de carreira docente a ser implementada a partir da atuação coordenadora e supletiva da União e envolvendo todos os entes federados, visto que todos atuam na educação básica.

Esses dois elementos - o plano de carreira e o piso salarial nacional profissional formam um complexo arranjo jurídico que compõe um dos eixos essenciais da política educacional e no qual confluem muitos dos conflitos políticos e jurídicos atinentes à educação em nosso país. Não por outra razão, eles foram congregados na Meta $\mathrm{n}^{\circ} 18$ do Plano Nacional de Educação (PNE) 2014-2024 - Lei nº 13.005, de 25 de junho de 2014:

Meta 18: assegurar, no prazo de 2 (dois) anos, a existência de planos de Carreira para os (as) profissionais da educação básica e superior pública de todos os sistemas de ensino e, para o plano de Carreira dos (as) profissionais da educação básica pública, tomar como referência o piso salarial nacional profissional, definido em lei federal, nos termos do inciso VIII do art. 206 da Constituição Federal.

Atreladas a essa Meta, o PNE indica, de forma não-exaustiva, ${ }^{1}$ estratégias destinadas ao seu cumprimento. Investigá-las, analisando as dificuldades jurídico-institucionais de sua implementação e eventuais percursos alternativos será um dos desafios de nossa tese.

Nesta pesquisa, importa-nos mapear os elementos jurídico-institucionais que conformam e condicionam o comportamento dos atores envolvidos - atores governamentais, e não-governamentais, policy makers e policy takers - e que tipos de conflitos, especialmente os de natureza jurídica, têm permeado a implementação dos elementos da política de carreira docente. O intuito é propiciar elementos de análise e de atuação estratégica que possibilitem

\footnotetext{
${ }^{1}$ Art. $7^{\circ}$ A União, os Estados, o Distrito Federal e os Municípios atuarão em regime de colaboração, visando ao alcance das metas e à implementação das estratégias objeto deste Plano.

$\S 1^{\circ}$ Caberá aos gestores federais, estaduais, municipais e do Distrito Federal a adoção das medidas governamentais necessárias ao alcance das metas previstas neste PNE.

$\S 2^{\circ}$ As estratégias definidas no Anexo desta Lei não elidem a adoção de medidas adicionais em âmbito local ou de instrumentos jurídicos que formalizem a cooperação entre os entes federados, podendo ser complementadas por mecanismos nacionais e locais de coordenação e colaboração recíproca.
} 
a construção e efetivação de políticas juridicamente consistentes e capazes de cumprir o desiderato constitucional.

Para tanto, nosso estudo será dividido em cinco capítulos. No primeiro capítulo, nos dedicaremos a esclarecer os conceitos básicos adotados na pesquisa e os elementos metodológicos empregados, ressaltando seu caráter interdisciplinar e sua inserção na tradição teórica do neoinstitucionalismo histórico.

No segundo capítulo, procederemos à análise da trajetória da política de carreira docente, buscando conectá-la às diversas fases da política educacional do país, bem como ao respectivo quadro constitucional e ao contexto histórico correspondentes. Buscaremos assim compreender o longo percurso que antecedeu a promulgação da Constituição de 1988, mapeando as continuidades e descontinuidades que permitiram a emergência de um projeto constitucional ousado, em seu intento de universalizar o acesso e de elevar a qualidade da educação nacional, mas ainda inacabado no tocante à efetivação de seus propósitos.

No terceiro capítulo, faremos um balanço da trajetória da Constituição de 1988, especialmente das reformas que impactaram seu projeto educacional original e as transformações do regime jurídico que ela traçou inicialmente para o magistério público. Interessa-nos também compreender as inovações trazidas pelos fundos nacionais - Fundo de Manutenção e Desenvolvimento do Ensino Fundamental e de Valorização do Magistério (FUNDEF) e Fundo de Manutenção e Desenvolvimento da Educação Básica (FUNDEB) e pelas leis regulamentadoras do texto constitucional. A saber, a Lei de Diretrizes e Bases da Educação (Lei no 6.364/96) e a Lei do Piso Nacional Profissional do Magistério (Lei $\mathrm{n}^{\circ}$ 11.738/2008). Teremos, então, a possibilidade de observar como os conflitos políticos que permearam os trabalhos da Constituinte persistiram, seja nos embates legislativos, seja na forma de conflitos judiciais referentes à implementação dos mecanismos de valorização da carreira docente previstos no Texto Constitucional.

O quarto capítulo será dedicado a compreender como se dá a articulação das medidas voltadas à valorização docente por meio dos planos educacionais. A atividade planejadora tem, por sua própria feição, uma natureza marcadamente racional, instrumental e prospectiva e é o instrumento, por excelência, da realização dos propósitos do Estado Social, ainda que na forma por vezes segmentada das políticas públicas. A compreensão da atividade planejadora, seus desafios e riscos, especialmente em sua dimensão jurídica, favorece o aprendizado para um melhor desenho e uma mais eficiente implementação das políticas 
públicas. No âmbito educacional, a função planejadora alcança uma importância fulcral na fixação de diretrizes de longo prazo e na coordenação de todos os sujeitos envolvidos no processo educativo, bem como na combinação dos esforços de todos os entes da federação, em prol da melhoria da educação básica. Os planos educacionais - e aqui se destaca, evidentemente, o Plano Nacional de Educação - desempenham um papel axial, na articulação das políticas educacionais, por meio de diagnósticos, estratégias e metas capazes de mobilizar a atenção e a energia de todos os envolvidos na tarefa educacional, inclusive no que concerne à valorização da docência.

No capítulo final, a partir do aprendizado haurido nas seções precedentes, analisaremos propostas voltadas ao reconhecimento do magistério, especialmente no tocante à reestruturação da carreira docente em âmbito nacional, sendo que já há algumas formulações em debate na arena política. Interessa-nos aqui compreender porque as medidas já adotadas ao longo do trintênio constitucional, embora tenham produzido alguma equalização na remuneração e na condição de trabalho dos docentes em nossa federação ainda fortemente marcada por desigualdades verticais e horizontais -, não foram capazes de reverter o quadro de precariedade que vem caracterizando a profissão em nosso país. Avulta aqui a importância de consolidação de um regime de colaboração que propicie a melhor distribuição dos recursos destinados à prestação educacional, sendo que arranjos colaborativos podem ser um caminho promissor para contornar as dificuldades em dotar o país de práticas mais coerentes e efetivas na valorização da atividade docente.

Às vésperas de um novo ciclo governamental, assoma-nos o temor de que décadas de trabalho árduo e de luta incansável de muitos brasileiros que, independentemente de sua afeição ou filiação política, vêm debatendo e aperfeiçoando a prestação educacional, seja descartada em prol de um revisionismo anacrônico. Se há uma lição que a história nos ensina é que, assim como a natura non facit saltus, o aprimoramento da cultura humana depende da compreensão, destituída de preconceitos, do acervo de sucessos e equívocos que nos precederam na árdua tarefa civilizatória.

Nossa esperança é que um pouco do nosso suor, despendido neste trabalho, com seus muitos erros e alguns acertos, seja uma partícula, ainda que pequena, na argamassa da construção ainda inacabada de uma nação capaz de educar seus filhos para uma vida iluminada sob o sol da liberdade. 


\section{SÍNTESE CONCLUSIVA}

1. As políticas de carreira docente formam um todo complexo de medidas destinadas a atrair, selecionar, formar e conservar os profissionais dedicados à atividade educacional. Para sua melhor compreensão, o estudo da trajetória de tais políticas deve estar conectado à investigação das políticas educacionais e das políticas de gestão de pessoal adotadas em dado contexto histórico, bem como aos arranjos jurídico-institucionais construídos para lhes dar sustentação.

2. O regime jurídico da carreira docente é um elemento central de tais políticas, sendo que a literatura internacional aponta dois modelos básicos: os sistemas baseados em carreira (career-based systems), associado aos esquemas burocráticos tradicionais e historicamente atrelado à afirmação do Estado-providência; e os sistemas baseados em postos de trabalho (position-based systems), que privilegiam a escolha dos profissionais para determinada função em virtude de habilidades específicas, em que não há progressões automáticas e que recompensas remuneratórias são orientadas pela busca de resultados. Tal esquematização não exclui a hibridização de modelos, com a coexistência de sistemas de carreira com mecanismos de incentivos atrelados a resultados, como se observa, por exemplo, com a legislação estadual paulista.

3. Embora o resultado da atividade educacional seja dependente de múltiplos fatores, a pesquisa empírica desenvolvida nos últimos cinquenta anos é conclusiva no tocante ao impacto da qualidade dos professores no desenvolvimento dos alunos. Portanto, adotar políticas de carreira adequadas, que tornem atrativa e valorizada a profissão docente, é um passo imprescindível para propiciar o pleno florescimento dos educandos, com evidentes repercussões no desenvolvimento econômico-social do país e em sua capacidade para enfrentar os desafios da contemporaneidade.

4. Pode-se observar tal preocupação na Constituição Federal de 1988, ao determinar o estabelecimento de planos de carreira para o magistério em todas as unidades da federação (art. 206, inciso V) e a fixação de um piso salarial nacional para os professores e demais profissionais da educação (art. 206, inciso VIII). Ou seja, o Constituinte impôs como subsistema da política educacional do país, uma política de carreira docente a ser 
implementada a partir da atuação coordenadora e supletiva da União e envolvendo todos os entes federados.

5. É digno de nota que a primeira legislação nacional sobre a profissão docente, datada de 1827, já estabelecia um esboço de carreira docente, acessível por meio de concurso público e dotada de piso remuneratório nacional. À época já se observava que o exercício do magistério, embora dotasse o seu titular de um status de fidalguia, não era acompanhado de remuneração condigna, embora houvesse uma vinculação tributária para custear o ensino o chamado subsídio literário. Ao final do período imperial, percebe-se que nem a lei pioneira nem as reformas implantadas no período foram capazes de dotar o país de um sistema público abrangente e tampouco elevaram a dignidade dos mestres, sujeitos a vencimentos parcos e constantemente atrasados.

6. A República traz em seu seio os ideais modernizadores do positivismo, vislumbráveis no projeto reformista de BENJAMIN CONSTANT, que propõe um esquema tipicamente burocrático - no sentido weberiano - de carreira docente. Todavia, o propósito modernizador encontra severos entraves na estrutura arcaica e oligárquica herdada do período imperial, sendo o poder central incapaz de promover alterações de monta, dado o federalismo extremado da assim chamada "República dos Governadores". Assim, o desenvolvimento das instituições educacionais - e, por consequência, de carreiras docentes profissionais - depende fortemente do interesse das oligarquias locais, o que propicia o aprofundamento das desigualdades regionais. Ao passo que em alguns Estados se estabelecem reformas promissoras - a paulista, iniciada por CAETANO DE CAMPOS é o paradigma - a lógica patrimonialista continua a predominar na gestão escolar.

7. Na década de vinte, porém, manifesta-se uma forte inquietação da elite intelectual do país, o que propicia a realização de "inquéritos" educacionais, a constituição de uma entidade de caráter nacional dedicada ao tema - a Associação Brasileira de Educação (ABE) - e a realização de Conferências Nacionais de Educação. Esse momento, caracterizado por JORGE NAGLE (2009) pelo entusiasmo pela escolarização e otimismo pedagógico, favoreceria a eclosão posterior do movimento escolanovista, cujo principal intento era propagar na agenda política nacional o ideal de uma escola pública, gratuita, obrigatória e laica.

8. A vaga modernizante deflagrada pela revolução de 1930 também se fez sentir no âmbito educacional, o que se reflete na criação de um Ministério dedicado ao tema - 
Ministério da Educação e Saúde - e na instituição de um Conselho Nacional de Educação. Por ocasião da quarta Conferência Brasileira de Educação, em 1932, vem à luz o Manifesto dos pioneiros da educação, marco do movimento escolanovista e que se tornaria peça doutrinária incontornável na discussão das políticas educacionais futuras. A tendência modernizadora e racionalizadora também se fez sentir em reformas estaduais, tal como se observa no extenso Código de Educação elaborado por um escolanovista, FERNANDO DE AZEVEDO, em 1933, em que se destaca a estruturação de uma carreira do magistério baseada em padrões meritocráticos e com notável preocupação com a formação docente.

9. A Constituição de 1934 reflete o debate entre correntes de variado matiz - liberais, tradicionalistas, católicos, autoritários etc. - incorporando parcialmente a agenda modernizadora do escolanovismo. Destaca-se a reestruturação do modelo federativo no tocante ao ensino, ampliando-se as competências da União, que passa a ter um papel coordenador, por meio de plano nacional de educação, a ser elaborado pelo Conselho Nacional de Educação e aprovado pelo Legislativo. Sobre os docentes, evidencia-se a preocupação com sua remuneração condigna, a garantia da liberdade de cátedra, a admissão por concurso público e a garantia de vitaliciedade e inamovibilidade aos concursados dos institutos oficiais.

10. No mesmo período observa-se uma preocupação marcante com a modernização do aparato estatal federal, o que se revela pela promulgação da Lei do Reajustamento (1936), que visa implantar um quadro burocrático estruturado em carreiras, cada qual com escala vencimental própria, acessíveis os cargos por concurso público e com mecanismos de evolução funcional baseados no mérito e na antiguidade. Porém, a nova lei não venceu de forma definitiva as práticas clientelistas, mantida a livre nomeação nos cargos em comissão e acomodados os interesses por meio das figuras dos interinos e extranumerários. Alguns anos depois, o Estado de São Paulo produziu o primeiro Estatuto dos Funcionários Públicos (1941) e um esboço de Estatuto do Magistério, onde se prevê um estágio probatório de cento e oitenta dias após o concurso de ingresso e que condiciona diversas vantagens funcionais à progressão dos alunos. Ali prevê-se, também, a possibilidade de transferência de professores municipais para escolas estaduais - medida compatível com o enfraquecimento federativo então vigente, pois já se estava no Estado Novo.

11. O advento do Estado Novo favorece a vertente autoritária do escolanovismo, cujo expoente era FRANCISCO CAMPOS. A Carta de 1937 reflete esse viés, em que se destaca o elitismo educacional e uma inflexão em favor do ensino privado, este, porém, sempre 
submetido à rédea curta da burocracia ministerial. $\mathrm{O}$ forte centralismo que caracteriza o período coexistiu com mecanismos de pactuação, destacando-se o Convênio Nacional do Ensino Primário, em que os entes subnacionais se comprometeriam a aumentar a aplicação de recursos tributários, para o fim de receber verbas federais. Leis Orgânicas geradas durante o Estado Novo buscaram produzir uma padronização nacional do ensino, dispondo também sobre normas gerais da carreira docente, sendo que, nesse tocante, não se percebeu efeito uniformizador relevante nos entes subnacionais, de molde a substituir a práticas patrimonialistas tradicionais.

12. A Constituição de 1946 retoma, de forma mais sintética e parcimoniosa, o programa da Carta de 1934. Em relação ao regime docente, impunha-se concurso apenas para os cargos no ensino secundário e superior, garantindo-se a tais docentes a vitaliciedade e liberdade de cátedra. Após a promulgação da nova Constituição, seguiu-se longo debate sobre a Lei de Diretrizes e Bases da Educação, com embate entre uma aliança de forças conservadoras e uma frente de defesa da escola pública, encabeçada pelos escolanovistas de 1932. O texto resultante, promulgado em 1961, preocupa-se especialmente com a formação dos docentes e especialistas em educação, sendo silente em relação aos direitos profissionais, apenas preconizando a "garantia de remuneração condigna aos professores".

13. O período democrático iniciado em 1946 caracteriza-se também pelo esforço em pesquisar e debater a qualidade da educação, esforço esse capitaneado por ANÍSIO TEIXEIRA, à testa do INEP. Dentre as pesquisas realizadas, o estudo de LUIZ PEREIRA (1963) sobre a condição do professorado da Capital paulistana, ali verificando a transição para o modelo burocrático de gestão escolar, bem como a progressiva proletarização da profissão.

14. Essa proletarização se consolida durante o período autoritário, em que se promove a expansão da rede escolar pública ao mesmo passo que se reduz o investimento em educação, abolida a vinculação de recursos tributários pela Carta de 1967, somente retomada plenamente em 1985, por força da Emenda "Calmon”. O caráter autoritário-centralizador do regime, aliado à dependência financeira de transferências federais, reduziu a autonomia dos entes subnacionais, sendo que a dominação tecnoburocrática coexistia com as barganhas clientelísticas de sempre. Além do arrocho salarial, a liberdade de cátedra restou severamente restringida pelas medidas de exceção do período, dentre as quais figurava o processo demissional sumário dos docentes que veiculassem conteúdo considerado subversivo. 
15. A partir da aprovação da nova Lei de Diretrizes e Bases, em 1971, o regime buscou ampliar a oferta de professores, reestruturando o processo de formação do magistério e impondo aos entes subnacionais o estabelecimento de estatutos específicos, com conteúdo mínimo prefixado em Decreto federal. Embora tenha gerado alguma movimentação dos Estados, não se pode concluir que a medida tenha sido efetiva em âmbito municipal, em um momento em que se iniciava a tendência de municipalização do ensino, em algumas regiões do país.

16. Enormes desafios se apresentavam por ocasião da redemocratização do país, no campo educacional. No tocante à profissão docente, o nível de escolarização dos docentes era precário, especialmente nas zonas rurais e nas regiões mais pobres do país. A proletarização da profissão se confirmava, com salário médio inferior a duzentos dólares e enormes discrepâncias remuneratórias, a depender da formação do docente, região de domicílio ou localização (urbana ou rural) do estabelecimento escolar.

17. O processo constituinte ocorrido em 1987/1988 produziu enorme mobilização popular e intensa participação de grupos organizados nos trabalhos da Assembleia Nacional Constituinte. Atores dos vários campos interessados na questão educacional se mobilizaram em frentes e coalizões, com vistas a influenciar o resultado final do processo. No âmbito da Subcomissão dedicada ao tema, propôs-se a criação de uma carreira nacional do magistério e foram acolhidas boa parte das reivindicações da classe docente, destacando-se a influência da Carta de Goiânia, produzida na IV Conferência Brasileira de Educação (1986). Ao final do processo, todavia, fez-se sentir a influência do bloco político conhecido como "Centrão", o que levou à necessidade de adoção de um texto compromissário, porém com diversos avanços relevantes. Dentre eles, consagrou-se a "valorização dos profissionais do ensino, garantido, na forma da lei, plano de carreira para o magistério público, com piso salarial profissional e ingresso exclusivamente por concurso público de provas e títulos, assegurado regime jurídico único para todas as instituições mantidas pela União” (art. 206, IV).

18. A ordem constitucional instalada em 1988 nasce com perfil claramente inspirado nas democracias promotoras de bem-estar social da Europa do pós-guerra, modelo que já se encontrava em crise de sustentabilidade econômico-financeira. A resposta à crise vem na forma de receituário de agências internacionais, baseada na redução da máquina estatal, privatização e desregulamentação. No âmbito educacional, disseminam-se programas reformistas, que propõem a descentralização e a adoção de técnicas de gestão baseadas em resultado. 
19. Ocorrerá, nesse contexto, um duplo "ajustamento" da nova ordem constitucional: de um lado, há sucessivas reformas constitucionais visando ao aggiornamento do Texto Constitucional; de outro, haverá expedientes que, por meio de interpretação ou mera protelação legislativa, manterão adormecidos dispositivos programáticos atinentes aos direitos sociais.

20. O esforço reformista, embora iniciado no período Collor, ganhará impulso no Governo Fernando Henrique Cardoso, a partir da elaboração do Plano Diretor de Reforma do Aparelho do Estado, inspirado pela escola da New Public Management, aqui alcunhada de Gerencialismo ou Administração Gerencial. Suas propostas se consolidam especialmente na Emenda $n^{\circ}$ 19/98, que promoveu a chamada Reforma Administrativa. Suas disposições buscam consolidar certos traços do modelo burocrático-racional, agregando alguns aspectos do modelo gerencial, com ênfase na eficiência e na produtividade. Muitas de suas inovações, entretanto, não se efetivaram, o que se pode atribuir não apenas à resistência corporativa da burocracia, mas também à sobrevivência local de formas tradicionais de dominação, impedindo a aclimatação dos ideais meritocráticos do modelo gerencial.

21. No tocante ao serviço educacional, alguns efeitos da Reforma Gerencial se fizeram sentir, especialmente em três aspectos: o incremento das atividades de formação $e$ aperfeiçoamento dos agentes educacionais, com a ampliação de órgãos e programas dedicados à tarefa; a disseminação de uma cultura de avaliação, por meio dos diversos exames voltados ao acompanhamento do aprendizado e pela criação de índices específicos como o Índice de Desenvolvimento da Educação Básica - IDEB (2007); e a adoção de políticas de bonificação por resultados, cujas premissas básicas - a possibilidade de mensuração do "efeito escola" e a capacidade de induzir comportamentos dos agentes educacionais - estão sujeitas a forte questionamento por estudos recentes, que apontam efeitos indesejados, seja no tocante à motivação dos sujeitos envolvidos, seja no aprofundamento de desigualdades educacionais. No Brasil, a adoção de tais mecanismos de bonificação disseminou-se e persiste, pois se revelou um expediente vantajoso para cumprir a obrigação constitucional de dispêndio mínimo com o magistério, ao não impactar na folha de inativos e pensionistas e não gerar crescimento vegetativo da folha dos ativos.

22. Ao longo dos trinta anos de vigência da Constituição, fez-se necessário produzir complexa legislação regulamentadora do programa educacional nela formulado. A discussão da Lei de Diretrizes e Bases de Educação iniciou-se ainda em 1988, tendo sido aprovado em 1993 na Câmara dos Deputados um projeto acordado entre o Governo e os diversos setores 
interessados, resultante de uma "conciliação aberta", nas palavras do então deputado FLORESTAN FERNANDES. Por ocasião do governo FHC, o projeto, na forma do Substitutivo CID SABOYA, já se encontrava em condições de ir a plenário no Senado; todavia, a nova gestão adotou outro projeto, de autoria do Senador DARCY RIBEIRO, do qual resultou o texto promulgado da nova LDB. Em comparação com as versões produzidas ao longo da tramitação legislativa, percebemos que a LDB não conferiu ao Conselho Nacional de Educação o protagonismo cogitado nas proposituras descartadas; embora tenha detalhado o papel de cada ente da Federação na prestação educacional, não produziu um sistema nacional e tampouco previu mecanismos de coordenação interfederativa; no tocante à docência, a lei preocupou-se mais com aspectos relacionados à formação do que com a disciplina da carreira docente e seu regime laboral, em contraste com versões anteriores que buscavam criar uma carreira de âmbito nacional (PROJETO OCTAVIO ELísIO) ou regular detalhadamente os aspectos próprios da carreira do magistério (Substitutivos JORGE HAGE e CID SABOYA).

23. O efeito mais relevante da LDB diz respeito à aceleração do processo de descentralização do ensino, tornando os Municípios os principais provedores do serviço educacional público. Para que tal processo ocorresse, houve a necessidade de reajustar e equalizar o esquema de financiamento da educação, de modo a superar a incapacidade ou desinteresse dos Municípios em assumir ou ampliar sua atuação no ensino fundamental. A solução encontrada pelo gestão FHC foi engenhosa: por meio de uma PEC, estabeleceu-se o FUNDEF, um sistema de subvinculação de receitas tributárias em fundos contábeis estaduais, equalizando a disponibilidade de recursos, com base na distribuição de um valor mínimo por cada aluno matriculado nas redes do ensino fundamental. Malgrado o mérito de enfrentar a questão do descompasso entre receitas e encargos no arranjo federativo da Constituição de 1988, a inovação suscitou questionamentos vários, destacando-se: no âmbito jurídico, a dúvida quanto à constitucionalidade da solução; no âmbito operacional, a crítica à recusa da União em adimplir suas responsabilidades financeiras no ajuste. Os propalados efeitos benéficos do arranjo no tocante à valorização remuneratória e no estímulo à criação de planos de carreira em âmbito municipal são controversos, à luz da literatura analisada. Ao que tudo indica, o principal efeito do FUNDEF foi a equalização de recursos, favorecendo os Municípios de menor capacidade arrecadatória, onde as práticas remuneratórias estavam, muitas vezes, fora da legalidade.

24. Como substituição ao FUNDEF, ao fim de seu prazo decenal de vigência, o Governo LULA encaminhou propositura que, após amplo processo de negociação no 
Congresso Nacional, resultou na EC n ${ }^{\circ}$ 53/2007, criando o FUNDEB. Além de ampliar a abrangência de seu escopo - pois passou a financiar a educação básica em todas as etapas e modalidades - o novo arranjo propiciou significativo aumento do aporte financeiro da União, favorecendo a ideia de federalismo cooperativo que era subjacente ao mecanismo. Embora a inovação incremental propiciada pelo FUNDEB tenha propiciado uma relevante elevação no patamar de investimentos em educação - o que impactou na elevação da média remuneratória dos docentes ao longo do período - a literatura sobre financiamento educacional aponta sua insuficiência para garantir a "igualdade de condições para o acesso e permanência na escola" e o "padrão de qualidade" exigidos nos incisos I e VII do art. 206 da Constituição Federal. Um próximo passo nessa direção seria a implantação do Custo Aluno Qualidade - CAQ, mecanismo básico para medir a demanda financeira dos serviços educacionais, previsto como estratégia voltada ao cumprimento da Meta 20 (relativa à ampliação do investimento público em educação em relação ao PIB), no Plano Nacional de Educação 2014/2024. Todavia, a implantação do mecanismo vem sendo continuamente postergada pelo Governo Federal, a pretexto de afetar a observância de metas fiscais. A constrição fiscal ocasionada pelo Novo Regime Fiscal (EC nº 95/2016) e a expiração do FUNDEB em 2020 são indicadores de que o arcabouço de financiamento da educação, gestado ao longo das Gestões FHC e LuLA, está sob grave risco de desmantelamento, com evidente impacto na política de valorização docente, elemento nuclear da política de fundos educacionais.

25. O estabelecimento de um piso nacional para os professores era promessa que remontava ao Governo Itamar Franco e que vinha sendo procrastinada por mais de uma década. Somente em 2008, após a criação do FUNDEB, viabilizou-se politicamente a Lei do PSPN - Piso Salarial Profissional Nacional do Magistério. Sua promulgação, todavia, deflagrou um contencioso judicial que ainda não se encerrou. Em ADI ajuizada por Governadores de diversos Estados, o STF concedeu medida cautelar que suspendeu os efeitos da Lei do Piso, suspensão que perdurou até abril de 2011, em que houve julgamento de mérito, concluindo pela constitucionalidade do diploma. Até hoje, todavia, constata-se que grande parcela dos entes subnacionais não cumpre a legislação referente ao PSPN, situação de desconformidade tende a se agravar, em vista da crise fiscal em curso e pela limitação dos recursos disponíveis pelo Novo Regime Fiscal instituído na EC no 95/2016. Por essa razão, entidades representativas de Estados e Municípios vêm propondo a revisão da metodologia de atualização do PSPN, pois a atualmente vigente tem propiciado aumentos 
reais, independentemente da capacidade financeira dos entes federados $(42,39 \%$ no acumulado de 2010-2017). Outra tese relevante em discussão nos Tribunais Superiores diz respeito ao achatamento das escalas remuneratórias, que não são reajustadas na mesma proporção do PSPN. A tese - e aqui temos como exemplo paradigmático uma ação coletiva proposta pelo sindicato de professores do Estado de São Paulo - aponta que, à medida que o PSPN é reajustado, profissionais de diferentes níveis passam a perceber o mesmo vencimento-base, o que parece incompatível com a própria concepção de progressão na carreira. Ainda que a tese jurídica venha a ser superada - visto que implica em severo comprometimento da autonomia federativa - não se pode ignorar a ocorrência de um "conflito de efeitos", a ser enfrentado no desenho de futuras políticas. O aprendizado que se extrai desse contencioso é a necessidade de se conceber novas formas de articulação entre União e entidades subnacionais, harmonizando o exercício de suas competências constitucionais.

26. O planejamento é a ferramenta, por excelência, do Estado Social, em que o govern by law é substituído pelo govern by policies, promovendo uma coordenação distinta daquela que é estabelecida pelo jogo das forças do mercado. A atividade planejadora tem uma feição racional, instrumental e prospectiva, voltada para a realização de um determinado estado de coisas, em dado momento futuro. Não obstante sua inegável importância, há aspectos críticos que merecem ser ressaltados, a saber: a) o predomínio de uma visão técnico-burocrática, o que pode enfraquecer o controle democrático e minar a legitimidade das políticas públicas; b) a ênfase excessiva na fase de elaboração do plano, com predomínio de fluxos decisórios descendentes (top down), desprezando-se a importância dos sujeitos envolvidos na implementação; c) o emprego de modelos de racionalidade inadequados, não considerando as múltiplas variáveis envolvidas - números de atores e coalizões, recursos disponíveis, timing decisório, condições cognitivas, atenção pública etc. - e suas interações, adotando soluções "tecnicamente corretas" sem considerar os aspectos estratégicos da tomada de decisão.

27. O planejamento, como processo e o próprio plano, como produto final, possuem uma dimensão jurídica que nem sempre é objeto de devida atenção. Na visão jurídica do planejamento, merecem destaque as noções: de processualidade - em que a distensão da atividade no tempo e a dialética pluripessoal propiciam uma partilha qualitativa do poder (JUSTEN, 2016, p. 341) e favorecem a qualidade decisória; de participação - que é princípio transversal da Constituição (PEREZ, 2009, p. 215) e pressupõe a abertura dialógica dos 
processos decisórios, favorecendo a eficiência e legitimidade de seu resultado; de coordenação, que se revela especialmente por meio do plano, que tem o condão de conferir à atividade planejadora um caráter de produção normativa que potencializa seus efeitos enquanto instrumento de coordenação. O plano permite a atribuição de um caráter institucional à política pública, em que regras constitutivas criam uma estrutura significativa, capaz de criar um impulso para ação que seja independente da inclinação dos indivíduos (SEARLE 1996; 2005). O plano é formulado em torno de normas-objetivo (GRAU, 1990, p. 283), estruturadas em esquema "fim-meio", normas que, embora desprovidas de sanção, criam deveres jurídicos para os agentes incumbidos de sua implementação. Sua veiculação por meio de lei em sentido formal propicia maior legitimidade, segurança e exigibilidade, o que é especialmente importante quando seus efeitos alcançarem outros entes políticos. É justamente no âmbito interfederativo que os planos ganham uma peculiar função coordenadora, conjugando medidas impositivas, indutivas e indicativas, em um arranjo em que a mútua colaboração e a influência recíproca dos comportamentos são ingredientes obrigatórios.

28. O planejamento é inerente à dimensão temporal da atividade educativa, guiada necessariamente por ciclos temporais, revelando-se como atividade transversal, que envolve tanto as práticas pedagógicas quanto as atividades de gestão educacional. Embora a previsão de um plano nacional de educação remontasse à Constituição de 1934, somente em 2001, último ano da gestão FHC houve a promulgação do primeiro PNE decenal, em atendimento ao que dispunha o art. 214 da CF/88. O trâmite legislativo do plano contou com acirrada oposição da comunidade de educadores, organizada no Fórum Nacional em Defesa da Escola Pública (FNDEP), que veicularam, por meio de deputados de oposição, uma propositura alternativa. O resultado final, predominantemente baseado na proposta governamental, contempla um excesso de objetivos e metas, em contraste com a ausência de detalhamento das estratégias e instrumentos pelos quais as metas seriam atingidas e de mecanismos de monitoramento e avaliação dos resultados. Todavia, no tocante às metas e objetivos relativos à profissão docente, não discrepa substancialmente da proposta veiculada pela oposição, exceto pela preocupação com a avaliação da qualidade do trabalho docente.

29. Em 2007, ainda na vigência do PNE 2001/2010, o Governo Federal lançou o Plano de Desenvolvimento da Educação - PDE, designado como um "plano executivo", que, embora não se afastasse inteiramente das metas do PNE, estabelecia um conjunto de programas e linhas de ação que extravasavam a concepção original do plano decenal. O PDE 
não foi veiculado por meio de um diploma jurídico unificado, embora seu programa estratégico tenha sido formulado por meio do Plano de Metas Compromisso Todos pela Educação, formalizada no Decreto $n^{\circ}$ 6.094/2007. Dadas as suas características e processo de formalização, talvez seja melhor caracterizá-lo como um macroprograma governamental, cujos méritos decorrem especialmente do propósito de superar a fragmentação na atuação do MEC e propiciar a articulação interfederativa. Nesse último aspecto, convém destacar os Programas de Ação Articulada - PAR, mecanismo de apoio pactuado entre o MEC e os entes federativos aderentes, por meio do qual, após um diagnóstico das condições locais, são estabelecidas medidas concretas voltadas à consecução de diretrizes consideradas essenciais para a evolução da qualidade da educação básica. Percebe-se que, na elaboração e implementação dos Planos de Ações Articuladas, revela-se de forma mais completa a tecnologia típica do planejamento, destacando-se sua vigência plurianual, de modo a evitar a descontinuidade das ações pactuadas. Registre-se, acerca de seus resultados, que se operou, no período após a implantação do PDE, uma sensível melhora do IDEB, nos anos iniciais e finais do ensino fundamental. No tocante à valorização da profissão docente, porém, é difícil segregar eventual impacto que o PDE tenha causado no tocante à remuneração dos professores de efeitos decorrente do FUNDEB e da Lei do PSPN. Fato é que houve sensível aumento real da remuneração média dos docentes (70\%) no período 2006-2014, superior ao ganho real do salário mínimo - 46\% - e ao ganho real do rendimento médio do brasileiro $44 \%$ - no mesmo período.

30. A poucos dias da expiração do PNE 2001/2010, o Governo Federal encaminhou o projeto do novo PNE. Sua tramitação consumiu três anos e meio, com intensa discussão envolvendo os atores do campo educacional, já mobilizados em razão da primeira Conferência Nacional de Educação - CONAE, ocorrida em 2010. Desse processo resultou a Lei $n^{\circ}$ 13.005/2014, sancionada, sem vetos, pela Presidente DILMA RoUSSEFF, fixando as 20 metas e 246 estratégias do plano. Dentre as principais inovações, destacamos: a meta de alcançar investimento em educação correspondente a 10\% do PIB em 2024, a eleição do Custo Aluno Qualidade - CAQ como parâmetro para financiamento da educação básica e a determinação de regulamentação, no prazo de dois anos, do Sistema Nacional de Educação. No que tange à valorização docente, duas metas são dedicadas ao tema: a Meta 17, que preconiza a equiparação do rendimento médio dos docentes da educação básica aos profissionais com escolaridade equivalente até o ano de 2020; e a Meta 18, que busca assegurar, no prazo de dois anos, a existência de planos de carreira para todos os 
profissionais que atuam na educação pública e, no tocante aos profissionais da educação básica pública, garantir que seus planos de carreira tenham como referência o piso salarial nacional profissional respectivo.

31. Sobre a implementação do PNE 2014/2024, observamos que a eleição de poucas metas, passíveis de mensuração, vem favorecendo o controle social da implementação do plano pelas entidades do setor e impôs ao MEC a divulgação de balanços parciais dos resultados alcançados. Mas, visto que as normas que estipulam as metas são consagradoras de um dever objetivo, ou seja, de um “dever não-relacional” (CANOTILHO, 2003, p. 1267) e destituídas de quaisquer cominações ou processos de responsabilização em face do descumprimento, e dada a conjuntura que se seguiu à promulgação do plano, parece-nos pouco provável que sejam observadas. No tocante à Meta 17, o relatório de monitoramento mais recente do MEC observa que a relação entre profissionais do magistério e outras profissões evoluiu de 65,2\% (2012) para 74,8\% (2017), sendo que, mantida tal trajetória, a meta seria atingida apenas em 2033. Em relação à Meta 18, observa-se enorme dificuldade de monitoramento, em razão da ausência de dados confiáveis acerca da efetiva implantação de planos de carreira e remuneração (PCR) nos Municípios. Para sua implementação, o MEC criou, em 2016, na Secretaria de Articulação como os Sistemas de Ensino (SASE) a Rede de Assistência Técnica dos Planos de Carreira e Remuneração, órgão que desenvolveu instrumentos de diagnósticos dos PCRs, cadernos de orientação e um Sistema de Apoio à Gestão do Plano de Carreira e Remuneração (SisPCR). Em janeiro de 2019, porém, anunciase que o Governo recém-empossado pretende extinguir a referida Secretaria, ${ }^{365}$ o que nos leva a crer que tal esforço de articulação interfederativa será descontinuado, colocando em risco também o Programa de Ações Articuladas - PAR, ação que teve prosseguimento mesmo após o impeachment da Presidente DILMA RouSSEF.

32. Nos últimos anos, o mote principal da agenda educacional tem sido a necessidade de maior coordenação entre os componentes da federação, necessidade que é realçada em 27 estratégias do PNE 2014/2024 e que tem motivado dezenas de proposituras legislativas, buscando estabelecer mecanismos de cooperação interfederativa. Destacamos em nossa pesquisa, duas proposituras: o Projeto de Lei do Senado (PLS) no 337, de 2016, do Senador Cristovam Buarque e o Projeto de Lei da Câmara (PL) nº 1.287/2011, da Professora

${ }^{365}$ Saldaña, Paulo. "Vélez indica para secretarias do MEC ex-alunos de filosofia sem experiência de gestão". Folha de São Paulo, São Paulo, 4 jan. 2019. Disponível em: $<$ https://www1.folha.uol.com.br/educacao/2019/01/velez-indica-para-secretarias-do-mec-ex-alunos-defilosofia-sem-experiencia-de-gestao.shtml>. Acesso em 4 jan. 2019. 
DORINHA SEABRA REZENDE - DEM/TO. O primeiro busca promover a federalização da educação básica, no sentido de permitir que o ente federado transfira a gestão do serviço educacional à União, sendo complementado por outra propositura do mesmo Senador, que cria uma Carreira Nacional do Magistério, com equalização da formação e da remuneração dos professores, selecionados por exigente concurso de âmbito nacional, em regime de dedicação exclusiva e sujeitos a constante avaliação de desempenho. $\mathrm{O}$ segundo projeto busca fixar, por lei federal, as diretrizes para a valorização dos profissionais da educação escolar básica pública, dispondo inclusive sobre os planos de carreira dos docentes em todas as redes de ensino.

33. Para avaliação das propostas e iniciativas voltadas à valorização docente, utilizamos uma primeira grade de análise, construída a partir do trabalho de MARTA ARRETCHE (2012), que leva em consideração as responsabilidades atribuídas à esfera governamental para execução de uma política pública (policy making) e a autonomia para tomar as decisões sobre essa mesma política (policy decision-making), que podem estar associadas ou dissociadas. Assim, distinguem-se três modelos de repartição de responsabilidades: o que concentra em no Governo Central ambas as competências; o que que distribui ambas as competências aos entes subnacionais; e o que concentra, em maior ou menor grau, o policy decision-making na Esfera central de governo e distribui o policy making em âmbito subnacional. Pelo que se pode observar, a propositura do Senador BUARQUE corresponde ao primeiro modelo, que nos parece de baixa viabilidade, seja pela dificuldade política de sua aprovação por Emenda Constitucional, seja pela ausência de medidas relativas ao financiamento dos novos encargos pela União, além da complexidade administrativa da federalização dos quadros. O PL da Deputada Professora DoRinHA SEABRA REZENDE, por sua vez, corresponde ao último modelo, predominante na repartição de competências adotada pelo Constituinte, no âmbito das políticas sociais, não havendo obstáculos evidentes à sua aprovação; porém, as diretrizes propostas não passam de recomendações genéricas desacompanhadas de disposições instrumentais que favoreçam sua implementação.

34. Uma outra grade de análise por nós desenvolvida leva em consideração o tipo de coordenação estabelecida na política pública, num gradiente de quatro tipos: a) absorção (política concentrada); b) direção (política regulatória); c) indução (política de fomento); e d) concertação (política pactuada). Cada um desses tipos apresenta obstáculos e riscos específicos, bem como exige instrumentos adequados para sua veiculação. Destacamos a 
concertação / política pactuada como forma de coordenação adequada ao enfrentamento de problemas e contextos complexos, por meio da constituição de rede de agências governamentais, o que vem sendo estudado como "abordagem governamental integrada" (whole-of-government approach) (CHRISTENSEN; LÆGREID, 2007) ou "gestão pública colaborativa" (collaborative public management) (MCGUIRE, 2006; O'LEARY; VIJ, 2012). O Pacto de Alfabetização na Idade Certa (PAIC) e os Arranjos de Desenvolvimento da Educação (ADE) são exemplos bem sucedidos desse modelo de coordenação, em que o risco de conflitos federativos e judicialização é minorado pela natureza pactuada do ajuste, que também oferece alguns desafios, como a necessidade de superar as assimetrias dos parceiros e promover sua corresponsabilidade.

35. Para construir uma política nacional de carreira docente, é necessário ter em conta determinadas constrições institucionais, a saber: a) limitações normativo-constitucionais, que dizem respeito aos obstáculos procedimentais para o estabelecimento da política - poder de iniciativa, quórum de aprovação, limites formais para a alteração da Constituição - bem como limitações materiais - a intangibilidade do pacto federativo, a preservação de situações consolidadas, a necessidade de se estabelecer regimes de transição, as dificuldades da harmonização de normas estatutárias, etc.; b) limitações histórico-institucionais, que dizem respeito à inércia na trajetória institucional, mantida por força de mecanismos de autorreforço e pelos interesses na manutenção do status quo; nesse tocante, percebe-se que as decisões do Constituinte de 1988 em favor da descentralização da prestação educacional produziram um ambiente institucional favorável à fragmentação de esforços dos entes subnacionais - agravada essa fragmentação pela multiplicação de Municípios de baixa capacidade administrativa e financeira - contrabalançada essa tendência, porém, pela capacidade de coordenação prevista em cláusulas constitucionais ainda não ativadas em toda a sua potencialidade; c) limitações relativas ao financiamento das políticas educacionais, em que se verifica a necessidade do estabelecimento de mecanismos de preservação da disponibilidade financeira - como a vinculação de receitas - e de redistribuição equitativa de recursos, cabendo observar que o dispêndio com pessoal docente representa cerca de $80 \%$ do gasto educacional e corresponde a considerável impacto previdenciário, a ser equacionado.

36. Verifica-se, pelo cenário desenhado, que o estabelecimento de uma política de carreira docente em âmbito nacional exige um esforço de articulação interfederativa, o que seria certamente facilitado pela instituição de um Sistema Nacional de Educação, 
preconizado no art. 214 da Constituição, a partir da redação que lhe foi conferida pela Emenda Constitucional no 59/2009. Tal sistema deve ser construído a partir da noção de regime de colaboração, construído em torno dos seguintes pressupostos: (i) papel central da União na indução da qualidade na educação básica; (ii) autonomia dos Estados e Municípios para a gestão dos seus sistemas; (iii) modelo de financiamento capaz de assegurar um padrão nacional de qualidade; (iv) planejamento decenal articulado entre as três esferas de governo; (v) valorização dos profissionais da educação; e (vi) alinhamento entre currículo, formação de professores e avaliação de aprendizagem (ALMEIDA JR. et al. 2014, p. 116). A implantação efetiva de um Sistema Nacional potencializa a construção de políticas pactuadas que ultrapassem o impasse atual - em que há um conflituoso processo de implantação do PSPN e a frustrada busca de induzir a implantação de PCRs nos entes subnacionais. 


\section{REFERÊNCIAS}

A UNIÃO e o ensino básico. O Estado de São Paulo. São Paulo, 2 out. 2008, p. A3. Disponível em: <https://acervo.estadao.com.br/pagina/\#!/20081002-41988-spo-3-edi-a3not/busca/magist\%C3\%A9rio+lei+ piso>. Acesso em 06 ago 2018.

ABRANCHES, Sérgio. Presidencialismo de coalizão: o dilema institucional brasileiro. Dados: revista de Ciências Sociais, v. 31, n. 1, p. 5-38, 1988.

ABRUCIO, Fernando Luiz. A dinâmica federativa da educação brasileira: diagnóstico e propostas de aperfeiçoamento. Oliveira, Romualdo Portela de; Santana, Wagner (orgs.). Educação e federalismo no Brasil: combater as desigualdades, garantir a diversidade. Brasília: UNESCO, p. 39-70, 2010.

Os barões da federação. Lua Nova: Revista de Cultura e Política, v. 165, n. 33, p. 165-183, 1994.

ABRUCIO, Fernando L.; RAMOS, Mozart N. Regime de colaboração e associativismo territorial: arranjos de desenvolvimento da educação. São Paulo: Fundação Santillana, 2012.

ABRUCIO, Fernando L.; SANO, Hironobu. A experiência de cooperação interestadual no Brasil: formas de atuação e seus desafios. Cadernos Adenauer, v. 12, n. 4, p. 91-110, 2011.

ABRUCIO, Fernando L.; SEGATTO, Catarina Ianni. O manifesto dos pioneiros e o federalismo brasileiro: percalços e avanços rumo a um sistema nacional de educação. In: CUNHA, Célio da; GADOTTI, Moacir; BORDIGNON, Genuíno; NOGUEIRA, Flávia Maria de Barros (org.). O Sistema Nacional de Educação: diversos olhares 80 anos após o Manifesto. Brasília : Ministério da Educação; Secretaria de Articulação com os Sistemas de Ensino, 2014.

ACEMOGLU, Daron; ROBINSON, James. Por que as nações fracassam: as origens do poder, da prosperidade e da pobreza. Tradução Cristiana Serra. Rio de Janeiro: Elsevier Brasil, 2012. Livro eletrônico, não paginado.

ALEXY, Robert. Teoria dos direitos fundamentais. $2^{\mathrm{a}}$ ed. Tradução Virgílio Afonso da Silva. São Paulo: Malheiros, 2014.

ALMEIDA JÚNIOR, Arnóbio Marques de; NOGUEIRA, Flávia Maria de Barros; LAMBERTUCCI, Antônio Roberto; GROSSI JUNIOR, Geraldo. O Sistema Nacional de Educação: em busca de consensos In: CUNHA, Célio da; GADOTTI, Moacir; BORDIGNON, Genuíno; NOGUEIRA, Flávia Maria de Barros (orgs). O Sistema Nacional de Educação: diversos olhares 80 anos após o Manifesto. Brasília : Ministério da Educação; Secretaria de Articulação com os Sistemas de Ensino, 2014.

ALMEIDA, José Ricardo Pires de. História da instrução pública no Brasil 1500-1889. São Paulo: São Paulo Educ/Inep, 2000.

ALVES, Fátima Cristina. Mapeamento das políticas de escolha de diretores da escola e de avaliação na rede pública das capitais brasileiras. Revista Brasileira de Estudos 
Pedagógicos., Brasília, v. 90, n. 224, p. 71-86, jan./abr. 2009. Disponível em: < http://rbep.inep.gov.br/index.php/rbep/article/view/499/483>. Acesso em 20 out. 2018.

AMARAL, Nelson Cardoso. Um novo FUNDEF? as ideias de Anísio Teixeira. Educação \& Sociedade v. XXII, n. 75, p. 277-290, ago 2001.

ANDREWS, Christina W; KOUZMIN, Alexander. O discurso da nova administração pública. Lua Nova v. 45, p. 97-130, 1998.

ANDREWS, Christina ; Bariani, Edison. Administração Pública no Brasil - Breve História Política. São Paulo: Editora Unifesp, 2010.

ANUATTI NETO, Francisco; FERNANDES, Reynaldo; PAZELLO, Elaine T. Avaliação dos salários dos professores da Rede Pública de Ensino Fundamental em tempos de FUNDEF. Revista de Economia Aplicada, v. 8, n. 3, p. 413-437, 2004.

ARAÚJO, Herton; BASSI, Camillo; CODES, Ana; MEIRA, Ana. Quanto custa o Plano Nacional de Educação?: uma estimativa orientada pelo Custo Aluno Qualidade (CAQ). Brasília: IPEA, 2016 (Nota Técnica nº 30).

ARAÚJO, Luiz. O federalismo brasileiro e a aprovação da Emenda Constitucional $n^{\circ} 53$ de 2006. FINEDUCA-Revista de Financiamento da Educação v. 1, 2011.

ARELARO, Lisete Regina Gomes. FUNDEF: uma avaliação preliminar dos dez anos de sua implantação. Reunião Anual da ANPEd, v. 30, 2007.

ARRETCHE, Marta et al. Continuidades e descontinuidades da Federação Brasileira: de como 1988 facilitou 1995. Dados: revista de Ciências Sociais, v. 52, n. 2, p. 377-423, 2009.

ARRETCHE, Marta. Democracia, federalismo e centralização no Brasil. Rio de Janeiro: Editora FGV, Editora FIOCRUZ, 2012.

ARROYO, Miguel Gonzáles. Ofício de mestre: imagens e auto-imagens. $9^{\mathrm{a}}$ ed. Petrópolis: Vozes, 2007.

ASSEMBLEIA NACIONAL CONSTITUINTE. Comissão da Família, da Educação, Cultura e Esportes, da Ciência e Tecnologia e da Comunícaçâo. Centro Gráfico do Senado Federal, jun. 1987, 1987b. Disponível em: <http://www.camara.gov.br/internet/constituicao20anos/DocumentosAvulsos/vol206.pdf>. Acesso em: 24 out. 2017.

1987a. Anteprojeto Constitucional. Brasília: Centro Gráfico do Senado Federal, maio de
Disponível <http://www.camara.gov.br/internet/constituicao20anos/DocumentosAvulsos/vol209.pdf>. Acesso em: 24 out. 2017.

Disponível

Atas das Comissões. Brasília: Centro Gráfico do Senado Federal, julho de 1987b. <http://imagem.camara.gov.br/Imagem/d/pdf/sup95anc16jul1987.pdf\#page=222>. Acesso em: 29 out. 2017. 
Texto Substitutivo do Relator (Segundo). Brasília: Centro Gráfico do Senado Federal, setembro de 1987c. Disponível em: <http://www2.camara.leg.br/atividadelegislativa/legislacao/Constituicoes_Brasileiras/_constituicao-cidada/o-processoconstituinte/comissao-de-sistematizacao/segundo-substitutivo-do-relator>. Acesso em: 24 out. 2017.

AZEVEDO, Clovis Bueno de; LOUREIRO, Maria Rita. Carreiras públicas em uma ordem democrática: entre os modelos burocrático e gerencial. Revista do Serviço Público, Brasília, v. 54, n. 1, p. 47-61, 2014.

AZEVEDO, Fernando et al. A Reconstrução Educacional no Brasil - ao Povo e ao Governo. Revista HISTEDBR On-line. Campinas, n. especial, p.188-204, ago. 2006. Disponível em: <http://www.histedbr.fe.unicamp.br/revista/edicoes/22e/doc1_22e.pdf>. Acesso em 25 jun.2017.

Mais uma vez Convocados: Manifesto ao povo e ao governo (1959). Revista HISTEDBR On-line. Campinas, n. especial, p. 205-220, ago, 2006. Disponível em: <http://www.histedbr.fe.unicamp.br/revista/edicoes/22e/doc2_22e.pdf >. Acesso em: 21 set. 2017.

O Manifesto dos Pioneiros da Educação Nova (1932). Revista Brasileira de Estudos Pedagógicos. Rio de Janeiro, v. 65, n. 150, p. 407-425, mai./ago. 1984. Disponível em: <http://www.histedbr.fe.unicamp.br/revista/edicoes/22e/doc1_22e.pdf>. Acesso em 25 jun.2017.

BACKES, Ana Luiza; AZEVEDO, Débora Bithiah de; ARAÚJO, José Cordeiro de (Orgs) Audiências públicas na Assembleia Nacional Constituinte: a sociedade na tribuna. Brasília: Câmara dos Deputados, Edições Câmara, 2009.

BALLOU, Dale. Test scaling and value-added measurement. Education finance and policy, v. 4, n. 4, p. 351-383, 2009.

BANCO CENTRAL DO BRASIL. Calculadora do Cidadão. Correção de Valores. Disponível em: <https://www3.bcb.gov.br/CALCIDADAO/publico/exibirFormCorrecaoValores.do?metho d=exibirFormCorrecaoValores>. Acesso em 16 nov. 2018.

BARBER, Michael; MOURSHED, Mona. How the world's best-performing systems come out on top. London: McKinsey \& Company, 2007. Disponível em: $<$ https://www.mckinsey.com/industries/social-sector/our-insights/how-the-worlds-bestperforming-school-systems-come-out-on-top> . Acesso em: 26 nov. 2018.

BAREKET-BOJMEL, Liad; HOCHMAN, Guy; ARIELY, Dan. It's (not) all about the Jacksons: Testing different types of short-term bonuses in the field. Journal of Management, v. 43, n. 2, p. 534-554, 2017.

BARRETO, Ângela Maria Rabelo Ferreira. Professores do ensino de primeiro grau: quem são, onde estão e quanto ganham. Estudos em avaliação educacional n. 03, p. 11-43, 1991.

BARROS, Daniel. País mal educado. Rio de Janeiro: Record, 2018. 
BASSI, Camillo de Moraes; ARAÚJO, Herton Ellery; CODES, Ana. FUNDEB e VAA Mínimo Nacional: Critérios Alternativos e Reflexos Sobre a Complementação da União. Nota Técnica. $n^{\circ}$ 44. Brasília: Instituto de Pesquisa Econômica Aplicada- IPEA, nov. 2017. Disponível em: <http://www.ipea.gov.br/portal/index.php?option=com_content\&view=article\&id=31700: nota-tecnica-2017-novembro-numero-44-disoc\&catid=192:disoc\&directory=1>. Acesso em: 11 ago. 2018.

BAUMAN, Zygmunt; BORDONI, Carlo. Estado de crise. Tradução Renato Aguiar. Rio de Janeiro: Zahar,

BAUMGARTNER, Frank R.; JONES, Bryan D. Agenda dynamics and policy subsystems. The journal of Politics, v. 53, n. 4, p. 1044-1074, 1991.

BAUMGARTNER, Frank R.; JONES, Bryan D.; MORTENSEN, Peter B. Punctuated equilibrium theory: Explaining stability and change in public policymaking. Theories of the policy process, v. 8, p. 59-103, 2014.

BEISIEGEL, Celso de Rui. O plano nacional de educação. Cadernos de Pesquisa, n. 106, p. 217-232, 1999.

BENEVOLO, Leonardo. História da cidade. Tradução Silvia Mazza. $2^{a}$ ed. São Paulo: Perspectiva, 1993.

BERCOVICI, Gilberto. Estado, planejamento e direito público no Brasil contemporâneo. In: CARDOSO JR, José Celso (org.); SANTOS, Eugênio A. (org.). PPA 2012-2015: experimentalismo institucional e resistência burocrática. Brasília: IPEA, 2015.

BERCOVICI, Gilberto. O federalismo e o financiamento de políticas sociais no Brasil: uma análise do FUNDEF. Revista Trimestral de Direito Público. 2000. nº 29: 147-61.

BOBBIO, Luigi. La democracia non abita a Gordio: studio sui processi decisionali politico-amministrativi. Milano. FrancoAngeli, 2003.

BONAMINO, Alicia; SOUSA, Sandra Zákia. Três gerações de avaliação da educação básica no. Educação e Pesquisa v. 38, n. 2, p. 373-388, 2012.

BONAVIDES, Paulo. Curso de direito constitucional. $26^{\mathrm{a}}$ ed., atual. São Paulo: Malheiros, 2011.

BONAVIDES, Paulo; ANDRADE, Paes de. História Constitucional do Brasil. $3^{\text {a }}$ ed. Rio de Janeiro: Paz e Terra, 1991.

BORDIGNON, Genuíno; QUEIROZ, Arlindo; GOMES, Lêda. O planejamento educacional no Brasil. Plano Nacional de Educação. Brasília: Fórum Nacional de Educação; Ministério da Educação, 2011.

BOURDIEU, Pierre. Escritos de educação. $5^{\text {a }}$ ed. Petrópolis, RJ: Petrópolis, RJ Vozes, 1998. 
BRASIL. Câmara dos Deputados. Decreto n ${ }^{\circ} 1.331-A$, de 17 de fevereiro de 1854. Approva o Regulamento para a reforma do ensino primario e secundario do Municipio da Côrte. Coleção das Leis do Império do Brasil. 1854. Disponível em: $<$ http://www2.camara.leg.br/legin/fed/decret/1824-1899/decreto-1331-a-17-fevereiro1854-590146-publicacaooriginal-115292-pe.html>. Acesso em: 31.05.2017.

. Câmara dos Deputados. Decreto no 11.530 , de 18 de março de 1915. Reorganiza o ensino secundario e o superior na Republica. Diário Oficial da União. Capital Federal,1915. Seção 1, p. 3028. Disponível em: <http://www2.camara.leg.br/legin/fed/decret/19101919/decreto-11530-18-marco-1915-522019-republicacao-97760-pe.html>. Acesso em 31.05.2017.

Câmara dos Deputados. Decreto ${ }^{\circ} 14.343$, de 7 de setembro de 1920. Institue a Universidade do Rio de Janeiro. Diário Oficial da União, Rio de Janeiro, 1920. Seção 1, p. 15115. Disponível em: <http://www2.camara.leg.br/legin/fed/ decret/1920-1929/decreto14343-7-setembro-1920-570508-publicacaooriginal-93654-pe.html>. Acesso em 31.05.2017.

Câmara dos Deputados. Decreto n ${ }^{\circ} 16.782$-a, de 13 de janeiro de 1925. Estabelece o concurso da União para a diffusão do ensino primario, organiza o Departamento Nacional do Ensino, reforma o ensino secundario e o superior e dá outras providencias. Diário Oficial da União, Rio de Janeiro, 1925. Disponível em: <http://www2.camara.leg.br/legin/fed/decret/1920-1929/decreto-16782-a-13-janeiro-1925517461-publicacaooriginal-1-pe.html>. Acesso em: 18 jun. 2018.

. Câmara dos Deputados. Decreto no 19.402 , de 14 de novembro de 1930. Cria uma Secretária de Estado com a denonimação de Ministério dos Negócios da Educação e Saude Publica. Diário Oficial da União. Rio de Janeiro, 1930. Seção 1, p. 20883. Disponível em: <http://www2.camara.leg.br/legin/ fed/decret/1930-1939/decreto-19402-14-novembro1930-515729-publicacaooriginal-1-pe.html>. Acesso em: 25.06.2017.

Câmara dos Deputados. Decreto no 19.850 , de 11 de Abril de 1931. Crêa o Conselho Nacional de Educação. Diário Official. Rio de Janeiro, 1931a. p. 5799. Disponível em: < http://www2.camara.leg.br/legin/fed/decret/1930-1939/decreto-19850-11-abril-1931515692-publicacaooriginal-1-pe.html>. Acesso em: 04 jan. 2019.

. Câmara dos Deputados. Decreto no 19.890 , de 18 de abril de 1931. Dispõe sobre a organização do ensino secundário. Diário Official. Rio de Janeiro,1931b. p. 6945. Disponível em: <http://www2.camara.leg.br/legin/fed/decret/1930-1939/decreto-19890-18abril-1931-504631-publicacaooriginal-141245-pe.html>. Acesso em 25 jun. 2017.

Câmara dos Deputados. Decreto n ${ }^{\circ} 19.941$, de 30 de abril de 1931. Dispõe sobre a instrução religiosa nos cursos primário, secundário e normal. Diário Oficial da União. Rio de Janeiro, 1931c. Seção 1, p. 7191. Disponível em: <http://www2.camara.leg.br/legin/fed/decret/1930-1939/decreto-19941-30-abril-1931518529-publicacaooriginal-1-pe.html>. Acesso em 25 jun. 2017.

. Câmara dos Deputados. Decreto no 21.335, de 29 de abril de 1932. Instiue a taxa de educação e saude; de duzentos réis sobre todos os documentos sujeitos a selo federal, estadual ou municipal, criando o fundo especial respectivo. Diário Oficial da União. Rio de 
Janeiro, 1932. Seção 1, p. 8689. Disponível em: <http://www2.camara.leg.br/legin/fed/decret/1930-1939/decreto-21335-29-abril-1932504841-publicacaooriginal-1-pe.html>. Acesso em Acesso em 25 jun. 2017.

Câmara dos Deputados. Decreto $n^{\circ} 3.890$, de $1^{\circ}$ de Janeiro de 1901. Approva o Codigo dos Institutos Officiaes de Ensino Superior e Secundario, dependentes do Ministerio da Justiça e Negocios Interiores. Diário Oficial da União. Capital Federal, 1901. Seção 1, p. 4471.- Disponível em: <http://www2.camara.leg.br/legin/fed/decret/1900-1909/decreto3890-1-janeiro-1901-521287-publicacaooriginal-1-pe.html>. Acesso em: 29.05.2018.

Câmara dos Deputados. Decreto no 8.659, de 5 de abril de 1911. Approva a lei Organica do Ensino Superior e do Fundamental na Republica. Diário Oficial da União. Capital Federal, 1911. Seção 1, p. 3983. Disponível em: <http://www2.camara.leg.br/legin/fed/decret/1910-1919/decreto-8659-5-abril-1911517247-publicacaooriginal-1-pe.html>. Acesso em: 31.05.2017.

Câmara dos Deputados. Decreto nº. 71.244, de 11 de outubro de 1972. Estabelece normas para a concessão de auxílio financeiro aos sistemas estaduais de ensino. Diário Oficial da União. Brasília, 1972.Seção 1, p. 9186. Disponível em: <http://www2.camara.leg.br/legin/fed/decret/1970-1979/decreto-71244-11-outubro-1972419670-publicacaooriginal-1-pe.html>. Acesso em 19 jan. 2018.

Câmara dos Deputados. Decreto no. 981, de 8 de novembro de 1890. Approva o Regulamento da Instrucção Primaria e Secundaria do Districto Federal. Coleção de Leis do Brasil. 1890. Vol. Fasc.XI, p. 3474. Disponível em: <http://www2.camara.leg.br/legin/fed/decret/1824-1899/decreto-981-8-novembro-1890515376-publicacaooriginal-1-pe.html> Acesso em: 28.05.2017.

. Câmara dos Deputados. Decreto-lei no 1.202, de 8 de abril de 1939. Dispõe sobre a administração dos Estados e dos Municípios. Diário Oficial da União. Rio de Janeiro, 1939. Seção 1, p. 8113. Disponível em: <http://www2.camara.leg.br/legin/fed/declei/19301939/decreto-lei-1202-8-abril-1939-349366-publicacaooriginal-1-pe.html>. Acesso em 25 jun. 2017.

Câmara dos Deputados. Decreto-lei no 4 958, de 14 de novembro de 1942. Lei Orgânica do Ensino Primário. Diário Oficial da União. Rio de Janeiro, 1946. Seção 1, p.113. Disponível em: <http://www2.camara.leg.br/legin/fed/declei/1940-1949/decreto-lei-85292-janeiro-1946-458442-publicacaooriginal-1-pe.html>. Acesso em 25 jun. 2017.

. Câmara dos Deputados. Decreto-lei no 477, de 26 de fevereiro de 1967. Define infrações disciplinares praticadas por professores, alunos, funcionários ou empregados de estabelecimentos de ensino público ou particulares, e dá outras providências. Diário Oficial da União. Brasília, 1967. Seção 1, p. 1706. Disponível em: <http://www2.camara.leg.br/legin/fed/declei/1960-1969/decreto-lei-477-26-fevereiro1969-367006-publicacaooriginal-1-pe.html>. Acesso em 19 jan. 2018.

Câmara dos Deputados. Decreto-lei no 477, de 26 de fevereiro de 1967. Define infrações disciplinares praticadas por professores, alunos, funcionários ou empregados de estabelecimentos de ensino público ou particulares, e dá outras providências. Diário Oficial da União. Brasília, 1967. Seção 1, p. 1706. Disponível em: 
<http://www2.camara.leg.br/legin/fed/declei/1960-1969/decreto-lei-477-26-fevereiro1969-367006-publicacaooriginal-1-pe.html>. Acesso em 19 jan. 2018.

Câmara dos Deputados. Decreto-lei no 477, de 26 de fevereiro de 1967. Define infrações disciplinares praticadas por professores, alunos, funcionários ou empregados de estabelecimentos de ensino público ou particulares, e dá outras providências. Diário Oficial da União. Brasília, 1967. Seção 1, p. 1706. Disponível em: <http://www2.camara.leg.br/legin/fed/declei/1960-1969/decreto-lei-477-26-fevereiro1969-367006-publicacaooriginal-1-pe.html>. Acesso em 19 jan. 2018.

. Câmara dos Deputados. Diário da Assembleia Nacional Constituinte, Ano I, Suplemento ao $\mathrm{n}^{\mathrm{o}}$ 95, 16 jul. 1987, p. 176-7. Disponível em: <http://imagem.camara.gov.br/Imagem/d/pdf/sup95anc16jul1987.pdf\#page=222>. Acesso em: 29 out. 2017.

. Câmara dos Deputados. Lei Complementar no 7.348, de 24 de julho de 1985. Dispõe sobre a execução do $\S 4^{\circ}$ do art. 176 da Constituição Federal, e dá outras providências. Diário Oficial da União. Brasília, 1985. Seção 1, p. 10651. Disponível em: <http://www2.camara.leg.br/legin/fed/lei/1980-1987/lei-7348-24-julho-1985-356943publicacaooriginal-1-pl.html>. Acesso em 19 jan. 2018.

. Câmara dos Deputados. Lei no 284, de 28 de outubro de 1936. Reajusta os quadros e os vencimentos do funccionalismo publico civil da União e estabelece diversas providencias. Diário Oficial da União. Rio de Janeiro, 1936. Seção 1, Suplemento, p.1. Disponível em: <http://www2.camara.leg.br/legin/fed/lei/1930-1939/lei-284-28-outubro1936-503510-publicacaooriginal-1-pl.html>. Acesso em: 25 jun.2017.

. Câmara dos Deputados. Lei no 4.024, de 20 de dezembro de 1961. Fixa as Diretrizes e Bases da Educação Nacional. Diário Oficial da União. Brasília, 1961.Seção , p. 11429. Disponível em: <http://www2.camara.leg.br/legin/fed/lei/1960-1969/lei-4024-20dezembro-1961-353722-publicacaooriginal-1-pl.html>. Acesso em 25 jun. 2017.

. Câmara dos Deputados. Lei no 5.692, de 11 de agosto de 1971. Fixa Diretrizes e Bases para o ensino de $1^{\circ}$ e $2^{\circ}$ graus, e dá outras providências. Diário Oficial da União. Brasília, 1971. Seção 1, p. 6377. Disponível em: <http://www2.camara.leg.br/legin/fed/lei/1970-1979/lei-5692-11-agosto-1971-357752publicacaooriginal-1-pl.html>. Acesso em 19 jan. 2018.

. Câmara dos Deputados. Lei no 5.692, de 11 de agosto de 1971. Fixa Diretrizes e Bases para o ensino de $1^{\circ}$ e $2^{\circ}$ graus, e dá outras providências. Diário Oficial da União. Brasília, 1971. Seção 1, p. 6377. Disponível em: <http://www2.camara.leg.br/legin/fed/lei/1970-1979/lei-5692-11-agosto-1971-357752publicacaooriginal-1-pl.html>. Acesso em 19 jan. 2018.

Câmara dos Deputados. Lei n ${ }^{\circ}$ 6.871, de 3 de dezembro de 1980. Autoriza o Poder Executivo a instituir a Fundação Centro de Formação do Servidor Público - FUNCEP, e dá outras providências. Diário Oficial da União. Brasília, 1980.Seção 1, p.24347. Disponível em: <http://www2.camara.leg.br/legin/fed/lei/1980-1987/lei-6871-3-dezembro-1980356644-normaatualizada-pl.html>. Acesso em 19 jan. 2018. 
Câmara dos Deputados. Mensagem de 2 de janeiro de 2018. Brasília, 2018. Disponível em: <http://www.camara.leg.br/internet/comissao/index/mista/ orca/orcamento/or2018/lei/Veto13587.pdf>. Acesso em 22 out. 2018.

. Câmara dos Deputados. Mensagem no 449, de 14 de agosto de 2018. Brasília, 2018. Disponível em: <http://www.camara.leg.br/internet/comissao/index/ mista/orca/ldo/LDO2019/Lei_13707/msg_veto.pdf>. Acesso em: 21 out. 2018.

Câmara dos Deputados. Projeto de Lei Complementar n ${ }^{\circ}$ 412/2014. O presente Projeto de Lei Complementar visa responder especificamente às disposições do artigo 23 da Constituição Federal, acelerada, agora, pela recente sanção da Lei no 13.005/2014 que estabelece o Plano Nacional de Educação e dá outras providências. Brasília, 2014. Disponível em: <http://www.camara.gov.br/proposicoesWeb/fichadetramitacao?id Proposicao=620859>. Acesso em: 05 out. 2018.

Câmara dos Deputados. Projeto de Lei no 619/2007. Regulamenta o art. 60, inciso III, alínea "e", do Ato das Disposições Constitucionais Transitórias, para instituir o piso salarial profissional nacional para os profissionais do magistério público da educação básica. Brasília, $2007 . \quad$ Disponível em: <http://www.camara.gov.br/proposicoesWeb/prop_mostrarintegra?codteor=447893\& filename=PL+619/2007> . Acesso em: 05 ago. 2018.

. Câmara dos Deputados. Projeto de Lei no 1.258/88. Fixa as Diretrizes e Bases da Educação Nacional. Diário do Congresso Nacional. Brasília, 1988. Seção I, p. 89-98. Disponível em: <http://imagem.camara.gov.br/diarios.asp?selCodColecaoCsv=J >. Acesso em: 7 mai. 2018.

. Câmara dos Deputados. Projeto de Lei $n^{\circ} 1.287 / 2011$. Estabelece diretrizes para a valorização dos profissionais da educação escolar básica pública. Brasília, 2011b. Disponível em: <http://www.camara.gov.br/proposicoesWeb/fichadetramitacao? idProposicao=501466>. Acesso em: 05 out. 2018.

. Câmara dos Deputados. Projeto de Lei no 5.321, de 2009. Estabelece diretrizes para a valorização dos profissionais da educação escolar básica pública. Brasília, 2009a. Disponível em: <http://www.camara.gov.br/proposicoesWeb/fichadetramitacao? idProposicao $=434662>$. Acesso em 10 out. 2018.

. Câmara dos Deputados. Projeto de Lei n ${ }^{\circ}$ 6.114/2009. Institui o Exame Nacional de Avaliação do Magistério da Educação Básica - Enameb. Brasília, 2009b. Disponível em: <http://www.camara.gov.br/proposicoesWeb/fichadetramitacao?idProposicao $=4527$ 55>. Acesso em: 05 out. 2018.

Câmara dos Deputados. Projeto de Lei no 8.035/2010. Aprova o Plano Nacional de Educação para o decênio 2011-2020 e dá outras providências. Brasília, 2010. Disponível em: <https://www.camara.gov.br/proposicoesWeb/fichadetramitacao? idProposicao= 490116\#marcacao-conteudo-portal>. Acesso em 23 set. 2018.

Câmara dos Deputados. Proposta de Emenda à Constituição 15/2015. Insere parágrafo único no art. 193; inciso IX, no art. 206 e art. 212-A, todos na Constituição Federal, de forma a tornar o Fundo de Manutenção e Desenvolvimento da Educação Básica e de 
Valorização dos Profissionais da Educação - FUNDEB instrumento permanente de financiamento da educação básica pública, incluir o planejamento na ordem social e inserir novo princípio no rol daqueles com base nos quais a educação será ministrada, e revoga o art. 60 do Ato das Disposições Constitucionais Transitórias. Brasília, 2015. Disponível em: <http://www.camara.gov.br/proposicoesWeb/fichadetramitacao? idProposicao=119851>. Acesso em: 22 out. 2018.

. Câmara dos Deputados. Proposta de Emenda Constitucional no 112/99. Modifica os arts. 208, 211 e 212 da Constituição Federal e o art. 60 do Ato das Disposições Constitucionais Transitórias, criando o Fundo de Manutenção e Desenvolvimento da Educação Básica Pública e de Valorização dos Profissionais da Educação. Disponível em: <http://www.camara.gov.br/proposicoesWeb/prop_mostrarintegra;jsessionid= 02A3E6DA4B1201B9B1F81C4364BF6C0D.proposicoesWeb1?codteor=1014814\&filena me=Dossie+-PEC+112/1999>. Acesso em: 23 jul. 2018.

Câmara dos Deputados. Proposta de Emenda à Constituição 415/2005. Dá nova redação ao § 50 do art. 212 da Constituição Federal e ao art. 60 do Ato das Disposições. Brasília, 2005. Disponível em: <http://www.camara.gov.br/proposicoesWeb/prop _mostrarintegra?codteor $=315929 \&$ filename $=$ Tramitacao-PEC $+415 / 2005>$. Acesso em 23 jul. 2018.

. Câmara dos Deputados. Proposta de Emenda à Constituição 539/97. Estabelece que a União complementará os recursos do FUNDEF - Fundo de Manutenção e Desenvolvimento do Ensino Fundamental e de Valorização do Magistério, de modo que seja atingido o valor mínimo por aluno definido nacionalmente e não haja redução do gasto por aluno do ensino fundamental que foi praticado até dezembro do ano de 1997, em cada Município, Estado ou DF. Alterando a Constituição Federal de 1988. Cria o FUNDEB Fundo de Manutenção e Desenvolvimento da Educação Básica e de Valorização dos Profissionais da Educação. Disponível em: <http://www.camara.gov.br/proposicoesWeb/fichadetramitacao?idProposicao=14809>. Acesso em: 23 jul. 2018.

Câmara dos Deputados. Relatório da Comissão de Educação e Desportos, Diário da Câmara dos Deputados. Brasília, 1996. n. 70, p. 10.791 e ss. Disponível em: <http://imagem.camara.gov.br/Imagem/d/pdf/DCD23ABR1996.pdf\#page=254>. Acesso em 21 jun. 2018.

Câmara dos Deputados. Relatório da Comissão Especial da PEC no 536/97. Relatora: Deputada Iara Bernardi. 2005. Disponível em: <http://www.camara.gov.br/proposicoesWeb/prop_mostrarintegra?codteor=360787\&filena me=Tramitacao-PEC+536/1997> . Acesso em: 05 ago. 2018.

Câmara dos Deputados. Relatório. Comissão Especial destinada a proferir parecer à Proposta de Emenda à Constituição n..$^{\circ} 277$-a, de 2008, que "acrescenta $\S 3^{\circ}$ ao art. 76 do ato das disposições constitucionais transitórias para reduzir, anualmente, a partir do exercício de 2009, o percentual da desvinculação de receitas da União incidente sobre os recursos destinados à manutenção e desenvolvimento do ensino de que trata o art. 212 da Constituição Federal. Brasília. Disponível em: <http://www.camara.gov.br/proposicoesWeb/prop_mostrarintegra;jsessionid=F1B540FDA 
F7021B0CA32E7C8B26F9776. proposicoesWebExterno1?codteor $=636747 \&$ filename $=$ Tra mitacao-PEC+277/2008>. Acesso em: 04 nov. 2018.

BRASIL. Constituição (1891) Constituição da República dos Estados Unidos do Brasil. Rio de Janeiro, 1891. Disponível em: <http://www.planalto.gov.br/CCIVIL_03/Constituicao/Constituicao91.htm>. Acesso em: Acesso em 25 jun. 2017.

BRASIL. Constituição (1934) Constituição da República dos Estados Unidos do Brasil. Rio de Janeiro, $1934 . \quad$ Disponível em: <http://www.planalto.gov.br/ccivil_03/Constituicao/Constituicao34.htm>. Acesso em: Acesso em 25 jun. 2017.

BRASIL. Constituição (1937). Constituição dos Estados Unidos do Brasil. Rio de Janeiro, 1937. Disponível em: <http://www.planalto.gov.br/ccivil_03/Constituicao/ Constituicao37.htm>. Acesso em 25 jun. 2017.

BRASIL. Constituição (1946). Constituição dos Estados Unidos do Brasil. Rio de Janeiro, 1946. Disponível em: <http://www.planalto.gov.br/ccivil_03/Constituicao/ Constituicao46.htm>. Acesso em 25 jun. 2017.

BRASIL. Constituição (1967). Constituição dos Estados Unidos do Brasil. Brasília, 1967. Disponível em: <http://www.planalto.gov.br/CCIVIL_03/Constituicao/ Constituicao67.htm>. Acesso em 25 jun. 2017.

Constituição (1967). Constituição dos Estados Unidos do Brasil. Emenda Constitucional ${ }^{\circ}$ 1, de 1969. Edita o novo texto da Constituição Federal de 24 de janeiro de 1967. Brasília, 1969. Disponível em: <http://www.planalto.gov.br/ CCIVIL_03/Constituicao/Emendas/Emc_anterior1988/emc01-69.htm>. Acesso em 25 jun. 2017.

BRASIL. Constituição (1967). Emenda Constitucional $\mathrm{n}^{\circ}$ 24, de 1983. Estabelece a obrigatoriedade de aplicação anual, pela União, de nunca menos de treze por cento, e pelos Estados, Distrito Federal e Municípios, de, no mínimo, vinte e cinco por cento da renda resultante dos impostos, na manutenção e desenvolvimento do ensino. Diário Oficial da União. Brasília, 1983. Seção 1, p. 20465. Disponível em: <http://www2.camara.leg.br/legin/fed/emecon/1980-1987/emendaconstitucional-24-1dezembro-1983-364949-publicacaooriginal-1-pl.html>. Acesso em 19 jan. 2018.

BRASIL. Constituição (1988). Constituição da República Federativa do Brasil. Brasília: DF. Disponível em: <http://www.planalto.gov.br/ccivil_03/constituicao/ constituicao.htm>. Acesso em: 09 jan. 2019.

. Constituição (1988). Emenda Constitucional no 14, de 1996. Modifica os arts. 34, 208, 211 e 212 da Constituição Federal e dá nova redação ao art. 60 do Ato das Disposições Constitucionais Transitórias. Diário da Câmara dos Deputados. Brasília, 1996. p. 2603 Proposta de Emenda à Constituição - PEC no 233/95. Disponível em: <http://www2.camara.leg.br/legin/fed/emecon/1996/emendaconstitucional-14-12setembro-1996-372814-exposicaodemotivos-148871-pl.html>. Acesso em: 05 ago. 2018. 
. Constituição (1988). Emenda Constitucional nº 53, de 19 de dezembro de 2006. Dá nova redação aos arts. $7^{\circ}, 23,30,206,208,211$ e 212 da Constituição Federal e ao art. 60 do Ato das Disposições Constitucionais Transitórias. Diário Oficial da União. Brasília, 2006. Disponível em: <http://www.planalto.gov.br/ccivil_03/constituicao/ Emendas/Emc/emc53.htm/2006>. Acesso em: 05 ago. 2018.

BRASIL. Presidência da República. Ato Institucional no 4 de 7 de dezembro de 1966. Convoca o Congresso Nacional para se reunir extraordináriamente, de 12 de dezembro de 1966 a 24 de janeiro de 1967, para discursão, votação e promulgação do projeto de Constituição apresentado pelo Presidente da República, e dá outras providências. Diário Oficial da União. Brasília, $1966 . \quad$ Disponível em: <http://www.planalto.gov.br/ccivil_03/AIT/ait-04-66.htm>. Acesso em 19 jan. 2018.

. Presidência da República. Lei no 8.666 de 21 de junho de 1993. Regulamenta o art. 37, inciso XXI, da Constituição Federal, institui normas para licitações e contratos da Administração Pública e dá outras providências. Diário Oficial da União. Brasília, 1993. Disponível em: <http://www.planalto.gov.br/ccivil_03/LEIS/L8666cons.htm>. Acesso em 19 jan. 2018.

Presidência da República. Plano Diretor da Reforma do Aparelho do Estado. Brasília, Presidência da República, Câmara da Reforma do Estado. 1995. Disponível em: <http://www.biblioteca.presidencia.gov.br/publicacoes-oficiais/catalogo/fhc/plano-diretorda-reforma-do-aparelho-do-estado-1995.pdf>. Acesso em: 01 mar. 2018.

. Presidência da República. Lei no 9.424 de 24 de dezembro de 1996. Dispõe sobre o Fundo de Manutenção e Desenvolvimento do Ensino Fundamental e de Valorização do Magistério, na forma prevista no art. $60, \S 7^{\circ}$, do Ato das Disposições Constitucionais Transitórias, e dá outras providências. Diário Oficial da União. Brasília, 1996. Seção 1,p. 28442. Disponível em: <http://www2.camara.leg.br/legin/fed/lei/1996/lei-9424-24dezembro-1996-365371-publicacaooriginal-1-pl.html /9>. Acesso em: 01 mar. 2018.

. Presidência da República. Lei no 9.433, de 8 de janeiro de 1997. Institui a Política Nacional de Recursos Hídricos, cria o Sistema Nacional de Gerenciamento de Recursos Hídricos, regulamenta o inciso XIX do art. 21 da Constituição Federal, e altera o art. $1^{\circ}$ da Lei $\mathrm{n}^{\circ}$ 8.001, de 13 de março de 1990, que modificou a Lei $\mathrm{n}^{\circ} 7.990$, de 28 de dezembro de 1989. Diário Oficial da União. Brasília, 1997. Disponível em: <http://www.planalto.gov.br/ccivil_03/leis/L9433.htm>. Acesso em: 01 mar. 2018.

Presidência da República. Lei $n^{\circ}$ 9.494, de 10 de setembro de 1997. Disciplina a aplicação da tutela antecipada contra a Fazenda Pública, altera a Lei $n^{\circ} 7.347$, de 24 de julho de 1985, e dá outras providências. Diário Oficial da União. Brasília, 1997. Disponível em: <http://www.planalto.gov.br/ccivil_03/LEIS/L9494.htm>. Acesso em: 01 mar. 2018.

. Presidência da República. Lei no 9.784, de 29 de janeiro de 1999. Regula o processo administrativo no âmbito da Administração Pública Federal. Diário Oficial da União. Brasília, 1999. Seção 1, p.1. Disponível em: <http://www2.camara.leg.br/legin/fed/lei/1999/lei-9784-29-janeiro-1999-322239retificacao-135464-pl.html>. Acesso em: 01 mar. 2018. 
. Presidência da República. Lei no 10.172, de 9 de janeiro de 2001. Aprova o Plano Nacional de Educação e dá outras providências. Diário Oficial da União. Brasília, 2001. Seção 1, p. 1. Cap. V - Financiamento e gestão, item 11.1, Diagnóstico. Disponível em: <http://www.planalto.gov.br/ccivil_03/ Leis/leis_2001/110172.htm>. Acesso em 23 jul. 2018.

Presidência da República. Lei $n^{\circ} 10.973$, de 2 de dezembro de 2004. Dispõe sobre incentivos à inovação e à pesquisa científica e tecnológica no ambiente produtivo e dá outras providências. Diário Oficial da União. Brasília, 2004. Disponível em: <http://www.planalto.gov.br/ccivil_03/_Ato2004-2006/2004/Lei/L10.973.htm>. Acesso em: 01 mar. 2018.

. Presidência da República. Lei nº 11.107, de 6 de abril de 2005. Dispõe sobre normas gerais de contratação de consórcios públicos e dá outras providências. Brasília, 2012. Disponível em: <http://www.planalto.gov.br/ccivil_03/_Ato20042006/2005/Lei/L11107.htm>. Acesso em: 05 ago. 2018.

. Presidência da República. Decreto nº 6.094, de 24 de maio de 2007. Dispõe sobre a implementação do Plano de Metas Compromisso Todos pela Educação, pela União Federal, em regime de colaboração com Municípios, Distrito Federal e Estados, e a participação das famílias e da comunidade, mediante programas e ações de assistência técnica e financeira, visando a mobilização social pela melhoria da qualidade da educação básica. Diário Oficial da União. Brasília, 2007. Seção 1, p. 5. Disponível em: <http://www2.camara.leg.br/legin/fed/decret/2007/decreto-6094-24-maio-2007-553445publicacaooriginal-71367-pe.html>. Acesso em: 05 ago. 2018.

Presidência da República. Lei $\mathrm{n}^{\circ} 11.494$, de 20 de junho de 2007. Regulamenta o Fundo de Manutenção e Desenvolvimento da Educação Básica e de Valorização dos Profissionais da Educação - FUNDEB, de que trata o art. 60 do Ato das Disposições Constitucionais Transitórias; altera a Lei no 10.195, de 14 de fevereiro de 2001; revoga dispositivos das Leis nos 9.424, de 24 de dezembro de 1996, 10.880, de 9 de junho de 2004, e 10.845, de 5 de março de 2004; e dá outras providências. Diário Oficial da União. Brasília, 2007. Disponível em: <http://www.planalto.gov.br/ccivil_03/_Ato20072010/2007/Lei/L11494.htm>. Acesso em: 05 ago. 2018.

. Presidência da República. Lei $n^{\circ}$ 11.738/2008. Regulamenta a alínea "e" do inciso III do caput do art. 60 do Ato das Disposições Constitucionais Transitórias, para instituir o piso salarial profissional nacional para os profissionais do magistério público da educação básica. Diário Oficial da União. Diário Oficial da União. Brasília, 2008. Disponível em: <http://www.planalto.gov.br/ccivil_03/_ato2007-2010/2008/lei/111738.htm>. Acesso em: 05 ago. 2018.

Presidência da República. Decreto no 6.755, de 29 de janeiro de 2009. Institui a Política Nacional de Formação de Profissionais do Magistério da Educação Básica, disciplina a atuação da Coordenação de Aperfeiçoamento de Pessoal de Nível Superior CAPES no fomento a programas de formação inicial e continuada, e dá outras providências. Diário Oficial da União. Brasília, 2009. Seção 1, p. 1. Disponível em: < http://www.planalto.gov.br/ccivil_03/_Ato2007-2010/2009/Decreto/D6755.htm>. Acesso em: 05 ago. 2018. 
. Presidência da República. Lei no 12.014, de 6 de agosto de 2009. Altera o art. 61 da Lei no 9.394, de 20 de dezembro de 1996, com a finalidade de discriminar as categorias de trabalhadores que se devem considerar profissionais da educação. Diário Oficial da União. Brasília, 2009.2 Disponível em: <http://www.planalto.gov.br/ccivil_03/_Ato20072010/2009/Lei/L12014.htm>. Acesso em: 05 ago. 2018.

. Presidência da República. Lei n ${ }^{\circ} 12.305$, de 2 de agosto de 2010. Institui a Política Nacional de Resíduos Sólidos; altera a Lei no 9.605, de 12 de fevereiro de 1998; e dá outras providências. Diário Oficial da União. Brasília, 2010. Disponível em: <http://www.planalto.gov.br/ccivil_03/_ato2007-2010/2010/lei/112305.htm>. Acesso em: 19 de setembro de 2018.

Presidência da República. Lei no 12.587 , de 3 de janeiro de 2012. Institui a Política Nacional de Resíduos Sólidos; altera a Lei no 9.605, de 12 de fevereiro de 1998; e dá outras providências. Diário Oficial da União. Brasília, 2012. Disponível em: <http://www.planalto.gov.br/ccivil_03/_ato2007-2010/2010/lei/112305.htm>. Acesso em: 19 de setembro de 2018.

Presidência da República. Lei no 13.005 , de 25 de junho de 2014. Aprova o Plano Nacional de Educação - PNE e dá outras providências. Diário Oficial [da] República Federativa do Brasil, Brasília, DF, 26 jun. 2014. Disponível em: <http://www.planalto.gov.br/ccivil_03/_Ato2011-2014/2014/Lei/L13005.htm>. Acesso em: 19 de setembro de 2018 .

Presidência da República. Lei $n^{\circ} 13.473$, de 8 de agosto de 2017. Dispõe sobre as diretrizes para a elaboração e execução da Lei Orçamentária de 2018 e dá outras providências. Diário Oficial da União. Brasília, 2017. Seção 1, p. 44. Disponível em: <http://www.planalto.gov.br/ccivil_03/_ato2015-2018/2017/lei/L13473.htm>. Acesso em: 19 de setembro de 2018.

. Presidência da República. Programas de programa de metas do presidente Juscelino Kubitschek. Rio de Janeiro, 1958. Disponível em: $<$ https://www.google.com/url?sa=t\&rct=j\&q=\&esrc=s\&source=web\&cd=1\&ved=2ahUKE wirwcCc8KjdAhXLjJAKHSERBLgQFjAAegQIABAC\&url=http\%3A\%2F\%2Fbibspi.pla nejamento.gov.br\%2Fbitstream\%2Fhandle $\% 2$ Fiditem $\% 2$ F490\%2FPrograma $\% 2520 \mathrm{de} \% 25$ 20Metas\%2520do\%2520Presidente\%2520Puscelino\%2520Kubitschek\%2520V1\%252019 50_PDF_OCR.pdf\%3Fsequence\%3D1\%26isAllowed\%3Dy\&usg=AOvVaw3ON2J19sVbXVSsM7GXjJm>. Acesso em: 07 set. 2018.

BRASIL. Ministério da Educação. Parecer CNE/CEB nº 10, de 3 de setembro de 1997. Diretrizes para os Novos Planos de Carreira e Remuneração do Magistério dos Estados, do Distrito Federal e dos Municípios. Diário Oficial da União. Brasília, 1997. Disponível em: $<$ http://redir.stf.jus.br/paginadorpub/paginador.jsp?docTP=TP\&docID=14474659>. Acesso em: 23 jun. 2018.

. Ministério da Educação. Plano Nacional de Alfabetização e Cidadania: marcos de referência. Brasília, 1991. Disponível em: <http://www.dominiopublico.gov.br/ download/texto/me000684.pdf>. Acesso em 04 ago. 2018. 
Ministério da Educação. Portaria Normativa n ${ }^{\circ} 9$ de 30 de junho de 2009. Institui o Plano Nacional de Formação dos Professores da Educação Básica no âmbito do Ministério da Educação. Diário Oficial da União. Brasília, 2009. p. 9. Disponível em: <http://portal.mec.gov.br/dmdocuments/port_normt_09_300609.pdf >. Acesso em: 23 jun. 2018.

. Ministério da Educação. Resolução CNE - CEB nº 01, de 23 de janeiro de 2012. Dispõe sobre a implementação do regime de colaboração mediante Arranjo de Desenvolvimento da Educação (ADE), como instrumento de gestão pública para a melhoria da qualidade social da educação. Brasília, 2012. Disponível em: <http://portal.mec.gov.br/index.php?option=com_docman\&view=download\&alia s=9816rceb001-12\&Itemid=30192> . Acesso em: 9 nov. 2018.

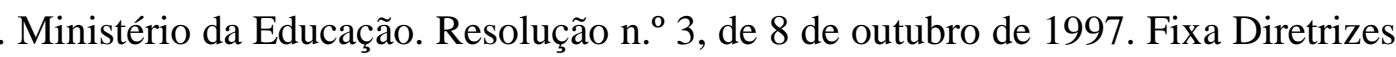
para os Novos Planos de Carreira e de Remuneração para o Magistério dos Estados, do Distrito Federal e dos Municípios. Diário Oficial da União. Brasília, 1997. Seção 1, p. 22987. Disponível em: <http://portal.mec.gov.br/cne/arquivos/pdf/CEB0397.pdf>. Acesso em: 23 jul. 2018.

. Ministério da Educação. Resolução nº 2, de 28 de maio de 2009. Fixa as Diretrizes Nacionais para os Planos de Carreira e Remuneração dos Profissionais do Magistério da Educação Básica Pública, em conformidade com o artigo $6^{\circ}$ da Lei ${ }^{\circ} 11.738$, de 16 de julho de 2008, e com base nos artigos 206 e 211 da Constituição Federal, nos artigos $8^{\circ}$, $\S 1^{\circ}$, e 67 da Lei $n^{\circ}$ 9.394, de 20 de dezembro de 1996, e no artigo 40 da Lei no 11.494 , de 20 de junho de 2007. Diário Oficial da União. Brasília, 2007. Seção 1, p. 41 e 42. Disponível em: <http://portal.mec.gov.br/dmdocuments/resolucao_cne_ceb002_2009.pdf >. Acesso em: 10 out. 2018.

BRASIL. Senado Federal. Diário do Congresso Nacional. Brasília, 1994. Seção II, (Senado Federal), 6 de dezembro de 1994, p. 7906-7919. Disponível em: <http://legis.senado.leg.br/diarios/PublicacoesOficiais>. Acesso em: 7 mai. 2018.

Senado Federal. Projeto de Lei do Senado no 59, de 2004. Autoriza o Poder Executivo a instituir o Piso Salarial Profissional dos Educadores Públicos, na forma prevista no art. 206, V, e 212 da Constituição Federal e dá outras providências. Diário do Senado Federal. Brasília, 2004. p. 24. Disponível em: $<$ http://legis.senado.leg.br/diarios/BuscaDiario?tipDiario=1\&datDiario=24/03/2004 \&paginaDireta $=08064>$. Acesso em: 05 ago. 2018.

Senado Federal. Projeto de Lei da Câmara $n^{\circ}$ 103, de 2012. Aprova o Plano Nacional de Educação - PNE e dá outras providências. Brasília, 2012. Disponível em: <https://www25.senado.leg.br/web/atividade/materias/-/materia/108259>. Acesso em: 23 set. 2018.

Senado Federal. Projeto de Lei do Senado ${ }^{\circ} 337$, de 2016 (complementar). Dispõe sobre instrumento de cooperação federativa para transferência à União de competências educacionais de Estados, Distrito Federal e Municípios. Brasília, 2016. Disponível em: <https://www25.senado.leg.br/web/atividade/materias/-/materia/126890>. Acesso em: 05 out. 2018. 
. Senado Federal. Proposta de Emenda à Constituição n 24, de 2017. Acrescenta o art. 212-A à Constituição Federal, para tornar permanente o Fundo de Manutenção e Desenvolvimento da Educação Básica e de Valorização dos Profissionais da Educação FUNDEB, e revoga o art. 60 do Ato das Disposições Constitucionais Transitórias. Brasília, 2017. Disponível em: <https://www25.senado.leg.br/web/atividade/materias//materia/129778>. Acesso em: 22 out. 2018.

Senado Federal. Projeto de Lei da Câmara n 88, de 2018. Estabelece diretrizes para a valorização dos profissionais da educação escolar básica pública. Brasília, 2018. Disponível em: <https://www25.senado.leg.br/web/atividade/materias/-/materia/134084>. Acesso em: 05 out. 2018.

Bases da Assembleia Nacional Constituinte 1987-1988. Disponível em:

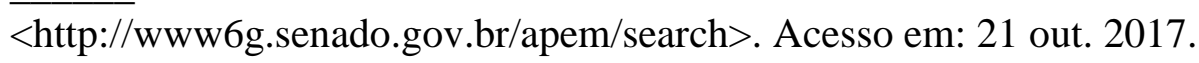

BRASIL. Superior Tribunal de Justiça. REsp: 1426210 RS 2013/0416797-6, Relator: Ministro Gurgel de Faria, Data de Julgamento: 23/11/2016, S1 - Primeira Seção, Data de Publicação: DJe 09/12/2016. Disponível em: <https://ww2.stj.jus.br/processo/revista/inteiroteor/?num_registro=201304167976\&dt_publ icacao=09/12/2016>. Acesso em: 11 ago. 2018.

Superior Tribunal de Justiça. REsp: 1426210 RS 2013/0416797-6, Relator: Ministro Gurgel De Faria, Data de Julgamento: 23/11/2016, S1 - Primeira Seção, Data de Publicação: DJe 09/12/2016. Disponível <https://ww2.stj.jus.br/processo/revista/inteiroteor/?num_registro $=201304167976 \& d t \_$publicacao=09/12/2016> . Acesso em: 11 ago. 2018.

BRASIL. Supremo Tribunal Federal. Andamento do Processo n. 1.149 - Medida Cautelar / Suspensão de Liminar - 04/05/2018 do STF. Relator(a): Ministra Cármen Lúcia. Julgado em 13/04/2018, publicado em processo eletrônico dje-087 divulg 04/05/2018 public 07/05/2018. disponível em: <http://www.stf.jus.br/portal/jurisprudencia/ visualizarEmenta.asp?s1=000423337\&base=basePresidencia $>$. Acesso em: 11 ago. 2018.

Supremo Tribunal Federal. ADI 2.135 MC, Pleno, Rel. p/ o acórdão Min. Ellen Gracie, j. 2-8-2007, DJE de 7-3-2008, 2007. Disponível em: $<$ http://redir.stf.jus.br/paginadorpub/ paginador.jsp?docTP=AC\&docID=513625>. Acesso em: 04 nov. 2017.

Supremo Tribunal Federal. n. 1.149 - Medida Cautelar / Suspensão de Liminar 04/05/2018 do STF. Relator(a): Ministra Cármen Lúcia. Julgado em 13/04/2018, publicado em processo eletrônico dje-087 divulg 04/05/2018 public 07/05/2018. Disponível em: <http://www.stf.jus.br/portal/jurisprudencia/visualizarEmenta.asp?s1=000423337\&base=b asePresidencia>. Acesso em: 11 ago. 2018.

BRASIL. Tribunal Superior do Trabalho. Súmula no 390. Estabilidade. Art. 41 da Cf/1988. Celetista. Administração Direta, Autárquica ou Fundacional. Aplicabilidade. Empregado de Empresa Pública de Sociedade de Economia Mista. Inaplicável (conversão das Orientações Jurisprudenciais n's $^{\circ} 29$ e 265 da SBDI-1 e da Orientação Jurisprudencial n ${ }^{\circ} 22$ da SBDI-2) - Res. 129/2005, DJ 20, 22 e 25.04.2005, 2005. Disponível em: 
<http://www3.tst.jus.br/jurisprudencia/Sumulas_com_indice/

Sumulas_Ind_351_400.html\#SUM-390>. Acesso em: 11 ago. 2018.

BREMAEKER, François Eugene Jean de. A política de fundos para a educação e o impacto nas finanças dos estados e dos municípios. In: GOUVEIA, Andréa Barbosa (org.) PINTO, José Marcelino Rezende (org.) Paulo Roberto Corbucci (org.). Federalismo e políticas educacionais na efetivação do direito à educação no Brasil. 52-68. Brasília: IPEA, 2011.

BRZEZINSKI, Iria (org.). LDB/1996: uma década de perspectivas e perplexidades na formação de profissionais da educação. LDB dez anos depois: reinterpretações sob diversos olhares. São Paulo: Cortez, p. 167-194, 2008.

BUARQUE, Cristovam. A Revolução Republicana na Educação. São Paulo: Moderna, 2011.

BUCCI, Mara Paula Dallari. Contribuição para a redução da judicialização da saúde: uma estratégia jurídico-institucional baseada na abordagem de direito e políticas públicas. In: BUCCI Maria Paula Dallari; DUARTE, Clarice Seixas (coord.) Judicialização da saúde: a visão do Poder Executivo. São Paulo: Saraiva, p. 31-88, 2017.

Direito administrativo e políticas públicas. São Paulo, Saraiva, 2002.

Fundamentos para uma teoria jurídica das políticas públicas. São Paulo: Editora Saraiva, 2013.

BUCCI, Maria Paula Dallari; VILARINO, Marisa Alves. A ordenação federativa da Educação brasileira e seu impacto sobre a formação e o controle das políticas públicas educacionais. In: ABMP; TODOS PELA EDUCAÇÃO. Justiça pela qualidade na Educação. São Paulo: Saraiva, p. 117-150, 2013.

CAMARGO, Rubens Barbosa de Camargo. Efeitos do FUNDEB e do PSPN em vencimentos de docentes de redes estaduais do brasil (2006-2014). In: OLIVEIRA, João Ferreira (org.). Anais do VI Congresso Ibero-Americano e IX Congresso LusoBrasileiro de Política e Administração da Educação. Recife: ANPAE, p. 367-370, 2018. [Livro Eletrônico]. Disponível em: <http://www.anpae.org.br/IBERO2018/ publicacao.html>. Acesso em: 16 set. 2018.

CAMINI, Lucia. A política educacional do PDE e do Plano de Metas Compromisso Todos pela Educação. Revista Brasileira de Política e Administração da Educação - ANPAE, v.26, n.3, p. 535-550, set./dez. 2010.

CANOTILHO, José Joaquim Gomes Direito constitucional e teoria da constituição. $7^{\mathrm{a}} \mathrm{ed}$. Coimbra: Almedina, 2003.

CAPANEMA. Gustavo. Exposição de motivos do Decreto-lei $\mathbf{n}^{\mathbf{0}} \mathbf{4 . 2 4 4}$, de 9 de abril de 1942. Lei orgânica do ensino secundário. Disponível em: <http://www2.camara.leg.br/legin/fed/declei/1940-1949/decreto-lei-4244-9-abril-1942414155-133712-pe.html>. Acesso em: 19 ago. 2017. 
CARA, Daniel. Municípios no pacto federativo: fragilidades sobrepostas. Retratos da Escola, v. 6, n. 10, p. 255-273, 2012.

. O Custo Aluno-Qualidade Inicial como proposta de justiça federativa no PNE: Um primeiro passo rumo à educação pública de qualidade no Brasil. Jornal de Políticas Educacionais v. 8, n. 16, 2014.

CARDOSO JR, José Celso (org.); SANTOS, Eugênio A. (org.). PPA 2012-2015: experimentalismo institucional e resistência burocrática. Brasília: IPEA, 2015. (Série: Pensamento estratégico, planejamento governamental \& desenvolvimento no Brasil contemporâneo - Livro 2).

CARDOSO JR., José Celso (org.). A reinvenção do planejamento governamental no Brasil. Brasília: IPEA, 2011 (Série: Diálogos para o Desenvolvimento, v. 4).

Estado, planejamento, gestão e desenvolvimento. Balanço da experiência brasileira e desafios no século XXI. Santiago: CEPAL, 2014.

CARVALHO FILHO, José dos Santos. Direito Administrativo. $27^{\mathrm{a}}$ ed. rev. atual. e ampl. São Paulo: Atlas, 2014.

CARVALHO, Luiz Maklouf. 1988: Segredos da Constituinte. Rio de Janeiro: Record, 2017.

. A crise do Estado. Tradução Ilse Paschoal Moreira, Fernanda Landucci Ortale. São Paulo: Saberes Editora, 2010.

CASSINI, Simone Alves. Associativismo territorial na educação: novas configurações da colaboração e cooperação federativa. Tese (Doutorado em Educação) Programa de PósGraduação em Educação do Centro de Educação, Universidade Federal do Espírito Santo UFES, Vitória, 2016. Disponível em: <http://repositorio.ufes.br/ jspui/handle/10/8558>. Acesso em: 09 nov. 2018.

CASTOR, Belmiro Valverde Jobim. O Brasil não é para amadores: estado, governo e burocracia na terra do jeitinho. 2a. ed. rev. e atual. Curitiba: Travessa dos Editores, 2004.

CASTRO, Conrado Pires de. Luiz Pereira e sua circunstância: entrevista com José de Souza Martins. Tempo social, v. 22, n. 1, p. 211-276, 2010.

CERASOLI, Christopher P.; NICKLIN, Jessica M.; FORD, Michael T. Intrinsic motivation and extrinsic incentives jointly predict performance: A 40-year meta-analysis. Psychological bulletin, v. 140, n. 4, p. 980, 2014.

CHANG, Ha-Joon. 23 coisas que não nos contaram sobre o capitalismo. São Paulo: Editora Cultrix, 2013. Livro eletrônico, não paginado.

CHETTY, Raj; FRIEDMAN, John N.; ROCKOFF, Jonah E. Measuring the impacts of teachers I: Evaluating bias in teacher value-added estimates. American Economic Review, v. 104, n. 9, p. 2593-2632, 2014. 
CHRISTENSEN, Tom; LÆGREID, Per. The whole-of-government approach to public sector reform. Public administration review, v. 67, n. 6, p. 1059-1066, 2007.

COELHO, João Gilberto Lucas. Processo Constituinte, Audiências Públicas e o nascimento de uma nova ordem. In: BACKES, Ana Luiza; AZEVEDO, Débora Bithiah; ARAÚJO, José Cordeiro de (Orgs.). Audiências Públicas na Assembléia Nacional Constituinte. A sociedade na tribuna. Brasília: Edições Câmara, 2009.

COHEN, Michael D.; MARCH, James G.; OLSEN, Johan P. A garbage can model of organizational choice. Administrative science quarterly, p. 1-25, 1972.

COLISTETE. Renato P. Iniciativas Educacionais e Mobilização por Escolas Primárias em São Paulo, 1830-1889. Working Paper Series, no 4/2017. São Paulo: Faculdade de Economia e Administração da Universidade de São Paulo, 2017.

CONFERÊNCIA NACIONAL DE EDUCAÇÃO - II CONED. Plano Nacional de Educação: a proposta da Sociedade Brasileira. Brasília: CONED, 1997. Disponível em: $<$ http://www.fedepsp.org.br/documentos/PNE\%20-\%20proposta\%20da\%20 sociedade\%20brasileira.pdf $>$. Acesso em: 06 jan. 2019.

CONFEDERAÇÃO NACIONAL DOS TRABALHADORES DA EDUCAÇÃO. Piso e Carreira andam juntos. Brasília: CNTE. 2015. Disponível em: <http://www.cnte.org.b r/images/stories/publicacoes/cartilha_piso_e_carreira_andam_juntos.pdf $>$. Acesso em: 08 jan. 2019.

CONFERÊNCIA NACIONAL DE EDUCAÇÃO (CONAE), 2010, Brasília, DF. Construindo o Sistema Nacional articulado de Educação: o Plano Nacional de Educação, diretrizes e estratégias; Documento Final. Brasília, DF: MEC, 2010b. 164p. Disponível em: <http://pne.mec.gov.br/images/pdf/CONAE2010_doc_final.pdf>. Acesso em: 22 set. 2018.

CORBUCCI, Paulo Roberto; BARRETO, Ângela; CASTRO, Jorge Abrahão de; CHAVES, José Valente; CODES, Ana Luiza Codes. Vinte anos da Constituição Federal de 1988: avanços e desafios na educação brasileira. In: Políticas sociais: acompanhamento e análise, Brasília: IPEA, v. 2, n. 17, P. 17-84, 2009.

COSTA, Frederico Lustosa da. História das reformas administrativas no Brasil: narrativas, teorizações e representações. Revista do Serviço Público v. 59, n. 3, p. 271 , 2008.

COUTINHO, Diogo R. O direito nas políticas públicas. MARQUES, Eduardo; FARIA, Carlos Aurélio Pimenta de (Orgs.). A política pública como campo multidisciplinar, p. 181-200, 2013.

CRAWFORD, Sue E. S.; OSTROM, Elinor. A grammar of institutions. American Political Science Review, v. 89, n. 3, p. 582-600, 1995.

CUNHA, Célio da. A política de valorização do magistério na década de 1990: apontamentos incompletos. Caminhos da profissionalização do magistério. Campinas: Papirus Editora, 1998. p. 49-74. 
CUNHA, Célio da; GADOTTI, Moacir; BORDIGNON, Genuíno; NOGUEIRA, Flávia Maria de Barros (orgs). O Sistema Nacional de Educação: diversos olhares 80 anos após o Manifesto. Brasília: Ministério da Educação; Secretaria de Articulação com os Sistemas de Ensino, 2014.

CURY, Carlos Roberto Jamil. A desoficialização do ensino no Brasil: a Reforma Rivadávia. Educação e Sociedade, Campinas, V. 30, N. 108, P. 717-738, 2009. jan./dez. 2012.

Lei de responsabilidade educacional. Direito e Sociedade. Catanduva, v. 7, n. 1, . O plano nacional de educação: duas formulações. Cadernos de Pesquisa, n. 104, p. 162-180, 1998.

BALLOU, Dale. Test scaling and value-added measurement. Education finance and Policy, V. 4, N. 4, P. 351-383, 2009. Disponível em: <https://my.vanderbilt.edu/ performanceincentives/supplemental-studies/value-added-studies/test-scaling-and-valueadded-measurement/>. Acesso em: 05 mai. 2018.

DARCY critica magistério. O Estado de São Paulo. São Paulo, 26 jun. 1995, p. A-14., Disponível em: <http://acervo.estadao.com.br/pagina/\#!/19950626-37140-nac-0014-gera14-not>. Acesso em 17 jun. 2018.

DAVIES, Nicholas. A confiabilidade dos órgãos de controle das verbas da educação. Em Aberto v. 28, n. $93,2015$.

.O financiamento da educação estatal no Brasil: novos ou velhos desafios. Revista Educação On-line PUC-Rio. Rio de Janeiro, nº 10: 31-63, 2012.

DE BRUYCKER, Philippe. 12a-L'intercommunalité en Europe. Quelques observations à propos de la France au regard de quelques Etats Européens. Annuaire des collectivités locales, v. 20, n. 1, p. 159-165, 2000.

DECI, Edward L.; OLAFSEN, Anja H.; RYAN, Richard M. Self-determination theory in work organizations: the state of a science. Annual Review of Organizational Psychology and Organizational Behavior, v. 4, p. 19-43, 2017.

DEFFIGIER, Clotilde. Intercommunalité et territorialisation de l'action publique en Europe. Revue française d'administration publique, n. 121-122, p. 79-98, 2007.

DENHARDT, Robert B. Teorias da Administração Pública. Tradução Francisco G. Heidemann. $1^{a}$ ed. Brasileira (tradução da $6^{a}$ ed. norte-americana). São Paulo: Cengage Learning, 2012.

DeSEnVolvimento DA EDUCAÇÃO. O Estado de São Paulo, São Paulo, 26 abr. 2007, p. A3. Disponível em:< https://acervo.estadao.com. br/>. Acesso em: 16 set. 2018.

DI GIOVANNI, Geraldo; NOGUEIRA, Marco Aurélio (orgs). Dicionário de políticas públicas. $2^{\mathrm{a}}$ ed. São Paulo: FUNDAP; Editora UNESP, 2015. 
DI PIETRO, Maria Sylvia Zanella. Direito Administrativo. $30^{\mathrm{a}}$ ed. rev. atual. e ampl. Rio de Janeiro: Forense, 2017.

DOLTON, Peter; MARCENARO-GUTIERREZ, Oscar; DE VRIES, Robert; SHE, Po-Wen. Global Teacher Status Index 2018. London: Varkey Foundation, 2018. Disponível em: <https://www.varkeyfoundation.org/media/4867/gts-index-13-11-2018.pdf>. Acesso em: 26 nov. 2018.

DROMI, José Roberto. Derecho administrativo. $12^{\mathrm{a}}$ ed. Buenos Aires/Madrid/México: Ciudad Argentina/Hispana Libros, 2009.

DROR, Yehezkel. Gobernabilidad, participación y aspectos sociales de la planificación. Revista de la CEPAL, 1987.

. Muddling Through - "Science" or Inertia? Public administration review, vol. 24, no. 3, p. 153-157, 1964.

ETZIONI, Amitai. Mixed-scanning: A "third" approach to decision-making. Public administration review, p. 385-392, 1967.

FAORO, Raymundo. Os donos do poder. 10a ed. São Paulo: Globo; Publifolha, 2000. 2 v.

FERNANDES, Ciro Campos Christo; PALOTTI, Pedro Lucas de Moura; CAMÕES, Marizaura Reis de Souza. Escolas de governo: perfis, trajetórias e perspectivas. Brasília: ENAP 2015. (Cadernos ENAP, 43, vol. I).

FERNANDES, Fabiana Silva; GENTILINI, João Augusto. Planejamento, políticas públicas e educação. Cadernos de Pesquisa, v. 44, n. 153, p. 486-492, 2014.

FERNANDES, Florestan. Diretrizes e bases: conciliação aberta. Universidade e sociedade v. 01, p. 33-36, 1991.

FERNANDES, Francisco das Chagas: entrevista. [27 set. 2010] Educação \& Sociedade. Campinas, v. 31, n. 112, p. 1031-1058, jul.-set. 2010.

FERNANDES, Reynaldo; GREMAUD, Amaury Patrick. Qualidade da educação: avaliação, indicadores e metas. Educação básica no Brasil: construindo o país do futuro. Rio de Janeiro: Elsevier v. 1, p. 213-238, 2009.

FERNANDES, Reynaldo; GREMAUD, Amaury Patrick. Qualidade da educação: FERNÁNDEZ ENGUITA, Mariano. O magistério numa sociedade em mudança. ALENCASTRO VEIGA, Ilma Passos (Org.). Caminhos da profissionalização do magistério. Campinas: Papirus, 1998.

FERREIRA FILHO, Manoel Gonçalves. Curso de direito constitucional. 40ª edição, São Paulo: Saraiva, 2015.

FERREIRA JR, Amarilio; BITTAR, Marisa. A ditadura militar e a proletarização dos professores. Educação \& Sociedade v. 27, n. 97 , 2006. 
FERREIRA, Jorge. URSS: mito, utopia e história. Tempo, Rio de Janeiro, vol. 3, n 5, p. 75 $-103,1998$.

FIGUEIREDO, Argelina; LIMONGI, Fernando. Bases institucionais do presidencialismo de coalizão. Lua Nova, v. 44, p. 81-106, 1998.

FLEURI, Reinaldo Matias. Perfil profissional docente no Brasil metodologias e categorias de pesquisa. Brasília: INEP, 2015. (Série Documental: Relatos de Pesquisa 40). Disponível em: <http://portal.inep.gov.br/informacao-da-publicacao/-/asset_publisher/ 6JYIsGMAMkW1/document/id/493895>. Acesso em: 23 nov. 2018.

FÓRUM NACIONAL EM DEFESA DA ESCOLA PÚBLICA. Plano Nacional de Educação: proposta da sociedade brasileira. In: CONGRESSO Nacional de Educação, 2, 1997, Belo Horizonte. Disponível em: <http://www.fedepsp.org.br/documentos/PNE\%2020proposta\%20da\%20sociedade\% 20brasileira.pdf $>$. Acesso em: 10 set. 2018.

FREITAS, Janio de. Projeto nasceu 'Frankenstein' e virou 'Hércules'. Vide, a propósito, o ofício de esclarecimento encaminhado pela Presidência da Comissão, disponível em: <http://www.camara.gov.br/internet/constituicao20anos/DocumentosAvulsos/vol206.pdf>. Acesso em: 24 out. 2017.

FREITAS, Marcos Cezar de; BICCAS, Maurilane de Souza. 2009. História social da educação no Brasil (1926-1996). São Paulo: São Paulo Cortez.

FUNDAÇÃO VICTOR CIVITA; FUNDAÇÃO CARLOS CHAGAS. Estudos \& Pesquisas Educacionais, n. 1. São Paulo: Fundação Victor Civita, 2010. Disponível em: <htps://abrilfundacaovictorcivita.files.wordpress.com/2018/04/estudos_e_pesquisas_educa cionais_vol_1.pdf>. Acesso em: 24 nov. 2018.

GADOTTI, Moacir. Convocados, uma vez mais: ruptura, continuidade e desafios do PDE. São Paulo: Instituto Paulo Freire, 2008.

Da palavra a ação. INEP. Educação para todos: a avaliação da década. Brasília: MEC/INEP, p. 27-31, 2000.

GARCÍA de Enterría, Eduardo. FERNÁNDEZ, Tomás-Ramón. Curso de direito administrativo. Tradutor José Alberto Froes Cal. São Paulo: Revista dos Tribunais, 2015. $2 \mathrm{v}$.

GATTI, Bernadete; BARRETTO, Elba Siqueira de Sá (Orgs.). Professores do Brasil: impasses e desafios. Brasília: UNESCO, 2009. 294 p. Disponível em: <http://unesdoc.unesco.org/images/0018/001846/184682por.pdf>. 85-7652-108-3.

GATTI, Bernadete; BARRETTO, Elba Siqueira de Sá; ANDRÉ, Marli Eliza Dalmazo de Afonso. Políticas docentes no Brasil: um estado da arte. Brasília: UNESCO, 2011.

GATTI, Bernardete A. Reconhecimento social e as políticas de carreira docente na educação básica. Cadernos de pesquisa, v. 42, n. 145, p. 88-111, 2012. 
GIL, Juca. Planos Educacionais: entre a prioridade e a descrença. In: SOUZA, Ângelo Ricardo (org.); GOUVEIA, Andréa Barbosa (org.); TAVARES, Taís Moura (Org.). Políticas Educacionais: conceitos e debates. $3^{\text {a }}$ ed. Curitiba: Appris, p. 121-146, 2016.

GOIS, Antônio. Verba do PAC da Educação demora a sair. Folha de São Paulo. São Paulo, 19 mai. 2008, p. C6. Disponível em:

<https://www1.folha.uol.com.br/fsp/cotidian/ff1905200817.htm>. Acesso em: 15 set. 2018.

GOLDSMITH, Stephen; EGGERS, Willian D. Governar em rede: o novo formato do setor público. Brasília / São Paulo: ENAP / UNESP, 2006.

GOMES, Candido Alberto et al. O financiamento da educação brasileira: uma revisão da literatura. Revista Brasileira de Política e Administração da Educação - ANPAE, v. 23, n. 1, 2007.

GOMES, Gustavo Maia; MAC DOWELL, Maria Cristina. Descentralização política, federalismo fiscal e criação de municípios: o que é mau para o econômico nem sempre é bom para o social. Texto para discussão IPEA n. 706, p. 1-29, 2000.

GONZÁLEZ, Felipe. À procura de respostas. Tradução João Gobern. Lisboa: Matéria Prima Edições, 2014.

GORDILLO, Augustín. Tratado de Derecho Administrativo. $10^{\mathrm{a}}$ ed. Buenos Aires: Fundación de Derecho Administrativo, 2011. Disponível em: 〈http://www.gordillo.com〉. Acesso em: 06 set. 2018.

GOUVEIA, Andréa Barbosa. O financiamento da educação no Brasil e o desafio da superação das desigualdades. In: SOUZA, Ângelo Ricardo (org.); GOUVEIA, Andréa Barbosa (org.); TAVARES, Taís Moura (Org.). Políticas Educacionais: conceitos e debates. $3^{\mathrm{a}}$ ed. Curitiba: Appris, p. 83-105, 2016.

GRATIOT-ALPHANDÉRY, H. Henri Wallon (1879-1962). Perspectives:revue trimestrielle d'éducation comparée, v. 24, n. 3, p. 821-835, 1994.

GRAU, Eros Roberto. A ordem econômica na Constituição de 1988 (interpretação e crítica). São Paulo: Revista dos Tribunais, 1990.

Planejamento econômico e regra jurídica. São Paulo: s.d.e., 1977.

GRIN, Eduardo José Grin; ABRUCIO, Fernando Luiz. Facetas del federalismo en Brasil: descentralización, recentralización y los desafíos de la cooperación intergubernamental. Revista Iberoamericana de Gobierno Local, Granada, n. 11, nov. 2016. Disponível em: <https://www.researchgate.net/publication/311456452>. Acesso em: 20 out. 2018.

GRIN, Eduardo José. Trajetória e avaliação dos programas federais brasileiros voltados a promover a eficiência administrativa e fiscal dos municípios. Revista de Administração Pública-RAP v. 48, n. 2, p. 459-480, 2014. 
GRIN, Eduardo José; ABRUCIO, Fernando Luiz. Inovação no associativismo territorial no Brasil: os Arranjos de Desenvolvimento da Educação. REDES: Revista do Desenvolvimento Regional, v. 22, n. 3, p. 39-64, 2017.

GUIMARÃES, Ulysses. Discurso por ocasião da promulgação da Constituição de 1988. Brasília, 1988. Disponível em: <http://www2.camara.leg.br/atividadelegislativa/plenario/discursos/escrevendohistoria/25-anos-da-constituicao-de-1988/ constituinte-1987-1988/pdf/Ulysses\%20Guimaraes\%20-\%20DISCURSO\%20\%20 REVISADO.pdf>. Acesso em: 08 jan. 2019.

HAMILTON, Alexander; MADISON, James; JAY, John. Selected federalist papers. New York: Dover Publications, 2001.

HANUSHEK, Eric A; RAYMOND, Margaret E. Does school accountability lead to improved student performance? Journal of policy analysis and management v. 24, n. 2, p. 297-327, 2005.

HANUSHEK, Eric. The Value of Teachers in Teaching. Santa Monica: Rand Corporation, 1970. Disponível em: < https://files.eric.ed.gov/fulltext/ED073089.pdf>. Acesso em: 23 nov. 2018.

HEIDEMANN, Francisco G.; SALM, José Francisco (orgs.). Políticas públicas e desenvolvimento: bases epistemológicas e modelos de análise. $3^{\mathrm{a}}$ ed. Brasília: Editora UnB, 2014.

HESSE, Konrad. Temas fundamentais do direito constitucional. Tradução Gilmar Mendes Ferreira; Inocência Mártires Coelho; Carlos dos Santos Almeida. São Paulo: Saraiva, 2009.

HORTA, José Silvério Baía. A Educação no Congresso Constituinte de 1966-67. Fávero, Osvaldo (org.). A Educação nas constituintes brasileiras. Campinas: Autores Associados, 2014. p. 169-210.

HOWLETT, Michael; RAMESH, Mishra; PERL, Anthony. Política pública: seus ciclos e subsistemas - uma abordagem integral. Tradução Francisco G. Heidemann. Rio de Janeiro: Elsevier, 2013.

IBGE. Instituto Brasileiro de Geografia e Estatística. Perfil dos Municípios Brasileiros 2006. Brasília, IBGE, 2006. Disponível em: <https://biblioteca.ibge.gov.br/visualizacao/livros/liv41211.pdf>. Acesso em: 23 jul. 2018.

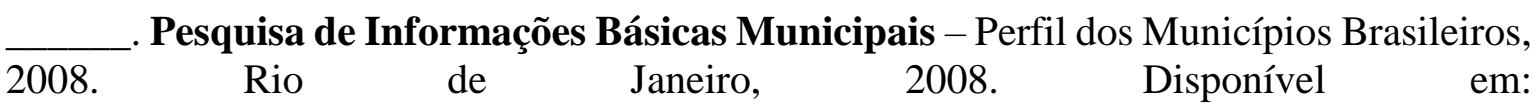
<https://biblioteca.ibge.gov.br/visualizacao/livros/liv41211.pdf>. Acesso em: 23 jul. 2018.

Perfil dos municípios brasileiros: 2011. Rio de Janeiro: IBGE, 2012. Disponível em: < https://ww2.ibge.gov.br/home/estatistica/economia/perfilmunic/2011/>. Acesso em: 1 nov. 2018. 
Perfil dos municípios brasileiros: 2015. Rio de Janeiro: IBGE, 2016. Disponível em: https://ww2.ibge.gov.br/home/estatistica/pesquisas/pesquisa_resultados.php?id_pesquisa= 89>. Acesso em: 08 nov. 2018.

Estatísticas de finanças públicas e conta intermediária de governo: Brasil:
2016. Rio de Janeiro: IBGE, 2018. Disponível em: < https://biblioteca.ibge.gov.br/index.php/bibliotecacatalogo?view=detalhes\&id=210157>. Acesso em: 13 out. 2018.

. Séries Históricas e Estatísticas. Rendimento médio mensal das pessoas de 10 anos ou mais de idade (R\$). Disponível em: $<$ https://seriesestatisticas.ibge.gov.br/series.aspx?no=7\&op=0\&vcodigo=PD345\&t=rendim ento-medio-mensal-pessoas-10-anos>. Acesso em: 16 set. 2018.

Sistema Nacional de Índices de Preços ao Consumidor. Séries Históricas. Disponível em: Os dados relativos ao IPCA-IBGE foram obtidos em: <https://ww2.ibge.gov.br/home/estatistica/indicadores/precos/inpc_ipca/defaultseriesHist.s htm>. Acesso em: 10 ago. 2018.

IMMERGUT, Ellen M. As regras do jogo: a lógica da política de saúde na França, na Suíça e na Suécia. Revista Brasileira de Ciências Sociais, v. 30, n. 11, p. 139-163, 1996.

. O núcleo teórico do novo institucionalismo. In: SARAVIA, Enrique; FERRAREZI, Elisabete (Orgs.). Políticas públicas. Coletânea - Volume 1. Brasília: ENAP, 2007.

INEP. Instituto Nacional de Estudos e Pesquisas Educacionais Anísio Teixeira. Sinopses estatísticas da Educação Básica - 1995. Brasília: INEP, 1995. Disponível em: <http://portal.inep.gov.br/sinopses-estatisticas-da-educacao-basica>. Acesso em 21 jun. 2018

. Plano Nacional de Educação. Brasília: INEP, 1998.

2000.

Educação para todos: a avaliação da década. Brasília: MEC/INEP p. 39-52,

Sinopses estatísticas da Educação Básica - 2002. Brasília: INEP, 2002. Disponível em: <http://portal.inep.gov.br/sinopses-estatisticas-da-educacao-basica> Acesso em 21 jun. 2018

Sinopses estatísticas da Educação Básica - 2014. Brasília: INEP, 2014. Disponível em: <http://portal.inep.gov.br/sinopses-estatisticas-da-educacao-basica>. Acesso em 29 set. 2018.

- Sinopses Estatísticas da Educação Básica, 2015a. Disponível em: <http://inep.gov.br/sinopses-estatisticas-da-educacao-basica〉. Acesso em: 05 nov. 2017.

2015b.

. Plano Nacional de Educação PNE 2014-2024 : Linha de Base. Brasília: INEP, 
Relatório do $1^{0}$ ciclo de monitoramento das metas do PNE : biênio 2014-2016. Brasília: INEP, 2016a.

Sinopses estatísticas da Educação Básica - 2016. Brasília: INEP, 2016b. Disponível em: <http://portal.inep.gov.br/sinopses-estatisticas-da-educacao-basica> Acesso em 29 set. 2018.

Brasil no PISA 2015: análises e reflexões sobre o desempenho dos estudantes brasileiros / OCDE-Organização para a Cooperação e Desenvolvimento Econômico. — São Paulo: Fundação Santillana, 2016c. Disponível em: $<$ http://download.inep.gov.br/acoes_internacionais/pisa/resultados /2015/pisa2015_completo_final_baixa.pdf>. Acesso em 23 nov. 2018.

Sinopses estatísticas da Educação Básica - 2017. Brasília: INEP, 2017. Disponível em: <http://portal.inep.gov.br/sinopses-estatisticas-da-educacao-basica>. Acesso em 29 set. 2018.

. Relatório do $2^{\circ}$ ciclo de monitoramento das metas do PNE : biênio 2014-2016. Brasília: INEP, 2018.

. Prova Docente. Disponível em: <http://portal.inep.gov.br/prova-docente>. Acesso em: 15 out. 2018.

JACOMINI, Márcia; ALVES, Thiago; CAMARGO, Rubens Barbosa de. Remuneração docente: desafios para o monitoramento da valorização dos professores brasileiros no contexto da meta 17 do Plano Nacional de Educação. Education Policy Analysis Archives/Archivos Analíticos de Políticas Educativas, v. 24, 2016.

JORGE, Ighor Rafael. A dimensão normativa das políticas públicas: a política de formação de professores no brasil. Dissertação de Mestrado apresentado ao Programa de Pós-Graduação da Faculdade de Direito da Universidade de São Paulo, 2018.

JUSTEN FILHO, Marçal. Curso de direito administrativo. $12^{\mathrm{a}}$ ed. rev. atual. ampl. São Paulo: RT, 2016. [ $4^{\mathrm{a}}$ ed. em e-book, 13,2 Mb, PDF].

KINGDON, John W. Agendas, Alternatives, and Public Policies. Boston: Little, Brown, 1984.

LEIVA LAVALLE, Jorge. Instituciones e instrumentos para el planeamiento gubernamental en América Latina. In: CARDOSO JR., José Celso (org). A reinvenção do planejamento governamental no Brasil. Brasília: IPEA, 2011 (Série: Diálogos para o Desenvolvimento, v. 4).

LEMME, Paschoal. Memórias de um educador. $2^{\mathrm{a}}$ ed. Brasília: Instituto Nacional de Estudos e Pesquisas Educacionais, 2004. 4 v.

LESSARD, Claude; CARPENTIER, Anylène. Políticas educativas: a aplicação na prática. Tradução Stephania Matousek. Petrópolis, RJ: Vozes, 2016.

LIBÂNEO, José Carlos. Adeus professor, adeus professora? Cortez Editora, 1998. 
LIMA, Ubirajara Couto; NEVES, Tiago Guedes Barbosa do Nascimento. Regime de colaboração: duas experiências de organização cooperativa na área de educação. Educação (UFSM), v. 43, n. 3, p. 553-564, 2018.

LINDBLOM, Charles E. Still Muddling, Not Yet Through. Public Administration Review, vol. 39, nº. 6, p. 517-526, nov.-dez. 1979.

2, p. 79-88, 1959.

. The science of "Muddling Through". Public Administration Review, vol. 19, no.

The intelligence of democracy: Decision making through mutual adjustment. New York: Free Press, 1965.

LIPSKY, Michael. Toward a theory of street-level bureaucracy. Institute for Research on Poverty, University of Wisconsin, 1969.

LOMBARDINI, Siro. Política econômica. In: BOBBIO, Norberto; MATTEUCCI, Nicola; PASQUINO, Gianfranco. Dicionário de política, $11^{\mathrm{a}}$ ed. Tradução de João Ferreira et al. Brasília: UNB, 1998.

LOURENÇO FILHO, Manoel Bergström. A formação de professores: da Escola Normal à Escola de Educação. $2^{a}$ ed. Brasília: Instituto Nacional de Estudos e Pesquisas Educacionais Anísio Teixeira, 2001.

A pedagogia de Rui Barbosa. Brasília: Instituto Nacional de Estudos e Pesquisas Educacionais Anísio Teixeira, 2001b.

Tendências da educação brasileira. 2. ed. Brasília: Instituto Nacional de Estudos

e Pesquisas Educacionais Anísio Teixeira, 2002.

LOUZANO, Paula; ROCHA, Valéria; MORICONI, Gabriela Miranda; OLIVEIRA, Romualdo Portela de. Quem quer ser professor? Atratividade, seleção e formação do docente no Brasil. Estudos em avaliação educacional, v. 21, n. 47, p. 543-568, 2010.

MACHADO, Maria Aglaê de Medeiros. O Plano Decenal e os Compromissos de Jomtien : da palavra a ação. In: MINISTÉRIO DA EDUCAÇÃO E CULTURA; INSTITUTO NACIONAL DE ESTUDOS E PESQUISAS EDUCACIONAIS ANÍSIO TEIXEIRA INEP. Educação para todos: a avaliação da década. Brasília: MEC/INEP p. 39-52, 2000.

Rui Barbosa. Recife: Fundação Joaquim Nabuco, Editora Massangana, 2010. (Coleção Educadores - MEC).

MADEIRA, Ricardo. INSTITUTO UNIBANCO (org.) Caminhos para a qualidade da educação públic: impactos e evidências. São Paulo: Fundação Santillana, 2017.

MAGALHÃES, João Carlos. Emancipação político-administrativa de municípios no Brasil. Dinâmica dos municípios. Brasília: IPEA, p. 13-21, 2007.

MAIA, Maurício Holanda. Regime de colaboração no PNE: antecedentes, propostas, perspectivas e desafios. In: GOMES, Ana Valeska Amaral et al. Plano Nacional de 
Educação: olhares sobre o andamento das metas. Brasília: Câmara dos Deputados, p. 305332, 2017.

MARQUES NETO, Floriano de Azevedo. Parecer PL 11107 08/03/2005. Revista Jurídica da Presidência, v. 7, n. 72, 2005. Disponível em: <https://revistajuridica. presidencia.gov.br/index.php/saj/article/download/526/519>. Acesso em: 18 nov. 2018.

MARQUES, Eduardo. Path dependence. In: DI GIOVANNI, Geraldo; NOGUEIRA, Marco Aurélio (orgs). Dicionário de políticas públicas. $2^{\text {a }}$ ed. São Paulo: FUNDAP; Editora UNESP, 2015.

MARRAFON, Marco Aurélio. Federalismo brasileiro: reflexões em torno da dinâmica entre autonomia e centralização. In: CLÉVE, Clemerson Merlin. Direito Constitucional Brasileiro. São Paulo: Revista dos Tribunais, v. II, p. 95-121, 2014.

MARRARA, Thiago. A atividade de planejamento na Administração Pública: o papel e o conteúdo das normas previstas no anteprojeto da Nova Lei de Organização Administrativa. Revista Brasileira de Direito Público - RBDP, Belo Horizonte, ano 9, n. 34, jul./set. 2011. Disponível em: <http://www.bidforum.com.br/PDI0006.aspx?pdiCntd=74850>. Acesso em: 3 set. 2018.

MARTINELLI, Nereide Lúcia; VIANA, Ana Luiza d'Ávila; SCATENA, João Henrique Gurtler. O Pacto pela Saúde e o processo de regionalização no estado de Mato Grosso. Saúde em Debate, v. 39, n. spe, p. 76-90, 2015.

MARTINS, Angela Maria. Uma análise da municipalização do ensino no Estado de São Paulo. Cadernos de Pesquisa n. 120, p. 221-238 , 2003.

MARTINS, Paulo de Sena. Carta de Goiânia. Cadernos Aslegis, n. 54, p. 141-8, 2018.

2011.

. FUNDEB, federalismo e regime de colaboração. Campinas: Autores Associados,

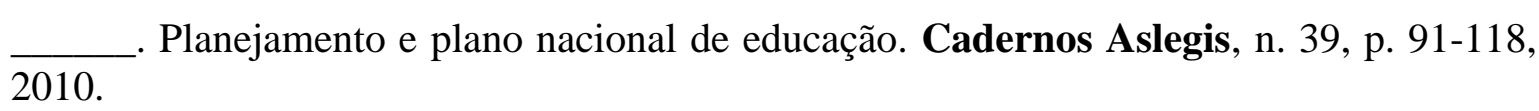

MARTINS, Wilson. História da inteligência brasileira. São Paulo: Cultrix, EDUSP, 1977. vol. II.

MATUS, Carlos. Teoria do jogo social. Tradução Luis Felipe Rodriguez Del Riego; revisão técnica Vanya Mundim Sant'Anna. São Paulo: FUNDAP, 2005.

MAURER, Hartmut. Direito administrativo geral. Tradução Luis Afonso Heck. Barueri: Manole, 2006.

MCGUIRE, Michael. Collaborative public management: Assessing what we know and how we know it. Public administration review, v. 66, p. 33-43, 2006.

MEDAUAR, Odete. A processualidade no direito administrativo. São Paulo: Revista dos Tribunais, 1993. 
MELCHIOR, José Carlos de Araújo. Financiamento da educação no Brasil numa perspectiva democrática. Cadernos de Pesquisa n. 34, p. 39-83, 1980.

MELLO, Celso Antonio Bandeira. Curso de Direito Administrativo. $27^{\mathrm{a}}$ ed. rev. atual. São Paulo: Malheiros, 2010.

MELLO, Evaldo Cabral. O nome e o sangue: uma fraude genealógica no Pernambuco Colonial. São Paulo, Companhia das Letras, 1989.

MENDES, Gilmar Ferreira; BRANCO, Paulo Gustavo Gonet. Curso de direito constitucional. $8^{\text {a }}$ ed. rev. atual. São Paulo: Saraiva, 2013.

MENDES, Marcos. Descentralização do ensino fundamental: avaliação de resultados do FUNDEF. Planejamento e Políticas Públicas, Brasília, nº 24, p. 27-51, dez. 2001.

MENDLOVITZ, Marcos. Análise dos efeitos da PEC n⿳ 241 sobre a Manutenção e Desenvolvimento do Ensino. Câmara dos Deputados; Consultoria de Orçamento e Fiscalização Financeira. Estudo Técnico $\mathrm{n}^{\mathrm{o}}$ 11, 2016 (revisado). Disponível em: $<$ http://www2.camara.leg.br/atividade-legislativa/orcamentobrasil/estudos/2016/et112016-analise-dos-efeitos-da-pec-no-241-sobre-a-manutencao-e-desenvolvimento-doensino>. Acesso em: 21 out. 2018.

MINHOTO, Maria Angélica Pedra. Política de avaliação da educação brasileira: limites e perspectivas. In: SOUZA, Ângelo Ricardo (org.); GOUVEIA, Andréa Barbosa (org.); TAVARES, Taís Moura (org.). Políticas Educacionais: conceitos e debates. $3^{\mathrm{a}}$ ed. Curitiba: Appris, 2016.

MINISTÉRIO DA EDUCAÇÃO. MEC. Plano Nacional de Alfabetização e Cidadania: marcos de referência. Brasília, MEC, 1991. Disponível em: $\langle$ http://www.dominiopublico.gov.br/download/texto/me000684.pdf $>$. Acesso em 04 ago. 2018 .

Plano decenal de educação para todos. Brasília: MEC, 1993 - versão atualizada. Disponível em: <http://www.dominiopublico.gov.br/ download/texto/me001523.pdf>. Acesso: 7 set. 2018.

Plano decenal de educação para todos. Brasília: MEC, 1993 - versão atualizada. Disponível em: <http://www.dominiopublico.gov.br/ download/texto/me001523.pdf>. Acesso: 7 set. 2018.

Conferência Nacional de Educação: documento final. Brasília: MEC, 2010. Disponível em: <http://pne.mec.gov.br/images/pdf/CONAE2010_doc_final.pdf>. Acesso: 23 set. 2018.

Relatório de cumprimento do Piso Salarial dos municípios e entes federativos. Brasília, $2016 . \quad$ Disponível em: <http://planodecarreira.mec.gov.br/images/pdf/relatorio_pspn.pdf>. Acesso em: 10 ago. 2018. 
- SASE divulga relatório do cumprimento do Piso Salarial Profissional do magistério público. Brasília, 17 jan. 2017. Disponível em: $<$ http://planodecarreira.mec.gov.br/destaques/66-sase-divulga-relatorio-do-cumprimentodo-piso-salarial-profissional-do-magisterio-publico>. Acesso em: 10 ago. 2018.

. O Plano de Desenvolvimento da Educação - Razões, Princípios e Programas. Brasília. Disponível em: <http://portal.mec.gov.br/arquivos/livro/livro.pdf〉. Acesso em: 15 set. 2018.

Rede de Assistência. Disponível em: <http://planodecarreira.mec.gov.br/rede-deassistencia> . Acesso em: 14 out. 2018.

. Tabela de Evolução PSPN. Disponível em: <http://planodecarreira.mec.gov.br/ images/pdf/tabela_evolucao_pspn.pdf $>$. Acesso em: 10 ago. 2018.O Plano de Desenvolvimento da Educação - Razões, Princípios e Programas. Brasília. Disponível em: <http://portal.mec.gov.br/arquivos/livro/livro.pdf>. Acesso em: 15 set. 2018.

. Rede de Assistência. Disponível em: <http://planodecarreira.mec.gov.br/rede-deassistencia> . Acesso em: 14 out. 2018.

. Tabela de Evolução PSPN. Disponível em: <http://planodecarreira.mec.gov.br/ images/pdf/tabela_evolucao_pspn.pdf >. Acesso em: 10 ago. 2018.

MINISTÉRIO DA EDUCAÇÃO E CULTURA; INSTITUTO NACIONAL DE ESTUDOS E PESQUISAS EDUCACIONAIS ANÍSIO TEIXEIRA - INEP. Educação para todos: a avaliação da década. Brasília: MEC/INEP, 2000.

MINTO, Lalo Watanabe. Capital Humano. In: Grupo de Estudos e Pesquisas "História, Sociedade e Educação no Brasil". Navegando na História da Educação Brasileira. da Faculdade de Educação da Unicamp, Campinas, 2006. Disponível em: http://www.histedbr.fe.unicamp.br/navegando/glossario/verb_c_teoria_\%20do_capital_hu mano.htm>. Acesso em 18 nov. 2018.

MOBILIZADORES do "FUNDEB pra Valer" são recebidos em Brasília. Folha de São Paulo, $1^{\circ}$ set. 1995. Disponível em: <https://www1.folha.uol.com.br/folha/dimenstein/ noticias/gd010905.htm>. Acesso em: 23 jul. 2018.

MONLEVADE, João Antonio Cabral de. Valorização salarial dos professores: o papel do piso salarial profissional nacional como instrumento de valorização dos professores da educação básica pública. Tese de Doutorado, Campinas: Universidade Estadual de Campinas - UNICAMP, 2000.

Meta 18 do PNE: para entendê-la e colocá-la em prática. In: GOMES, Ana Valeska Amaral et al. Plano Nacional de Educação: olhares sobre o andamento das metas. Brasília: Câmara dos Deputados, p. 249-273, 2017.

MORAIS, Christianni Cardoso; OLIVEIRA, Cleide Cristina. Aulas régias, cobrança do subsídio literário e pagamento dos ordenados dos professores em Minas Gerais no período colonial. Revista Educação em Perspectiva v. 3, n. 1, 2012. 
MORAND, Charles-Albert. Le droit neo moderne des politiques publiques. Paris: LGDJ, 1999.

MORENO, Ana Carolina. Justiça derruba decisão que obrigava MEC a implementar valor de gasto por aluno. G1. Educação. Disponível em: $<$ https://g1.globo.com/educacao/noticia/justica-derruba-decisao-que-obrigava-mec-aimplementar-valor-de-gasto-por-aluno.ghtml>. Acesso em: 24 jul. 2018.

NAGLE, Jorge. Educação e sociedade na Primeira República. $3^{\text {a }}$ ed. São Paulo: EDUSP, 2009.

NEGRI, Barjas. O Financiamento Público da Educação Básica no Brasil: 1988-2012. In: NEGRI, Barjas (org.); TORRES, Haroldo da Gama (org.); CASTRO, Maria Helena Guimarães (org.); GOUVEA, Gilda Figueiredo Portugal (coord. técnica do projeto). Educação básica no Estado de São Paulo: avanços e desafios. São Paulo: Fundação SEADE/FDE, p. 37-82, 2014.

NEUBAUER, Rose. Reorganização das escolas estaduais paulistas: um novo modelo pedagógico e a municipalização. São Paulo: Fundação SEADE, 26 jul. 2014. 46 slides. Disponível em: <http://www.seade.gov.br/wpcontent/uploads/2014/06/Reorganiza\%C3\%A7\%C3\%A3o-das-escolas.pdf > . Acesso em: 18 jun. 2018.

NEVES, Marcelo. Constitucionalização simbólica e desconstitucionalização fática: mudança simbólica da constituição e permanência das estruturas reais de poder. Revista de Informação Legislativa, Brasília, a. 33, n. 132, p. 321-330, out./dez. 1996.

NICOLETI, João Ernesto. Arranjos de desenvolvimento da educação: uma alternativa partilhada de gestão municipal da educação. Tese (Doutorado em Educação) apresentada ao Programa de Pós-Graduação em Educação Escolar da Faculdade de Ciências e Letras da Universidade Estadual Paulista "Júlio de Mesquita Filho"- Unesp, AraraquaraVitória, 2014. Disponível em: < https://repositorio.unesp.br/handle/11449/122046 >. Acesso em: 09 nov. 2018.

NOHARA, Irene Patrícia. Direito administrativo. $4^{\circ}$ ed. São Paulo: Atlas, 2014.

O OBSERVATÓRIO. Todos pela Educação. Disponível em: <http://www.observatoriodopne.org.br/> . Acesso em: 24 de setembro de 2018.

O PISO SALARIAL DOS PROFESSORES. O Estado de São Paulo. São Paulo, 3 ago. 2008. Editorial, 8 de agosto de 2008, p. A3. Disponível em: <https://acervo.estadao.com.br/pagina/\#!/20080808-41933-spo-3-edi-a3not/busca/lei+piso+magist\%C3\%A9 rio>. Acesso em 06 ago 2018.

O PLANO e os mestres. Folha de São Paulo, São Paulo, 26 abr. de 2007, p. A2. Disponível em: <https://acervo.folha.com.br/>. Acesso em: 16 set. 2018.

O'LEARY, Rosemary; VIJ, Nidhi. Collaborative public management: Where have we been and where are we going?. The American Review of Public Administration, v. 42, n. 5, p. 507-522, 2012. 
OECD. Organization for Economic Co-operation and Development. Teachers matter: education and training policy - attracting, developing and retaining effective teachers. Paris: OECD Publishing, 2005. 240 p. Disponível em: <https://www.oecd.org/edu/school/34990905.pdf>. Acesso em: 22 nov. 2018.

Política de educación y formación: Los docentes son importantes: Atraer, formar y conservar a los docentes eficientes. Paris: OECD Publishing, 2009.

Que fatores determinam os gastos com o corpo docente? Indicadores Educacionais em Foco, n. 12, março, 2013. Disponível em: <http://download.inep.gov.br/acoes_internacionais/ estatisticas_educacionais/indicadores_educacionais_foco/indicadores_educacionais_foco_ n_12.pdf>. Acesso em: 03 nov. 2018.

PISA 2015. Country Note: Brazil. Paris: OECD Publishing, 2015. Disponível em: <http://www.oecd.org/pisa/pisa-2015-Brazil.pdf〉. Acesso em: 24 nov. 2018.

. Education at a glance 2018. Country Note: Brazil. Paris: OECD Publishing, 2018. Disponível em: <http://gpseducation.oecd.org/Content/EAGCountryNotes/BRA.pdf>. Acesso em: 22 nov. 2018a.

Effective teacher policies: insights from PISA. Paris: OECD Publishing, 2018b Disponível em: < http://www.oecd.org/education/effective-teacher-policies9789264301603-en.htm>. Acesso em: 24 nov. 2018b.

"Brazil", in Education at a Glance 2017: OECD Indicators. Paris: OECD Publishing, 2018. Disponível em: <http://gpseducation.oecd.org/Content/ EAGCountryNotes/BRA.pdf>. Acesso em: 2 nov. 2018.

OLIVEIRA, Alison Pablo; FRANCO, Ana Maria de Paiva; MENEZES FILHO, Naercio. Impactos do FUNDEF sobre matrículas, docentes e escolas em São Paulo. In: NEGRI, Barjas (org.); TORRES, Haroldo da Gama (org.); CASTRO, Maria Helena Guimarães (org.); GOUVEA, Gilda Figueiredo Portugal (coord. técnica do projeto). Educação básica no Estado de São Paulo: avanços e desafios. São Paulo: Fundação SEADE/FDE, p. 37-82,

OLIVEIRA, José Antônio Puppim de. Desafios do planejamento em políticas públicas: diferentes visões e práticas. Revista de Administração Pública-RAP, Rio de Janeiro, v. 40, n. 2, p. 273-88, 2006.

OLIVEIRA, Romualdo Portela De. Educação na Assembleia Constituinte de 1946. Fávero, Osvaldo (org.). A Educação nas constituintes brasileiras. Campinas: Autores Associados, p. 169-210, 2014.

OLIVEIRA, Vitor; MENEZES-FILHO, Naercio; KOMATSU, Bruno. A relação entre a qualidade da gestão municipal e o desempenho educacional no Brasil. Insper - Centro de Políticas Públicas. Policy paper nº 34, ago. 2018.

PALMA FILHO, João Cardoso. A República e a Educação no Brasil: Primeira República (1889-1930). Acervo Digital Univesp p. 1-14, 2005. 
PARO, V. H. Eleição de diretores de escolas públicas: avanços e limites da prática. Revista Brasileira de Estudos Pedagógicos. Brasília, v.77, n.186, p. 376-395, maio/ago. 1996. Disponível em: <http://rbep.inep.gov.br/index.php/RBEP/rticle/ viewFile/289/291>. Acesso em: 20 out. 2018.

PEREIRA, Luís. O professor primário metropolitano. Rio de Janeiro: Centro Brasileiro de Pesquisas Educacionais, Instituto Nacional de Estudos Pedagógicos, Ministério da Educação e Cultura, 1963. 3 v. (Coleção O Brasil Urbano).

PEREIRA, Luiz Carlos Bresser. Da administração pública burocrática à gerencial. Revista do Serviço público v. 47, n. 1, p. 7-40, 1996.

PÉREZ GÓMEZ, A. I. A cultura escolar na sociedade neoliberal. Tradução Ernani Rosa. Porto Alegre: Artmed, 2001.

PEREZ, Marcos Augusto. A administração pública democrática. $1^{\text {a }}$ ed., $1^{\text {a }}$ reimpr. Belo Horizonte: Fórum, 2009.

PETERS, B. Guy. La política de la burocracia. Tradução Eduardo L. Suárez Galindo. México: Fondo de Cultura Económica, 1999.

PILETTI, Claudino; PILETTI, Nelson. História da educação: de Confúcio a Paulo Freire. São Paulo: Editora Contexto, 2012.

PINHEIRO, Maria Francisca. O público e o privado na educação: um conflito fora de moda? In: FÁVERO, Osmar (Org.). A educação nas constituintes brasileiras. Campinas: Atores Associados, 2014.

PINO, Ivany. A Lei de Diretrizes e Bases da Educação: a ruptura do espaço social e a organização da educação nacional. BRZEZINSKI, Iria (org). LDB/1996: uma década de perspectivas e perplexidades na formação de profissionais da educação. LDB dez anos depois: reinterpretações sob diversos olhares. São Paulo: Cortez, p. 17-41, 2008.

PINTO, Angela. AGU analisará mudanças na lei do piso do professor. Folha de São Paulo. São Paulo, 15 de ago. de 2008. p. C7. Disponível em: $<$ https://acervo.folha.com.br/leitor.do?numero=17630\&keyword=professor\%2Cpiso $\% 2 \mathrm{C}$ lei\&anchor $=5318184 \&$ origem $=$ busca\&pd=bbb21df9a538fd09948db12d77be20b3 > . Acesso em: 06 ago. 2018.

PINTO, José Marcelino de Rezende. Federalismo, descentralização e planejamento da educação: desafios aos municípios. Cadernos de Pesquisa, São Paulo, v. 44, n. 153, p. 624$644,2014$.

. Uma proposta de custo-aluno-qualidade na educação básica. Revista Brasileira de Política e Administração da Educação, Goiânia, v. 22, n. 02 , 2006.

Financiamento da Educação no Brasil: um balanço do governo FHC. Educação e Sociedade, Campinas, v. 23, n. 80, p. 108-135, 2002. 
PRADO, Mariana Mota. Institutional Bypass: An Alternative for Development Reform. SSRN, abr. 2011. Disponível em: 〈https://ssrn.com/abstract=1815442〉. Acesso em: 05 nov. 2018.

PRADO, Mariana Mota; CHASIN, Ana Carolina Da Matta. How innovative was the Poupatempo experience in Brazil? Institutional bypass as a new form of institutional change. Brazilian political Science review, v. 5, n. 1, p. 11-34, 2011.

PRADO, Mariana Mota; TREBILCOCK, Michael. Path Dependence, Development, and the Dynamics of Institutional Reform. University of Toronto Law Journal, Toronto, v. 59, n. 3, p. 341-379, 2009.

PRESSMAN, Jeffrey L.; WILDAVSKY, Aaron. Implementation: How Great Expectations in Washington Are Dashed in Oakland; Or, Why It's Amazing that Federal Programs Work at All, This Being a Saga... Morals on a Foundation (Oakland Project). University of California Press, 1973.

PRITCHETT, Lant. Where has all the education gone? The world bank economic review, v. 15, n. 3, p. 367-391, 2001.

PROCOPIUCK, Mario. Políticas públicas e fundamentos da administração pública: análise e avaliação, governança e redes de políticas, administração judiciária. São Paulo: Atlas, 2013.

PROJETO tem mais de mil emendas e enfrenta 'percurso' antes da votação. Folha de São Paulo. São Paulo, , 22 de jul.ho de 1991, Caderno Cotidiano, p. 4-2. Disponível em: <https://acervo.folha.com.br/>. Acesso em: 6 mai. 2018.

RAMINELLI, Ronald. Justificando nobrezas: velhas e novas elites coloniais - 1750-1807. História (São Paulo) v. 35, n. 97, p. 1-26, 2016.

RANIERI, Nina. Educação superior, direito e estado: na Lei de diretrizes e bases, Lei. São Paulo: EDUSP/FAPESP, 2000.

REALE JR., Miguel. O papel da sociedade civil da ditadura ao neopopulismo. In: MOTA, Carlos Guilherme; SALINAS, Natasha S. C. (Orgs.). Os juristas na formação do Estado Nação brasileiro: 1930-dias atuais. São Paulo: Saraiva, 2010. p. 535-552.

RECEITA FEDERAL. Carga Tributária no Brasil - 2016. Brasília: Ministério da Fazenda, Receita $2017 . \quad$ Dederal, em: <http://idg.receita.fazenda.gov.br/dados/receitadata/estudos-e-tributarios-e-aduaneiros/ estudos-e-estatisticas/carga-tributaria-no-brasil/carga-tributaria-2016.pdf >. Acesso em: 13 out. 2018.

RIBEIRO, Renato Janine. A Pátria Educadora em colapso: reflexões de um ex-ministro sobre a derrocada de Dilma Rousseff e o futuro da educação no Brasil. São Paulo: Três Estrelas, 2018. 
RIBEIRO, Renato Jorge Brown; BLIACHERIENE, Ana Carla. Construindo o planejamento público: buscando a integração entre política, gestão e participação popular. São Paulo: Atlas, 2013.

RIO, João do (Paulo Barreto). O momento literário. Rio de Janeiro: H. Garnier,1908. Transcrição digital disponível em: <https://digital.bbm.usp.br/handle/bbm/1977>. Acesso em: 29 set. 2018.

ROCHA, Gessyca. Plano Nacional de Educação tem uma meta alcançada em 20 e risco de estagnação e descumprimento, diz relatório. G1, 7 jun. 2018. Disponível em: $<$ https://g1.globo.com/ educacao/noticia/plano-nacional-de-educacao-tem-uma-metaalcancada-em-20-e-risco-de-estagnacao-e-descumprimento-diz-relatorio.ghtml >. Acesso em: 29 set. 2018.

ROCHA, Maria da Consolação. Políticas de valorização do magistério: remuneração, plano de carreira, condições de trabalho: uma análise da

ROCHA, Marlos Bessa Mendes da. Tradição e modernidade na educação: o processo constituinte de 1933-34. In: FÁVERO, Osmar (Org.). A Educação nas constituintes brasileiras, 1823-1988. Campinas: Autores Associados, 2014.

RODRIGUEZ, Vicente et al. Financiamento da educação e políticas públicas: o FUNDEF e a política de descentralização. Cadernos Cedes, Campinas, ano XXI, nº 55, p. 42-57, novembro/200.

RODRIK, Dani. Goodbye Washington consensus, hello Washington confusion? A review of the World Bank's economic growth in the 1990s: learning from a decade of reform. Journal of Economic literature v. 44, n. 4, p. 973-987, 2006. Disponível em: $<$ https://aae.wisc.edu/coxhead/courses/731/pdf/rodrik\%20goodbye\%20washington $\% 20$ con sensus\%20jel\%202006.pdf> . Acesso em 01 mar. 2018.

ROMANO, Santi. O Ordenamento Jurídico. Tradução de Arno Dal Ri Jr. Florianópolis: Fundação Boiteux, 2008.

ROTHSTEIN, Bo. The quality of government: Corruption, social trust, and inequality in international perspective. Chigago/London: University of Chicago Press, 2011.

SABATIER, Paul A. Top-down and bottom-up approaches to implementation research: a critical analysis and suggested synthesis. Journal of public policy, v. 6, n. 1, p. 21-48, 1986.

SALDAÑA, Paulo. "Vélez indica para secretarias do MEC ex-alunos de filosofia sem experiência de gestão". Folha de São Paulo, São Paulo, 4 jan. 2019. Disponível em: <https://www1.folha.uol.com.br/educacao/ 2019/01/velez-indica-para-secretarias-do-mecex-alunos-de-filosofia-sem-experiencia-de-gestao.shtml>. Acesso em 4 jan. 2019.

SANDEL, Michael J. O Que O Dinheiro Não Compra. Rio de Janeiro: Editora José Olympio, 2012. 
SANT'ANNA, Vanya. Planejamento. In: DI GIOVANNI, Geraldo; NOGUEIRA, Marco Aurélio (orgs). Dicionário de políticas públicas. $2^{\mathrm{a}}$ ed. São Paulo: FUNDAP; Editora UNESP, p. 671-6, 2015.

SANTOS FERREIRA, Márcia. Os Centros de Pesquisas Educacionais do INEP e os estudos em ciências sociais sobre a educação no Brasil. Revista Brasileira de Educação v. 13, n. $38,2008$.

SANTOS, Fernanda Julyanna Silva dos; SAMPAIO, Raquel Menezes Bezerra; SAMPAIO, Luciano Menezes Bezerra. Eleição nas escolas: uma análise do impacto do diretor eleito sobre o desempenho educacional no Estado da Bahia. Pesquisa e planejamento econômico. Brasília, IPEA, v. 46, n. 1, abr. 2016. Disponível em: <http://repositorio.ipea.gov.br/handle/11058/6652>. Acesso em: 20 out. 2018.

SANTOS, Flávio Rosendo dos; OLIVEIRA, Antônio Gonçalves de; VICENTIN, Ivan Carlos. O planejamento na Administração Pública como decorrência do direito fundamental à boa administração. Fórum Administrativo - FA, Belo Horizonte, ano 16, n. 181, p. 2635, mar. 2016.

SANTOS, Manoel Leonardo; MANCUSO, Wagner Pralon; BAIRD, Marcello Fragano; RESENDE, Ciro Antônio da Silva. Lobbying no Brasil: profissionalização, estratégias e influência. Brasília: IPEA, 2017. (Série: Texto para discussão IPEA, n. 2334).

SÃO PAULO (Estado). Lei no 82 , de 01 de abril de 1889. Orça a receita e fixa a despesa das Câmaras Municipais. Secretaria do Governo da Provincia de São Paulo. 01 abri. 1889. Disponível em: < http://www.al.sp.gov.br/repositorio/legislacao/lei/1889/lei-8201.04.1889.html>. Acesso em: 28.05.2017.

Decreto $^{\circ}$ 5.884, de 21 de abril de 1933. Institue o Codigo de Educação do Estado de São Paulo. Diário do Executivo. São Paulo, 1933. p. 19 Disponível em: $<$ http://www.al.sp.gov.br/repositorio/legislacao/ decreto/1933/decreto-588421.04.1933.html>. Acesso em: 25 jun. 2017.

Decreto-lei $\mathrm{n}^{\mathrm{o}} 12.427$, de 23 de dezembro de 1941. Consubstancia novas disposições relativas à carreira do magistério público primário, e dá outras providências. Diário Oficial do Estado de São Paulo. São Paulo, 1941, p.1. Disponível em: <http://dobuscadireta.imprensaoficial.com.br/default.aspx? DataPublicacao $=19411224 \& \mathrm{Ca}$ derno=Diario\%20Oficial\&NumeroPagina=1>. Acesso em: 04 set. 2017.

Decreto-lei no 13.440 , de 30 de junho de 1943. Ratifica o Convênio Nacional de Ensino Primário. Diário Oficial do Estado de São Paulo. São Paulo, 1943. Disponível em: <http://www.al.sp.gov.br/repositorio/legislacao/decreto.lei/1943/decreto.lei-1344030.06.1943.html> . Acesso em: 04 set. 2017.

Lei $\mathrm{n}^{\circ}$ 10.261, de 28 de outubro de 1968. Dispõe sobre o Estatuto dos Funcionários Públicos Civis do Estado. Diário Oficial do Estado de São Paulo. São Paulo, 1968. p.2. Disponível em: <http://dobuscadireta.imprensaoficial.com.br/default.aspx? DataPublicacao $=19681029 \& \mathrm{Ca}$ derno=Poder\%20Executivo\&NumeroPagina=2> . Acesso em 19 jan. 2018. 
Lei $\mathrm{n}^{\circ}$ 435, de 24 de setembro de 1974. Autoriza o Poder Executivo a instituir Fundação, que se denominará "Fundação do Desenvolvimento Administrativo". Diário Oficial do Estado de São Paulo. São Paulo, 1974. p.3. Disponível em: <https://www.al.sp.gov.br/norma/?id=38739>. Acesso em: 04 set. 2017.

Lei Complementar $\mathrm{n}^{\mathrm{o}}$ 1.044, de 13 de maio de 2008. Institui o Plano de Carreiras, de Empregos Públicos e Sistema Retribuitório dos servidores do Centro Estadual de Educação Tecnológica "Paula Souza" - CEETEPS. Diário Oficial do

Estado de São Paulo. São Paulo, 2008. p.1. Disponível em: $<$ https://www.al.sp.gov.br/repositorio/legislacao/lei.complementar/2008/compilacaolei.complementar-1044-13.05.2008.html>. Acesso em: 05 out. 2018.

. Lei $n^{\circ} 16.019$, de 27 de novembro de 2015. Dispõe sobre a extinção da Fundação do Desenvolvimento Administrativo - FUNDAP e dá providências correlatas. Diário Oficial do Estado de São Paulo. São Paulo, 2015. p.1. Disponível em: <https://www.al.sp.gov.br/norma/176560>. Acesso em: 05 out. 2018.

Secretaria da Educação. Resolução SE 72, de 22.12.2016. Dispõe sobre o processo anual de atribuição de classes e aulas ao pessoal docente do Quadro do Magistério, referente a atribuição de aulas para o ano de 2017. Disponível em: <http://siau.edunet.sp.gov.br/ItemLise/arquivos/72_16.HTM? Time=09/09/2017 \%2007:51:40>. Acesso em 01 nov. 2017.

Tribunal de Justiça de São Paulo. Apelação 1012025-73.2017.8.26.0053. Relatora: Luciana Bresciani. Órgão Julgador: $2^{a}$ Câmara de Direito Público; Foro Central - Fazenda Pública/Acidentes - $7^{\mathrm{a}}$ Vara de Fazenda Pública; Data do Julgamento: 05/12/2017; Data de Registro: 06/12/2017. Disponível em: $<$ https://esaj.tjsp.jus.br/cjsg/getArquivo.do?cdAcordao $=11047032 \& c d F o r o=0>$. Acesso em: 11 ago. 2018

Tribunal de Justiça de São Paulo. Apelação 1012025-73.2017.8.26.0053. Relatora: Luciana Bresciani. Órgão Julgador: $2^{a}$ Câmara de Direito Público; Foro Central - Fazenda Pública/Acidentes - $7^{\mathrm{a}}$ Vara de Fazenda Pública; Data do Julgamento: 05/12/2017; Data de Registro: 06/12/2017. Disponível em: <https://esaj.tjsp.jus.br/cjsg/getArquivo.do?cdAcordao $=11047032 \&$ cdForo $=0>$. Acesso em: 11 ago. 2018

SARMENTO, Daniel. 21 Anos da Constituição de 1988: a Assembleia Constituinte de 1987/1988 e a Experiência Constitucional Brasileira sob a Carta de 1988. Direito Público, v. 6, n. 30, p. 7-41, nov./dez. 2009.

SAVIANI, Dermeval. A nova LDB. Pro-Posições. v. 1, n. 1, p. 7-13, 1997.

Educação: do senso comum à consciência filosófica. $11^{\mathrm{a}}$ ed. Campinas: Autores associados, 1996.

O manifesto dos pioneiros da educação nova de 1932 e a questão do sistema nacional de educação. In: CUNHA, Célio da; GADOTTI, Moacir; BORDIGNON, Genuíno; NOGUEIRA, Flávia Maria de Barros (orgs). O Sistema Nacional de Educação: diversos 
olhares 80 anos após o Manifesto. Brasília : Ministério da Educação; Secretaria de Articulação com os Sistemas de Ensino, 2014.

O Plano de Desenvolvimento da Educação: análise do projeto do MEC. Educação \& Sociedade, Campinas, vol. 28, n. 100 - Especial, p. 1231-1255, out. 2007.

Sistema Nacional de Educação articulado ao Plano Nacional de Educação. Revista Brasileira de Educação, v. 15, n. 44, p. 380-412, mai./ago. 2010.

SCHUELER, Alessandra Frota Martinez De; MAGALDI, Ana Maria Bandeira de Mello. Educação escolar na Primeira República: memória, história e perspectivas de pesquisa. Tempo. Revista do Departamento de História da Universidade Federal Fluminense v. 13, n. 26, p. 43-66, 2009.

SEARLE, John R. et al. The construction of social reality. London: Penguim, 1996.

SEARLE, John R. What is an institution? Journal of institutional economics, v. 1, n. 1, p. $1-22,2005$.

SECRETARIA DO TESOURO NACIONAL. STN. Aspectos fiscais da educação no Brasil. Brasília: STN, 2018. Disponível em: < http://www.tesouro.fazenda.gov.br/documents/10180/617267/CesefEducacao9jul18/4af4a6 db-8ec6-4cb5-8401-7c6f0abf6340>. Acesso em: 13 out. 2018.

SEGATTO, Catarina; ABRUCIO, Fernando. A gestão por resultados na educação em quatro estados brasileiros. Revista do Serviço Público, v. 68, n. 1, p. 85, 2017.

SENA, Paulo. A história do PNE e os desafios da nova lei. Plano Nacional de Educação 2014-2024. $2^{a}$ ed. Brasília : Câmara dos Deputados, Edições Câmara, 2015. Disponível em: <http://livraria.camara.leg.br/educacao/plano-nacional-de-educac-o-2014-2024.html>.

Acesso em: 21 set. 2018.

O Plano Nacional de Educação na Câmara dos Deputados: por um PNE já. Cadernos Aslegis. Brasília, n. 10, p. 64-72, 2000.

O Sistema Nacional de Educação (SNE) e o Custo Aluno-Qualidade (CAQ): as metas estruturantes para o cumprimento do PNE subiram no telhado? In: GOMES, Ana Valeska Amaral et al. Plano Nacional de Educação: olhares sobre o andamento das metas. Brasília: Câmara dos Deputados, p. 275-304, 2017.

SILVA, Almiro do Couto e. Problemas jurídicos do planejamento. Revista de Direito Administrativo, v. 170, p. 1-17, 1987.

SILVA, Diana de Cássia. Subsídio literário: um imposto para educar no "período das luzes". In: XXIII SIMPÓSIO NACIONAL DE HISTÓRIA, 2005, Londrina. Anais. Londrina: ANPUH - Asssociação Nacional de História, 2005.

SILVA, José Afonso da. Comentário Contextual à Constituição. $9^{a}$ edição, atualizada até a Emenda Constitucional n. 83, de 5.8.2014. São Paulo: Malheiros, 2014. 
1995.

Direito urbanístico brasileiro. $2^{\mathrm{a}}$ ed. rev. atual. São Paulo: Revista dos Tribunais,

SILVA, Virgílio Afonso. Direitos fundamentais: conteúdo essencial, restrições e eficácia. $2^{\mathrm{a}}$ ed. São Paulo: Malheiros, 2011.

SILVA. Vandré Gomes. Uso da avaliação externa por equipes gestoras e profissionais docentes: um estudo em quatro redes de ensino público. Textos FCC, ${ }^{\circ}$ 38. São Paulo: Fundação Carlos Chagas / Superintendência de Educação e Pesquisa, out.2013.

SIMON, Herbert A. Theories of bounded rationality. Decision and organization, v. 1, n. 1, p. $161-176,1972$.

Reason in human affairs, Stanford: Stanford University Press, 1983.

SOCHACZEWSKI, Antonio Claudio. Finanças públicas brasileiras no século XX. In: INSTITUTO BRASILEIRO DE GEOGRAFIA E ESTATÍSTICA - IBGE. Estatísticas do Século XX. Rio de Janeiro: IBGE, p. 357-380, 2006. Disponível em: <https://biblioteca.ibge.gov.br/visualizacao/livros/liv37312.pdf>. Acesso em: 30 set. 2018.

SOUZA, Celina. Estado da arte da pesquisa em políticas públicas. In: HOCHMAN, Gilberto; ARRETCHE, Marta; MARQUES, Eduardo. Políticas públicas no Brasil. Rio de Janeiro: Fiocruz, p. 65-86, 2007

SOUZA, Donado Bello de. Avaliações finais sobre o PNE 2001-2010 e preliminares do PNE 2014-2024. Estudos em Avaliação Educacional, São Paulo, v. 25, n. 59, p. 140-170, set./dez. 2014.

SOUZA, Paulo Renato. Melhoria da educação: um esforço de todos. In: MINISTÉRIO DA EDUCAÇÃO; INEP. Educação para todos: a avaliação da década. Brasília: MEC/INEP, p. 39-52, 2000.

SUCUPIRA, Newton. O ato adicional de 1834 e a descentralização da educação. In: FÁVERO, Osvaldo (org.). A Educação nas constituintes brasileiras. Campinas: Autores Associados, p. 61-73, 2014.

SUNDFELD, Carlos Ari. Direito Administrativo para céticos. $2^{\mathrm{a}}$ ed. rev. ampl. São Paulo: Malheiros; Sociedade Brasileira de Direito Público, 2014.

Fundamentos de direito público. $5^{\text {a }}$ ed. São Paulo: Malheiros, 2010.

TANNO, Claudio Riyudi. EC N⿳95/2016 - Teto de gastos públicos: questões essenciais para o desenvolvimento da educação. Brasília: Câmara dos Deputados; Consultoria de Orçamento e Fiscalização Financeira. Estudo técnico $\mathrm{n}^{\circ}$ 1, 2017. Disponível em: <http://www2.camara.leg.br/orcamento-da-uniao/estudos/2017/et01-2017-teto-de-gastospublicos-questoes-essenciais-para-o-desenvolvimento-da-educacao $>$. Acesso em 21 out. 2018 .

Efeitos da medida cautelar na ADI $n^{0}$ 4917/DF e a frustração de receitas decorrentes da exploração de petróleo destinadas à educação. Brasília: Câmara dos 
Deputados; Consultoria de Orçamento e Fiscalização Financeira. Nota técnica nº 7, 2015. Disponível em: <http://www2.camara.leg.br/orcamento-dauniao/estudos/2015/NT07_2015.pdf>. Acesso em 21 out. 2018.

TANURI, Leonor Maria. História da formação de professores. Revista Brasileira de Educação v. 14, p. 61-88, mai-ago. 2000.

TAPOROSKY, Barbara Cristina Hanauer. O valor anual mínimo por aluno do FUNDEB, o CAQi e a reserva do possível. FINEDUCA-Revista de Financiamento da Educação, v. 6., n. 6, p. 1-16, 2016. Disponível em: 〈https://seer.ufrgs.br/fineduca/article/view/62847>. Acesso em: 29 out. 2018.

TEIXEIRA, Anísio. Plano nacional de educação. Referente aos fundos nacionais de ensino primário, médio e superior. Documenta. Rio de Janeiro, n.8, out. 1962. p.24-31. Disponível em: <http://www.bvanisioteixeira.ufba.br/artigos/plano1.html>. Acesso em 7 set. 2018.

Sobre o problema de como financiar a educação do povo brasileiro: bases para a discussão do financiamento dos sistemas públicos de educação. Revista Brasileira de Estudos Pedagógicos. Rio de Janeiro, v.20, n.52, p.27-42, 1953. Disponível em: <http://www.bvanisioteixeira.ufba.br/>. Acesso em: 4 jan. 2019.

TODOS PELA EDUCAÇÃO. Profissão professor. São Paulo: TPE, Itaú Social, Ibope Inteligência, 2018. Disponível em: <https://www.todospelaeducacao.org.br/_uploads/ _posts/23.pdf?750034822>. Acesso em: 24 nov. 2018.

TOLEDO, Carlos José Teixeira de Toledo. Os pactos de alfabetização: uma análise jurídica de políticas públicas visando à efetivação do direito à educação. Revista da Faculdade de Direito da Universidade São Judas Tadeu, n. 3, p. 174-199, 2015. Disponível em: $\langle$ http://www.usjt.br/revistadireito/numero-3/11-carlos-jose-teixeira-toledo.pdf $>$. Acesso em: 14 out. 2018.

TOMIO, Fabricio Ricardo de Limas. A criação de municípios após a Constituição de 1988. Revista Brasileira de Ciências Sociais v. 17, p. 61-89, 2002.

TORRES, Marcelo Douglas de Figueiredo. Fundamentos de administração pública brasileira. Rio de Janeiro: FGV Editora, 2012.

TRIBUNAL DE CONTAS DA UNIÃO. Relatório e parecer prévio sobre as contas do governo da república - exercício de 2017. Brasília : TCU, 2018.

. Manual básico: aplicação no ensino e as novas regras. São Paulo: TCESP, 2012.

TRIPODI, Zara Figueiredo; SOUSA, Sandra Zákia Lian. A governança em rede na regulação da educação básica mineira: quem governa o quê? Educação em Revista, v. 32, n. 4, 2016.

UNESCO. Declaração Mundial sobre Educação para Todos: satisfação das necessidades básicas de aprendizagem. Jomtien, 1990. Disponível em:

<https://unesdoc.unesco.org/ark:/48223/pf0000086291_por>. Acesso em: 24 out. 2018. 
Documentos del Congreso Internacional "Planeamiento y gestión del desarrollo de la educación". México: UNESCO, 1990. Disponível em: <http://www.unesco.org/education/pdf/11_94_s.pdf>. Acesso em: 7 set. 2018.

OIT. A Recomendação da OIT/UNESCO de 1966 relativa ao Estatuto dos Professores e a Recomendação de 1997 da UNESCO relativa ao Estatuto do Pessoal do Ensino Superior, com um guia de utilização. Unesco/OIT. Viana do Castelo, 2008. Disponível em: <http://unesdoc.unesco.org/images/0016/001604/160495por.pdf.>. Acesso em 4 ago. 2008.

. Las carreras docentes en América Latina: la acción meritocrática para el desarrollo profesional. Santiago: UNESCO, 2015. 53 p. Disponível em: <http://unesdoc.unesco.org/images/0024/002440/244074s.pdf>. Acesso em: 22 nov. 2018.

UNIÃO NACIONAL DOS DIRIGENTES MUNICIPAIS DE EDUCAÇÃO. UNDIME. Undime debate atualização do Piso Salarial do Magistério em grupo de trabalho temporário instituído pelo MEC. 19 abr. 2018. Disponível em: $<$ https://undime.org.br/noticia/19-04-2018-09-47-undime-debate-atualizacao-do-pisosalarial-do-magisterio-em-grupo-de-trabalho-temporario-instituido-pelo-mec $>$. Acesso em: 11 ago. 2018.

URUGUAI, Visconde do; CARVAlHO, José Murilo de (org). Paulino José Soares de Sousa, Visconde do Uruguai. São Paulo, Editora 34, 2002.

VALLE, Vanice Regina Lírio do. Direito fundamental à boa administração e governança. Belo Horizonte: Editora Fórum, 2011.

VAN CREVELD, Martin L. Ascensão e declínio do Estado. São Paulo: Martins Fontes, 2004.

VAZQUEZ, Daniel Arias. Desequilíbrios regionais no financiamento da educação: a política nacional de equidade do FUNDEF. Revista de Sociologia e Política, Curitiba, n. 24, p. 149164 , jun. 2005

VEIGA, Cynthia Greive. História da educação. São Paulo: Ática, 2007.

VELOSO, Juliano Ribeiro Santos. Direito ao planejamento. Editora D'Plácido, 2014.

WEBER, Max, Economia e sociedade: fundamentos da sociologia compreensiva. Tradução de Regis Barbosa e Karen Elsabe Barbosa; Revisão técnica de Gabriel Cohn Brasília: Editora Universidade de Brasília: São Paulo: Imprensa Oficial do Estado de São Paulo, vol. 2, 1999. 